\title{
Evaluation of Critical Materials In Five Additional Advance Design Photovoltaic Cells
}

\author{
S. A. Smith \\ R. L. Watts \\ P. Martin \\ W. E. Gurwell
}

February 1981

Prepared for

The Photovoltaics Division

Solar Energy Research Institute

Contract DS-9-8137-1

under a Related Services Agreement

with the U.S. Department of Energy

Contract DE-AC06-76RLO 1830

Pacific Northwest Laboratory

Operated for the U.S. Department of Energy

by Battelle Memorial Institute 


\section{NOTICE}

This report was prepared as an account of work sponsored by the United States Government. Neither the United States nor the Department of Energy, nor any of their employees, nor any of their contractors, subcontractors, or their employees, makes any warranty, express or implied, or assumes any legal liability or responsibility for the accuracy, completeness or usefulness of any information, apparatus, product or process disclosed, or represents that its use would not infringe privately owned rights.

The views, opinions and conclusions contained in this report are those of the contractor and do not necessarily represent those of the United States Government or the United States Department of Energy.

\section{PACIFIC NORTHWEST LABORATORY}

$$
\text { operated by }
$$

BATTELLE

for the

UNITED STATES DEPARTMENT OF ENERGY

Under Contract DE-AC06-76RLO 1830

$$
\begin{aligned}
& \text { Printed in the United States of America } \\
& \text { Available from } \\
& \text { National Technical Information Service } \\
& \text { United States Department of Commerce } \\
& 5285 \text { Port Royal Road } \\
& \text { Springtield, Virginia } 22151
\end{aligned}
$$

Price: Printed Copy s $\therefore$ Microfiche $\$ 3.00$

NTIS

-Pages Selling Price

$\begin{array}{ll}001-025 & \$ 4.00 \\ 026-050 & \$ 4.50 \\ 051-075 & 55.25 \\ 076-100 & 56.00 \\ 101-125 & 56.50 \\ 126-150 & 57.25 \\ 151-175 & \$ 8.00 \\ 176-200 & 59.00 \\ 201-225 & 59.25 \\ 226-250 & 59.50 \\ 251-275 & 510.75 \\ 276-300 & \$ 17.00\end{array}$


PNL -3710

UC -63

33679000596462

EVALUATION OF CRITICAL MATERIALS IN FIVE ADDITIONAL ADVANCE DESIGN PHOTOVOLTAIC CELLS
S. A. Smith
R. L. Watts
P. Martin
W. E. Gurwe 11

Prepared for

The Photovoltaics Division, Solar Energy Research Institute Contract DS-9-8137-1 under a Related Services Agreement with the U.S. Department of Energy Contract DE-AC06-76RLO 1830

Pacific Northwest Laboratory Richland, Washington 99352 


\section{SUMMARY AND CONCLUSIONS}

This section summarizes the results of the screening of the baseline and sensitivity case advance design photovoltaic cells. The material supply constraints identified in this report are based on the assumption that $25 \mathrm{GW}_{\mathrm{p}}$ of an individual advance design photovoltaic cell are deployed by 2000 (see Chapter 2.0 for a discussion of deployment scenarios). Assuming a slower rate of photovoltaic cell deployment would obviously reduce the severity of the material supply constraints. Our particular deployment scenario was chosen to show type maximum plausible material supply constraints facing photovoltaic cells.

Indium Phosphide/Cadmium Sulfide Backwall Solar Cells may face material availability and cost constraints if $25 \mathrm{GW}_{\mathrm{p}}$ are deployed by 2000 . Most likely adequate supplies of indium will not be available at a reasonable price unless the thickness of the active layer is reduced or the indium lost during planar reactive deposition ( $265 \%)$ is recovered. However, if it is not technically and/or economically feasible to do so, the establishment of long term contracts with indium producers will help reduce future availability problems.

Cadmium sulfide should not provide a major obstacle to the $25 \mathrm{GW}_{\mathrm{p}}$ deployment of this cell if the cadmium sulfide lost during evaporation would be recovered, or if sufficient cadmium sulfide production capacity is developed, either on site or offsite.

Zinc Phosphide MIS Solar Cell can be produced with no serious zinc phosphide supply problems if good materials planning is used. The method used to produce the laboratory quantities of zinc phosphide could easily be scaledup to meet the material needs of deploying $25 \mathrm{GW}_{\mathrm{p}}$ of this cell by 2000 .

Cadmium Telluride Solar Cell could be hampered by cadmium telluride and tellurium supply and cost constraints if $25 \mathrm{GW}_{\mathrm{p}}$ of this cell were deployed by 2000. By minimizing the cadmium telluride active layer thickness, recovering the cadmium telluride lost during evaporation, and increasing the cell conversion efficiency, these supply constraints will be lessened. Also, the tellurium and cadmium telluride needs of photovoltaics should be communicated to the materials industry early and long term contracts should be established. 
World indium supplies may not be sufficient for the indium-tin oxide layer requirements. Work should be directed towards substituting tin oxide for indium-t in oxide in the conductive window layer.

Copper Indium Selenide Solar Cells may encounter serious material supp $7 y$ constraints due to the excessive uses of indium and selenium for 25 GW of these cells. Reduction in active layer thicknesses (to less than 3.3 microns), increases in process and cell conversion efficiencies and the establishment of long term contracts will help minimize these constraints. By communicating the needs of photovoltaics to the selenium producers, work could be initiated on increasing the quantity of selenium recovered from copper anode slimes, and identifying new sources of selenium. Similar tactics should be pursued for indium, however the availability problems are more severe.

Cadmium Selenide Photoelectrochemical Solar Cell baseline case may be deployed on a large scale basis (i.e., $25 \mathrm{GW}_{\mathrm{p}}$ by 2000) if adequate time is allowed for materials planning. Cobalt, cobalt sulfate, indium, indium-tin oxide, and selenium will all present availability problems. Cobalt may also present a constraint in this cell meeting DOE cost goals.

In sensitivity Case 2, graphite was substituted. for cobalt and sulfur in the counter electrode, cadmium-selenide-telluride was substituted for cadmium selenide in the active layer, and tin-oxide was substituted for indium-tin oxide in the transport conducting layer. These changes reduced the materials availability problem to selenium and tellurium. Selenium and tellurium availability problems could be lessened by reducing the active layer thickness, recycling the lost material, communicating selenium and tellurium material requirements to suppliers and establishing long term contracts. 
CONTENTS

SUMMARY AND CONCLUSIONS .

1.0 INTRODUCTION .

2.0 METHODOLOGY AND DEPLOYMENT SCENARIOS USED IN THIS

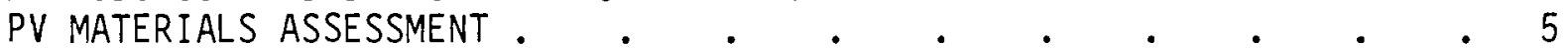

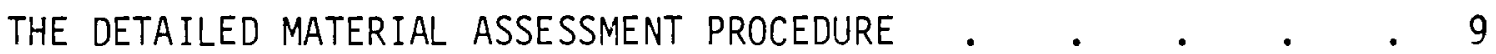

CMAP'S ROLE IN MATERIALS ASSESSMENT $\quad . \quad \cdot \quad \cdot \quad \cdot \quad \cdot \quad \cdot 12$

THE CMAP SCREENING PROCESS . . . . . . . . . . 14

THE CMAP SCREENING DESCRIPTIONS AND THRESHOLD VALUES • • • 14

THE IMPORTANCE OF THE DEPLOYMENT RATE OF A NEW TECHNOLOGY • • 20

PROCEDURE FOR CLASSIFYING CELL MATERIALS $\quad$ • $\quad$ • $\quad$ • $\quad$ • 29

3.0 CELL DESCRIPTIONS AND SCREENING RESULTS . . . . . . • . . 31

INDIUM PHOSPHIDE/CADMIUM SULFIDE (InP/CAS) BACKWALL SOLAR CELL . 32 ZINC PHOSPHIDE MIS SOLAR CELL • . $\quad . \quad . \quad . \quad . \quad . \quad .48$

CADMIUM TELLURIDE SOLAR CELL • • • • .

COPPER INDIUM SELENIDE SOLAR CELL • • • • • • • • • 74

CADMIUM SELENIDE PHOTOELECTROCHEMICAL SOLAR CELL • • • • 88

THE POTENTIAL MATERIAL CONSTRAINTS FOR FIVE CELLS

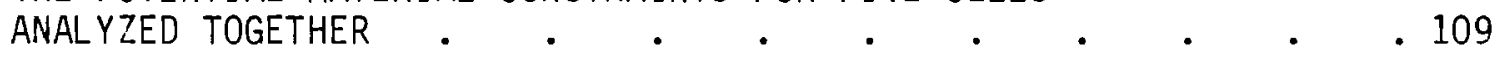

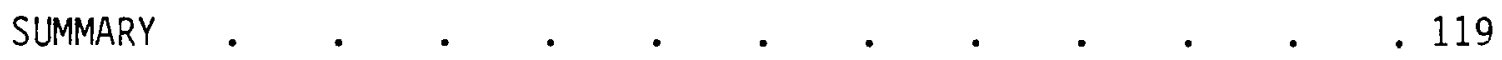

FABR ICATION PROCESS EFFICIENCY AND MATERIAL

RECOVERY DETAILS .

REFERENCES . . . . . . . . . . . . . 123

APPENDIX A . . . . . . . . . . . . . A.1 


\section{FIGURES}

1 The Materials Cycle

2 Typical Conversion Chain or Matrix

3 Overview of the Methodology.

$4 \quad$ Screening System

5 Assessment of Potential Bulk and Raw Materials Problems

6 Projected Usage Levels of a Hypothetical Material With and Without Photovoltaic Usage Showing Rate and Capacity Constraints

7 Material Requirements for 2.5 MW of Annual Cell Production . . . 25

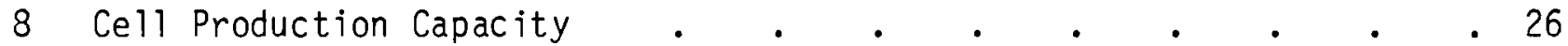

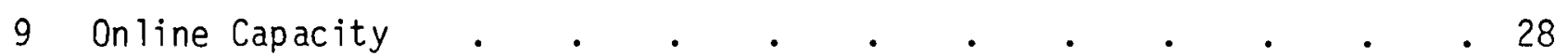

10 The Baseline Indium Phosphide/Cadmium Sulfide

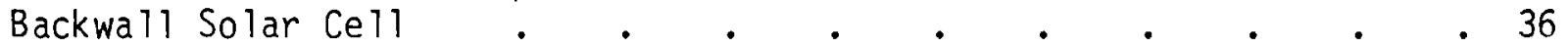

11 Indium Costs Versus Active Layer Thickness and

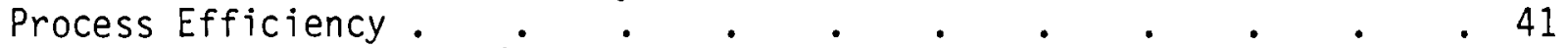

Project Market for Indium with and Without Indium
Phosphide/Cadmium Sulfide Cell Production . $~ . ~$

13 Cadmium Sulfide Layer Thickness and Process Efficiency Versus Maximum Percent of World Cadmium Sulfide Production Consumed in One Year . . . . . . . . . . . 46

14 The Baseline Zinc Phosphide MIS Solar Cell . . . . . . . 49

15 Thickness of the Zinc Phosphide Active and Doped Contact Layers Versus Maximum Percent of World Production Consumed in One Year . . . . . . . . . . . 54

16 The Baseline Cadmium Telluride Backwall Solar Cell . . . . 57

17 CdTe Material Cost as a Function of Layer Thickness, Precursor Form and Purity . . . . . . . . . . . 63

18 Projected Market for Tellurium With and Without CdTe Ce 11 Production 
19 Maximum Share of World Tellurium Consumption Versus CdTe

Layer Thickness and Process Efficiency. . . . • . . 65

20 Projected Market for Indium With and Without Cadmium

Telluride PV Cell Production . . . . . . . . . 69

21 The Baseline Copper-Indium Selenide Cadmium Sulfide

Heterojunction Solar Cell . . . . . . . . . 75

22 Indium Present Costs Versus Active Layer Thickness

and Coevaporation Process Efficiency . . . . . . 80

23 Projected Market for Indium With and Without Copper

Indium Selenide PV Cell Production . . . . . . . 81

24 Copper Indium Selenide Layer Thickness and Process

Efficiency versus Maximum Percent of World Selenium

Production Consumed in One Year . . . . . . . 83

25 Total Cadmium Sulfide Layer Thickness and Process

Efficiency versus Maximum Percent of Wor ld Cadmium

Sulfide Production Consumed in One Year . . . . . . 87

26 The Baseline Cadmium Selenide Photoelectrochemical

Solar Cell . . . . . . . . . . . . . 89

27 Cobalt Present Cost Versus the Thickness of the

Cobalt Sulfide Counter Electrode . . . . . . . . 95

28 Total Encapsulant Layer Thickness and Soda Lime

Glass Present Costs . . . . . . . . . . . . . 98

29 Selenium Requirement as a Function of Process,

Process Efficiency, and CdSe Layer Thickness . . . . 100

30 Projected Market for Selenium as a Function of

Process, Process Efficiency and CdSe Layer Thickness . . . . 101

31 Selenium Requirement as a Function of Process,

Process Efficiency, and $\mathrm{CdSe}_{0.65} \mathrm{Te}_{0.35}$ Layer Thickness . . . 103

32 Projected Market for Selenium as a Function of Process,

Process Efficiency, and CdSe $0.65 \mathrm{Te}_{0.35}$ Layer Thickness . 104

33 Tellurium Requirement as a Function of Process, Process Efficiency, and $\mathrm{CdSe}_{0.65} \mathrm{Te}_{0.35}$ Layer Thickness . . . 105

34 Projected Market for Tellerium as a Function of Process, Process Efficiency, and $\mathrm{CdSe}_{0.65} \mathrm{Te}_{0.35}$ Layer Thickness 


\section{$\underline{\text { TABLES }}$}

1 Ce 11 Production Capacity and Cumulative Production for 1990-2000 in GW

2 Consequences of Alternative Deployment Scenarios . . . . . 28

3 Chemical Conversion Ratios . . . . . . . . . . . 33

4 Process Efficiencies Assumed for Baseline Cases . . . . . . 34

5 Bulk Material Requirements for: Indium Phosphide/ Cadmium Sulfide Backwall Solar Baseline . . . . . . 37

6 "B" Material Net Import Reliance and Major Foreign Sources . . . 48

7 Bulk Material Requirements for: Zinc Phosphate MIS Solar Cell Baseline . $. \quad . \quad . \quad . \quad . \quad . \quad . \quad .51$

8 "B" Material Net Import Reliance and Major Foreign Sources . . . 55

9 Bulk Material Requirements for: Cadmium Telluride Backwall Solar Cell Baseline. . . . . . . . . 59

10 Bulk Material Requirements for: Copper-Indium Selenide/ Cadmium Sulfide Heterojunction Baseline . . . . . 77

11 Projected U.S. Selenium Consumption By End Use . . . . . 84

12 Bulk Material Requirements for: Cadmium Selenide

13 Bulk Material Summary Report . . . . . . . . . . 110

14 "A" Materials . . . . . . . . . . . . . 112

15 "B" Bulk Materials . . . . . . . . . . . . . . 116

16 Mixed Scenario "A" Bulk Materials . . . . . . . . . . 117 


\subsection{INTRODUCTION}

The objective of this study is to identify potential material supply constraints due to the large-scale deployment of five advanced photovoltaic (PV) cell designs, and to suggest strategies to reduce the impacts of these production capacity limitations and potential future material shortages. Some PV technologies supported by the Photovoltaic Research and Development program of the Solar Energy Research Institute (SERI) use materials which are potentially in short supply or are high in cost. These technologies may never achieve large-scale commercialization unless supplies of these critical materials are increased or their cost of production is reduced. In the past, such situations have been encountered and new sources and production processes have been developed through deliberate, planned programs for managing the supply problem.

Material supply shortages occur either because: (1) the production capacity cannot cope with a sudden increase in demand for the material, or (2) the known sources for the supply are inadequate. The former problem can be averted if it is recognized early enough. Large capacity increases for many materials can require 10 to 20 years to achieve. Hence, early identification of potential shortages is required for timely planning and development of increased production. A radical example of sharply increased production capacity is the a luminum industry during World War II. The second kind of problem has also been successfully dealt with in the past. An instance is the nuclear industry, where many new sources of uranium were discovered as a result of deliberate programs to find and develop new resources. The mining and materials processing industries have an excellent record of successfully meeting new challenges to sharply increase supplies of unusual materials. Again, careful assessment of all potential suppiy sources is a necessary predecessor to the larger task of exploration and development of such sources. Besides adequate supplies, PV cell researchers need to know whether the materials are or will be affordable. The price of increased supplies for some photovoltaic materials may limit the ultimate size of a potential market application.

Materials availability studies are thus a necessary complement to the mainstream research and development. A unique tool is available for systematically 
reviewing PV technologies and the material supply chain to see it potential supply constraints may exist. This tool, the Critical Materials Assessment Program (CMAP), screens the designs and their supply chains and identifies potential shortages which might preclude large-scale use of the technologies. Then a review of the critical materials identified in the computer screening takes place, and options for coping with or mitigating the supply problems are presented.

Previous research (Watts et al. 1980) evaluated the potential material supply constraints due to the large scale deployment of the five following advanced design photovoltaic cells:

- polycrystalline silicon

- amorphous silicon

- cadmium sulfide/copper sulfide frontwall

- polycrystalline gallium arsenide MIS

- advanced concentrator - $500 x$

This report presents the result of the screening of the five additional advanced PV cell designs:

- indium phosphide/cadmium sulfide

- zinc phosphide

- cadmium telluride/cadmium sulfide

- copper indium selenium

- cadmium selenide photoelectrochemical

Each of these five cells is screened individually assuming that they first come online in 1991, and that 25 Gwe of peak capacity is online by the year 2000. (These individual cases are referred to as the "baseline cases" in this report.) A second computer screening assumes that each cell first comes online in 1991 and that each cell has a 5 GWe of peak capacity by the year 2000, so that the total online capacity for the five cells is 25 GWe. (This case is referred to as the "mixed scenario".)

Based on a review of the preliminary baseline screening results, suggestions were made for varying such parameters as the layer thickness, cell production processes, etc. The resulting PV cell characterizations were then 
screened again by the CMAP computer code. (These cases are referred to as the "sensitivity cases".)

Chapter 2 describes the CMAP methodology used to identify critical materials. Chapter 3 of this report provides detailed characterizations of the advanced photovoltaic cell designs under investigation, descriptions of additional cell production processes (Watts et al. 1979), and the results of this investigation. 


\subsection{METHODOLOGY AND DEPLOYMENT SCENARIOS USED IN THIS PV MATERIALS ASSESSMENT}

Modern industrial society rests on the continuation of adequate supplies of goods and services which require the operation of a massive industrial complex supported by a continuous supply of ores and renewable resources from the earth (see Figure 1). This supply chain is a complex one involving thousands of factories and mines. The key question addressed in this methodology is whether a given new PV technology will be supported in the future by an adequate industrial supply chain at an affordable price. The emphasis for this report is: "Will adequate supplies of quality PV materials be available and affordable?"

The answer to this question requires a different approach from the type usually taken in resource or strategic materials studies. Typically, the emphasis is on the supply situation for only raw materials. In this study the attitude is taken that supply constraints could arise anyplace in the material stream. Another key concept in the study is that we are less concerned about materials (the scarcity of gold, for instance) in general than whether or not it will be possible to obtain and afford the gold to build the needed photovoltaic cells, assuming a given production process.

In order to approach these problems it is necessary to characterize: (1) the final product desired, (2) the production process used to produce the product, (3) the materials processing stream, and (4) the available renewable and non-renewable resources (see Figure 2). The product and its production are unique to a specific product assessment. The materials processing streams and the characterization of the materials sources have many common elements with the data used to assess other designs and even technologies. Thus, the specific cell material needs are analyzed (starting with the cell itself) and the material streams are tracked back to raw materials, as is illustrated in Figure 2. During the tracking process the needs of PV are compared to normal industry capacity to see if production pinch points are likely and whether the materials are likely to be affordable for the desired cell production.

In order to make this comparison with normal industry capacity it is necessary to also know the desired rate and timing of installations of the new 
THE MATERIALS CYCLE

or

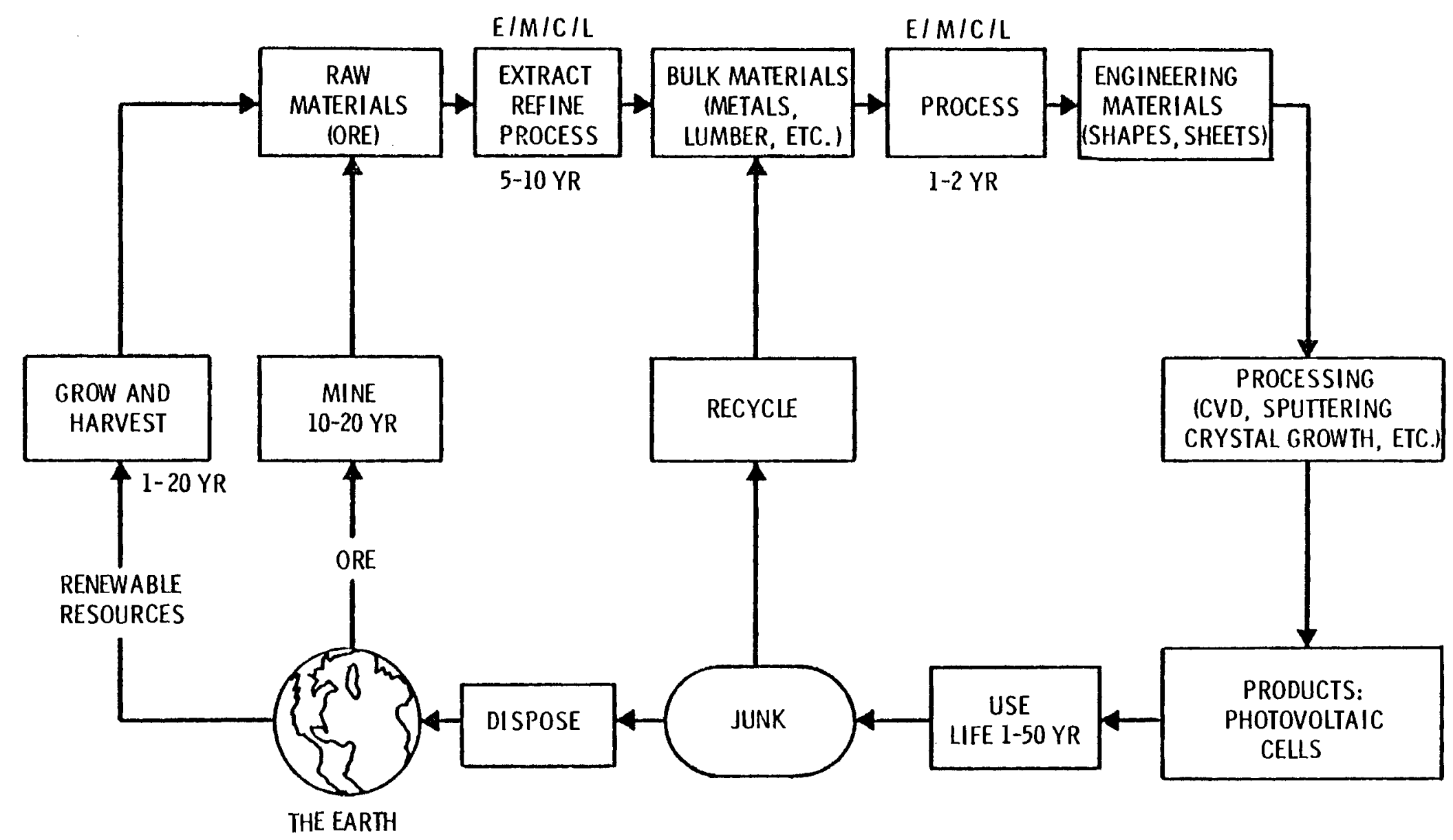

TIME TO INCREASE CAPAS,ITY

E/M/L/C - ENERGY, MATERIAL, LABOR, CAPITAL INPUTS

FIGURE 1. The llaterials Cycle 


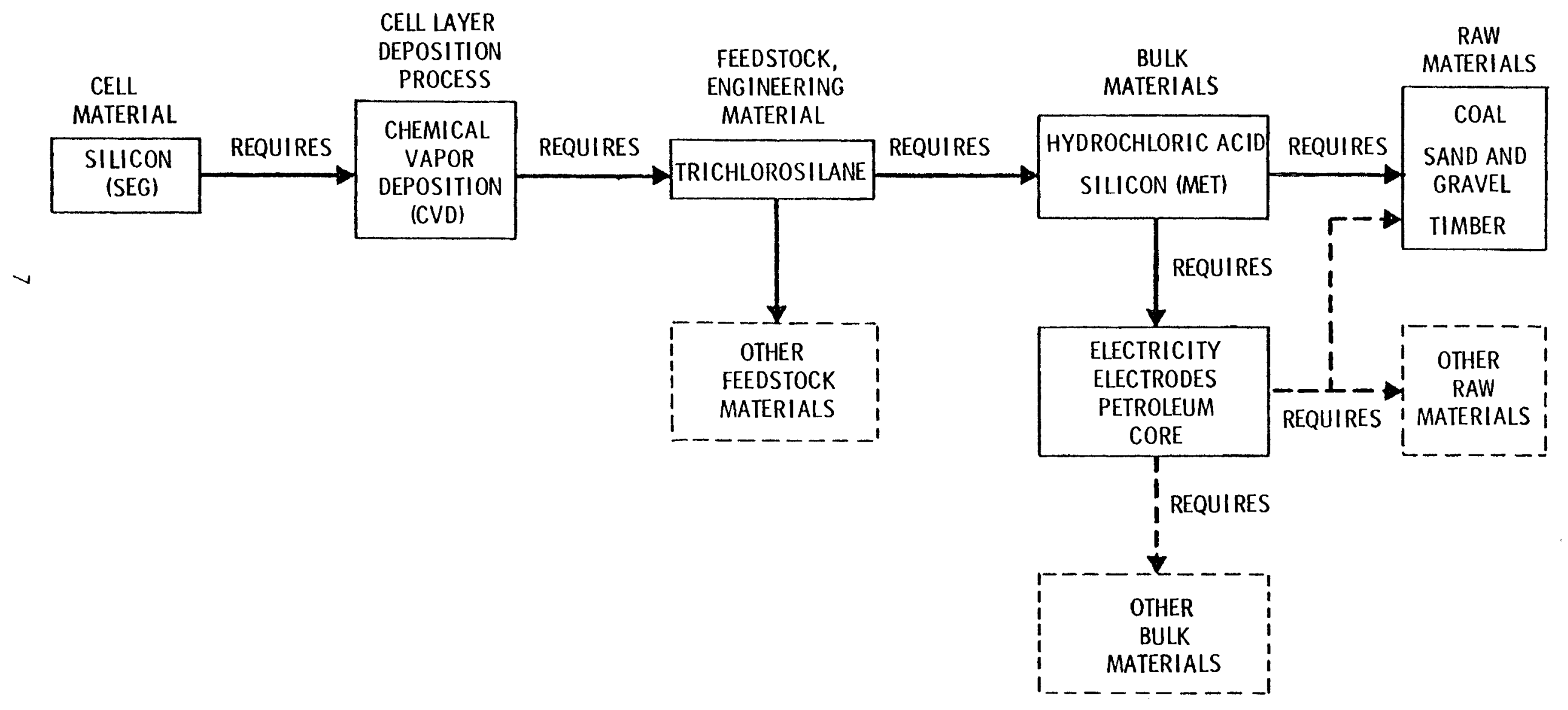

FIGURE 2. Typical Conversion Chain or llatrix 
technology. There are practical limitations to the amount of change a given industry can accomodate without a disruption of the normal market. The prevention of such disruptions is precisely the end objective of this analysis. Mitigating strategies can be developed to minimize the impact of potential constraints on availability and prices.

Tracking the material stream from the desired end product back through industrial and material production processes to identify potential constraints is not a rigorous, definitive process because of the dynamic nature of industrial processes and because there are many alternative pathways through the intermeshing material streams. In practice, it is usually satisfactory to identify the constraints in well known material flows.

One would normally think of tracking materials from the mine to final use. The opposite procedure is used in this materials assessment. Figure 2 illustrates this process. The cell materials, one of which can be silicon, must be deposited on previous layers of the cell. The process illustrates chemical vapor deposition (CVD) using a feedstock (or engineering material), in this case, trichlorosilane.

The CVD process, of course, requires other feedstocks to make a complete cell but these are omitted for clarity in Figure 2. The production of trichlorosilane requires "bulk material" (hydrochloric acid and metallurgical grade silicon) for its manufacture but these, in turn, require both raw materials and yet other bulk materials in their manufacture. The "bulk materials", electrodes, electricity, and coke require yet other bulk materials and raw materials for their manufacture ad infinitum. Fortunately, this process can be truncated after a reasonable number of iterations without significant error for our purposes.

Tracking of material streams can introduce a great deal of arithmetic into the assessment process and leads to the need for mechanizing the tracking process. This has been done in a computer program: Critical Materials Assessment Program (CMAP).

The following sections of this chapter describe the material assessment process in greater detail and show how it is used to identify potential 
material problems. The sections contain:

- The detailed procedure used in making a materials assessment

- A discussion of the part CMAP plays in the materials assessment

- A description of the CMAP screening results

- A discussion of the descriptions used in CMAP to discriminate potential supply and price problems including typical threshold values for these descriptions

- A discussion of the effects of technology deployment rates on the materials supply streams

- A discussion of the methods used to evaluate the potential problems identified by CMAP

\section{THE DETAILED MATERIAL ASSESSMENT PROCEDURE}

When the simplified example (Figure 2) is expanded to an overall materials assessment of an entire technology, the problem becomes much more complex, involving large numbers of materials and production processes. The analys is required can best be described as consisting of the following nine basic steps (refer also to Figure 3 ):

Step 1. Identify Materials Requirements

The final construction materials (such as brass, concrete, composites, and trichlorosilane) for a technology under study are identified, preferably at the component or subsystem level. This results in a listing of the quantities of all materials required for the construction and installation of one system "unit" (such as one polycrystalline silicon cell) producing a specified amount of energy.

Step 2. Identify Process of Producing Cells

The process of producing the cell will have characteristic or typical material use efficiencies and these will affect the amount of feedstock materials required in producing cells for a given energy production. 


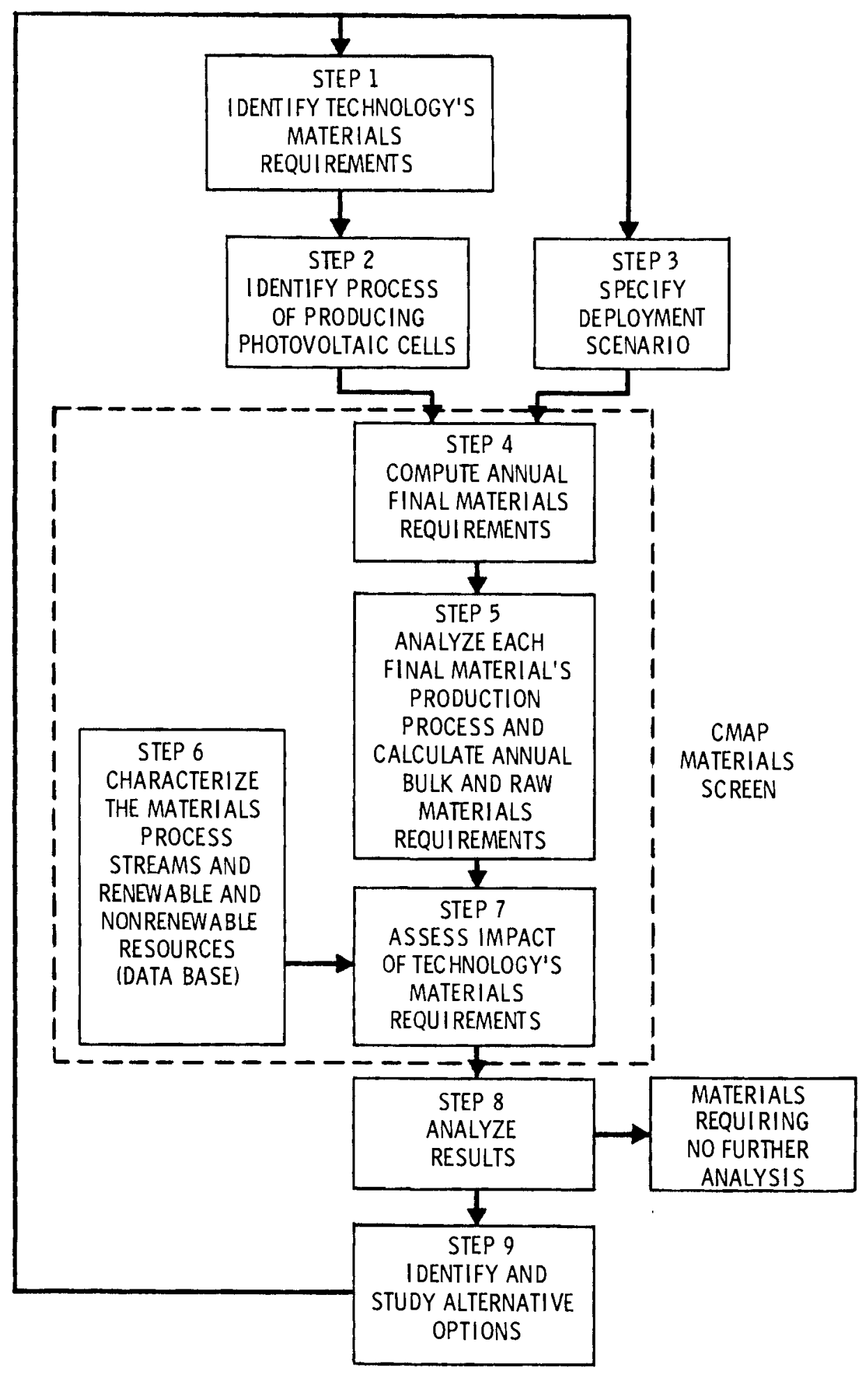

FIGURE 3. Overview of the Methodology 


\section{Step 3. Specify Deployment Scenario}

The scenario for a technology describes the annual and cumulative production of units over a specified period of time. (Production and deployment of units are assumed equivalent.)

Step 4. Compute Annual Materials Requirements

The annual materials requirements are calculated by multiplying the units per year by the quantities of each final material in one unit.

Step 5. Analyze Material Production Processes

Each final construction material is produced from bulk and secondary bulk materials (such as copper, cement, graphite, fiber, or sulfuric acid) and raw materials (such as sand and gravel, ore, or timber). Quantities of all such materials are calculated by year.

Step 6. Characterize the Materials Industry

For all materials, a data base is developed. It includes such factors as availability, source, production capacity, expected growth in demand, and prices on a domestic and worldwide basis for each material.

Step 7. Assess the Technology's Impact

The technology's annual demand for each material (as determined in Steps 1 to 4) is compared to pertinent information in the data base for that material. This reveals the impacts of the system, expressed in such terms as percentage of total production required, percentage of resources consumed, or dependency on imports.

Step 8. Analyze the Results

The significance of each impact identified in Step 6 is assessed by comparison to a predetermined threshold value. Some impacts will be of no concern; others will require further study.

Step 9. Study Alternative Options or Mitigating Strategies

For those materials involving significant uncertainties, or potential constraints, alternative options are identified and studied. One option is 
materials substitutions. If this is considered, Steps 1 through 7 are repeated to evaluate the effect of the substitution. Other options open to managers and planners for reducing uncertainties include redesigning a component, subsystem, or an entire system; undertaking R\&D aimed at alleviating an uncertainty; exploring for new resources; or developing incentives for expanding manufacturing capacity.

\section{CMAP'S ROLE IN MATERIALS ASSESSMENT}

The computer algorithm, Critical Materials Assessment Program (CMAP), was specifically developed to aid in the overall materials assessment process by mechanizing Steps 4 through 7, as shown in Figure 3 and discussed in the previous section.

Thus, the analys is program is known as the Critical Materials Assessment Program (CMAP) and its functions are those enclosed by the dashed line in Figure 3. CMAP can accumulate all requirements for a given material regardless of the ultimate usage of that material in a system. It can give the bulk and raw constituents of a material; calculate the impacts of a system's materials requirements relative to worldwide availability, source, demand, etc.; screen out materials that are of no concern; and identify those that are of concern. It uses threshold values of pertinent ratios to make this discrimination.

These values are discussed in a subsequent section about the descriptions used to indicate potential problems.

The CMAP data base currently contains about 2000 data entries (covering hundreds of materials) developed from over a hundred information sources (see Appendix A). The sources include many government publications, technical handbooks, special reports, technical papers, trade association and technical association data, journal articles and the like. Where no secondary source data are available, information has been obtained directly from producers. All data entries are referenced for further examination when necessary.

In short, the methodology contains a data base on most of the materials information planners and designers of systems will need, and the means for rapidly compiling the information toward the desired result. Information on 
materials which is not already contained in the data base is easily added as additional studies are carried out for which they are required. This information then becomes part of the data base and is available to subsequent users.

CMAP does not do a materials assessment. What it does is to carry out a screening for potential problem areas using stored data and threshold values for the criteria. The screening results from the computer (see the following section) are printed out for analysis by knowledgeable individuals who analyze and interpret the results.

One of the reasons this is so important is that the key descriptions used in the screening process do not have convenient, universal levels at which they become important. An example follows.

One of the descriptions (or parameters) of interest for bulk material screening in CMAP is the production growth rate required to meet the demand of PV cells and all other industries (retrievable from the materials data base). The threshold value for this parameter is currently set at $10 \%$ per year. Thus, if the required growth rate exceeds $10 \%$ a flag is set on the printout signifying that a potential production capacity problem exists. If the material in question has a relatively small production base (e.g., hydrogen sulfide, $99.999 \%)$, then a $10 \%$ growth rate might not be difficult to achieve. However, if the material in question already has a large production base (e.g., aluminum) then a 10\% growth rate would represent an enormous requirement for additional capital, labor, facilities, etc., and a definite problem exists.

Thus, in reality, an accurate "threshold value" for a given parameter might be different for each material considered. Any attempt to incorporate this reality into CMAP would make the automated screening intractable and defeat its entire purpose. Therefore, a single threshold value is postulated for each parameter -- a value, based on Battelle's experience, that is representative and generally conservative for the majority of materials. These threshold values are not intended to be absolute measures of material criticality, but merely indicators that can speed and simplify the analysis of results. The responsibility for accurately interpreting those results properly remains the task of the experienced analyst. 
THE CMAP SCREENING PROCESS

CMAP performs three principal functions: (1) calculation of total materials requirements; (2) determination (for each material) of a set of parameters that characterize the materials' demand impact; and (3) comparison of the parameter values so determined with certain "threshold" values for those parameters, which, when exceeded, triggers "flags" on the output printout that call attention to the potential problem.

Figure 4 depicts CMAP program operation. To facilitate and increase the flexibility of analyses, CMAP has been made interactive. This means that input data can be changed while cases are being examined. Thus, the top blocks of user-supplied impact can be changed to analyze desired case variations (e.g., different deployment scenarios) and/or to iterate based on results. The bottom left blocks contain the baseline system design characterization (material requirements) and the materials data base are entered by card deck. These data cannot be changed interactively, but can be updated periodically as needed.

Calculation of materials requirements begins with a technology materials 1ist. Total amounts of the materials on that list required to support a specified deployment scenario are calculated (based on the number of units required). Then, using information stored in the materials data base, production processes required to produce those materials are analyzed to determine secondary bulk material and raw material requirements.

Once total materials demand has been established, attention turns to the material parameters and threshold values on which the screening is based. Since the parameters of interest and threshold values differ somewhat for bulk and raw materials, the screening of these two types of materials is done separately (separate printouts are produced), and the screening threshold values are, of course, discussed separately in the following section.

\section{THE CMAP SCREENING DESCRIPTIONS AND THRESHOLD VALUES}

Bulk Materials Screening Parameters and thresholds

The parameters of interest for bulk materials are listed below. These parameters are determined for each material required. 


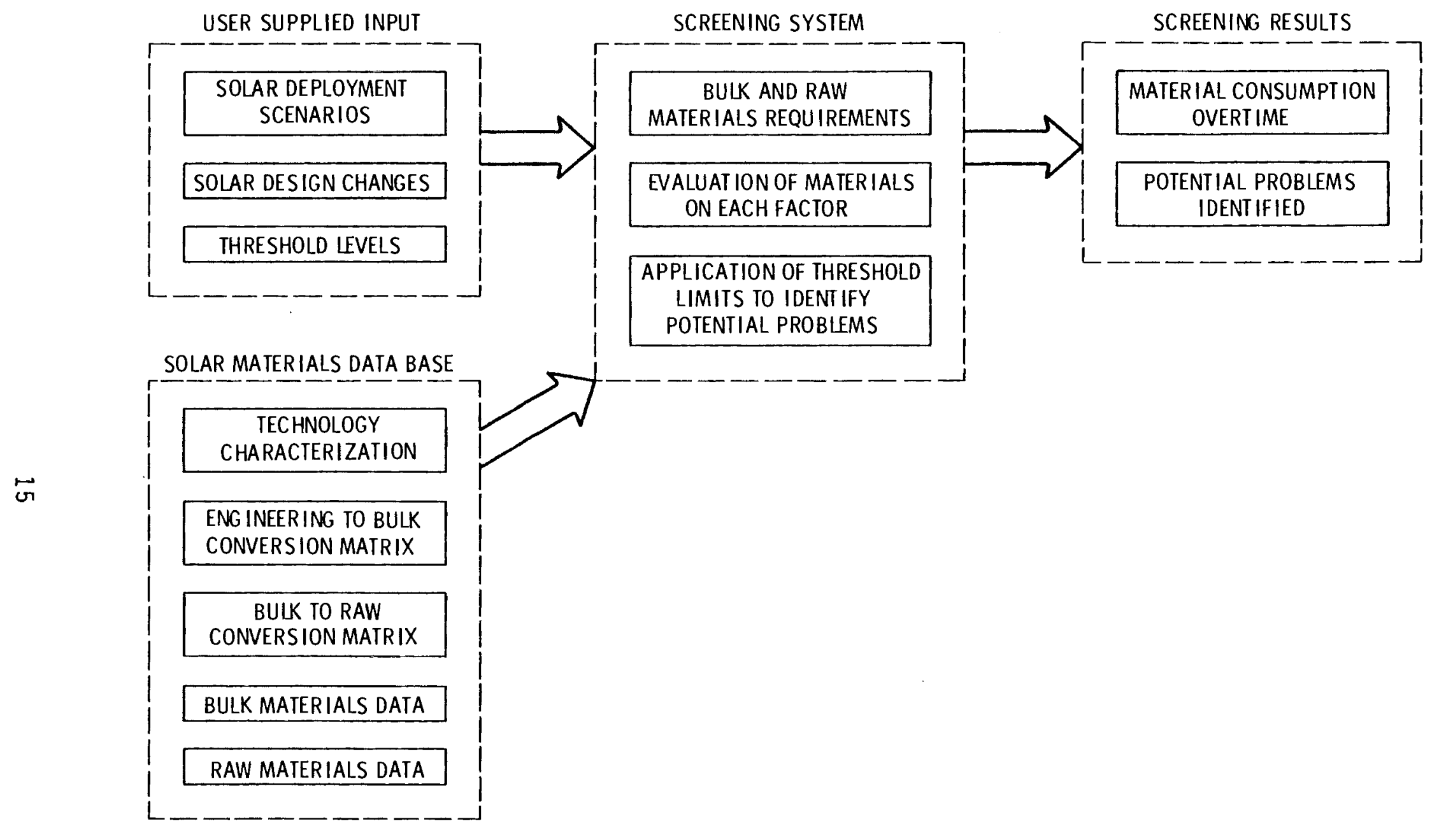

FIGURE 4. Screening System 
- Percent of the material which is produced as a byproduct of another material production process

- Maximum production growth rate required to meet solar and nonsolar material needs (This occurs between 1990 and 1991 for our deployment scenario.)

- Maximum percent demand of solar as a portion of total world demand

- Current percent of the world production attributable to a single foreign source

- Current material purchase cost contribution to solar power installed, $\$ / \mathrm{kW}$

- Current net percent of U.S. material consumption that is imported (from all foreign sources).

In the following paragraphs these parameters are discussed, the rationale for assessing criticality is developed, and currently used threshold values are identified.

Percent Supplied as Byproduct

The threshold value is set here at 50 percent. The frequent implication that byproduct dependence is constraining is often misleading. Materials sometimes considered today as byproducts may be viewed at other times as coproducts or even primary products depending upon supply/demand and market/price conditions. Hence, the term "byproduct material" should not necessarily be viewed as a "low-cost" or an "undesirable" material production consequence of a process stream. The economics of many extractive and manufacturing processes are highly dependent upon byproduct/coproduct recovery. That economic dependence or leverage frequently becomes important in assessing criticality of the material. However, where economic dependence is not present, only strong demand and attractive market prices will bring forth the capital investment required to recover the amounts of the byproduct material needed.

Growing demand for the primary product is of basic importance to sustaining given levels of byproduct production. If the technology requirements for the byproduct material are sma11, or if the market is "glutted", even declining primary material production levels can maintain adequate byproduct supplies. 
World Production Growth Rate

The threshold value here is 10 percent. Many small volume or new materials can readily maintain a 10 percent annual rate of growth. However, large volume, capital-intensive comodities would have great difficulty in sustaining such a growth rate.

Maximum Percent Technology Demand, One Year World

This threshold is set at 10 percent. This figure represents the technology's market impact on material consumption at its potentially highest demand level relative to demand for that material for other uses. At high percentage of demand levels, the technology demand can be a market driver, perhaps bringing about higher prices or even a cartel. This criterion may also be viewed as a trigger for close examination of opportunity costs -- that is, the technology's potential for adverse impact on other segments of the economy demanding the same material.

Percent From One Nation, Non-U.S.

This threshold level is set at 35 percent. It represents a measure of supply domination in world markets by any one non-U.S. nation. If the technology material demand is also a significant proportion of total demand, then potential for supply disruption or the development of a cartel is present. The nature of the material demand, as well as the dominant nation identified, then becomes a part of the criticality judgment. This criterion usually assumes more importance in assessing raw materials, since bulk material production among industrial nations tends to disperse over time.

Present Costs in $\$ / \mathrm{kW}$

This threshold is set at $\$ 50.00$ per $k W$ of constructed capacity. This value is calculated as MT required $/ \mathrm{kW}$ cells $\times \$$ per MT. Values for material in excess of the $\$ 50.00$ threshold deserve close examination. It should be emphasized that these figures represent present bulk material cost -- not the cost of the fabrication processes. The fabrication cost of cells can very substantially exceed the materials cost per se. Stated costs also are representative of the prevailing art for producing the materials -- often in low 
volumes in the case of new materials. For many newer materials, those production costs can be expected to be lowered over time.

Total cost of the cells attributable to these materials becomes sensitive to changes in price or required volume of the materials in question. Materials price forecasts, fabrication cost determinations, design review and possible materials substitutions might be considered.

\section{Net Percent Imported}

The threshold value is set at 50 percent and is based on current levels of net U.S. imports. If the maximum volume of material required by the technology is very small compared to total U.S. demand in the same time frame, there is probably little cause for concern regardless of the U.S. import level. For many materials -- particularly raw materials -- for which the U.S. is dependent on imports, that dependency is likely to grow in future years. This is a matter of general economic concern and not necessarily related to any specific technology under consideration. In other words, we would be concerned on ly if the technology and its deployment scenario might substantially exacerbate an already recognized U.S. import dependency for certain materials.

Raw Materials Screening Parameters and Thresholds

With respect to the screening of raw materials, levels of current reserves and resources estimates are introduced as screening parameters, in addition to those identified in the bulk material discussion. In general, where the U.S. is reserve/resource deficient, it is also import dependent. The focus of concern in these cases is levels of world reserves and resources and whether the system construction would substantially contribute to world resource deficiency or to substantially greater U.S. import dependency. The complete list of raw material screening parameters is given below.

- Average world production growth rate (per year) required to meet solar and al1 other projected demands

- Maximum percent demand (in any given year) of solar as a portion of total wor ld demand

- Percent of U.S. reserves consumed by photovoltaics and all other projected demand 
- Percent of U.S. resources consumed by photovoltaics and all other projected demand

- Percent of world reserves consumed by photovoltaics and all other projected demand

- Percent of world resources consumed by photovoltaics and all other projected demand

- Current percent of the world production attributable to a single foreign source

- Current material purchase cost contribution to photovoltaic power installed, $\$ / \mathrm{kW}$

- Current net percent of U.S. material consumption that is imported (from all foreign sources).

The previous discussions of parameters under "Bulk Materials Screening" adequately describe those parameters which are common to both bulk and raw materials. Therefore, most of those discussions will not be repeated here. However, "World Production Growth Rate", and "Percent From One Nation, NonU.S.", where the raw material threshold value is different is discussed. The two parameters that change and the new parameters, U.S. and world reserve and resources, are discussed below.

World Production Growth Rate

The threshold value here is 7 percent rather than the 10 percent value used for bulk materials. Extractive operations usually require longer lead times and are very capital-intensive. Sustained annual growth rates of 5 percent are not too unusual, but 7 percent could be.

Percent From One Nation, Non-U.S.

The threshold value here is 60 percent rather than the 35 percent value used for bulk materials. Developed resources tend to be more concentrated in specific locations than bulk material production facilities. However, the opportunity to exploit undeveloped resources in alternative locations generally exists. Consequently, the higher threshold value is used. 


\section{U.S. Reserves and Resources Consumed and World Reserves and Resources}

Consumed

The threshold values used are 400 percent, 300 percent, 300 percent, and 200 percent, respectively. For the 10-year time span considered, those threshold values are quite conservative. One could argue for many materials that they might even comfortably be doubled. In analyzing U.S. reserves and resources, sensitivity to doubling those values would be minimal, since we are usually either highly foreign source dependent or hardly at all.

\section{Screening Process}

CMAP screening consists of comparison of screening parameter values for each material with the parameter threshold values. CMAP asks whether or not the threshold value has been exceeded, and, if it has, sets a flag on the printout identifying the potential problem. The required logic is illustrated in Figure 5 for bulk and raw materials.

\section{THE IMPORTANCE OF THE DEPLOYMENT RATE OF A NEW TECHNOLOGY}

New technologies bring changes to the materials supply industry. It is one of the important roles of CMAP to focus attention on potential material supply stresses caused by a planned rate of deployment for a new technology. New technologies tend to start out slowly because of initial conservatism of customers and of the supply chain. This conservatism tends to protect the materials industry from rapid, large-scale changes in demand for key materials.

Geopolitics and national needs may, however, produce stronger forces tending toward more rapid shifts in demand and these changes may produce severe dislocations in the materials supply industry. These more rapid changes can be accommodated more easily if problems are recognized ahead of time and dealt with by longer term strategies.

The photovoltaic program is a program capable of developing some of these material stress points because of two factors: (1) geopolitics is causing petroleum supplies to become expensive and undependable, and (2) very rapid 


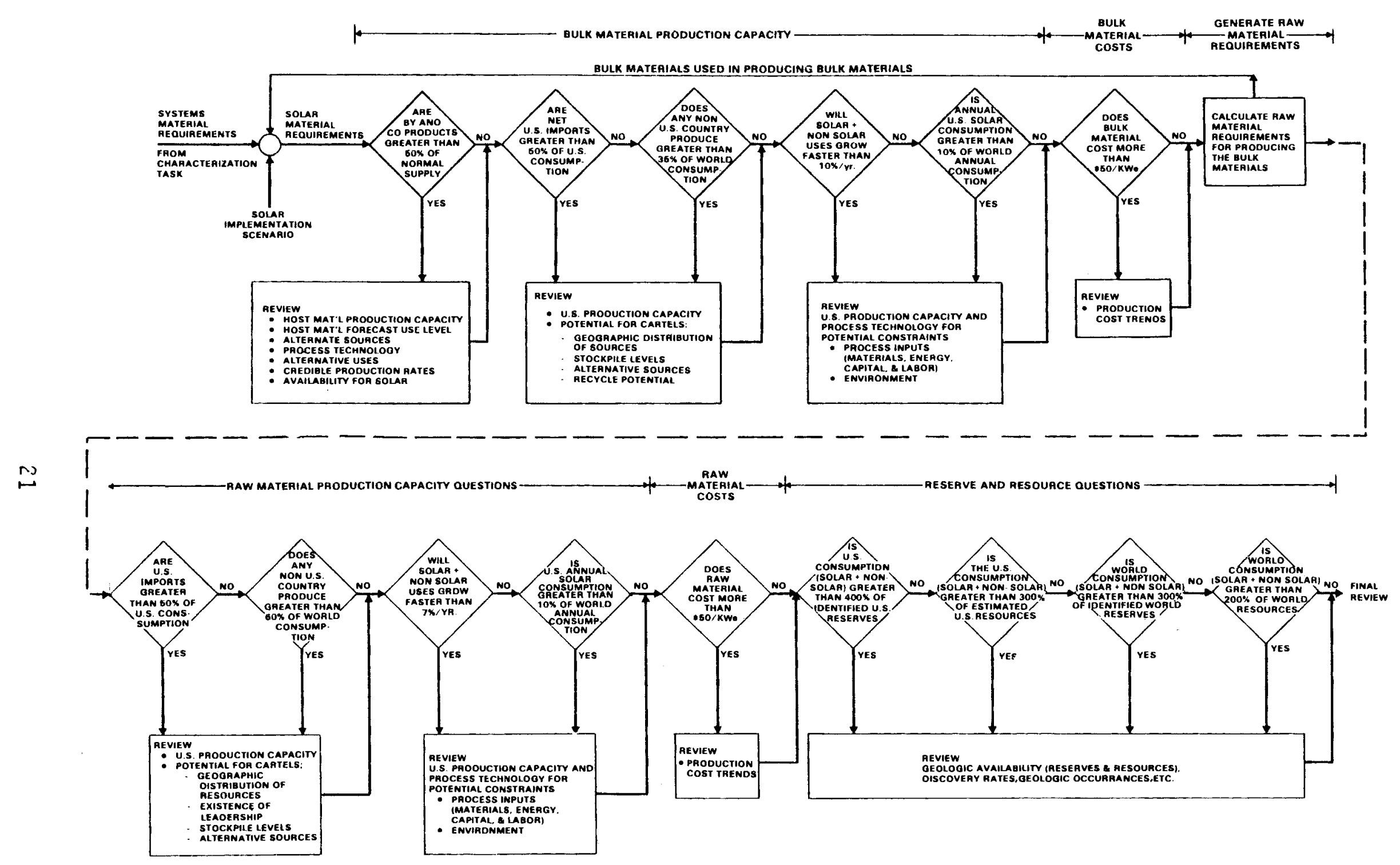

FIGURE 5. Assessment of Potential Bulk and Raw Materials Problems 
progress is occurring in the development of higher efficiency, lower cost devices.

The Domestic Policy Review (DPR) of Solar Energy ${ }^{(1)}$ gives one assessment of how fast this might occur. The DPR provides information on the amount of fuel displaced by various solar technologies now and in the year 2000 . For photovoltaics the estimates for 2000 are:

\begin{tabular}{|c|c|c|c|}
\hline & Base Case & $\begin{array}{c}\text { Maximum } \\
\text { Practical } \\
\end{array}$ & $\begin{array}{c}\text { Technical } \\
\text { Limit } \\
\end{array}$ \\
\hline Quads displaced in the year 2000 & .1 & 1.0 & 2.5 \\
\hline $\begin{array}{l}\text { KWh generated at } 1,000 \text { Btu/kWh } \\
\text { Power, peak generating capacity } \\
\text { on line in } 2000 \text {, assuming } 20 \% \\
\text { being the ratio of output power }\end{array}$ & $10^{10}$ & $10^{11}$ & $2.5 \times 10^{11}$ \\
\hline to peak operating capacity & $5.7 \mathrm{GW}$ & $57 \mathrm{GW}$ & $142 \mathrm{GW}$ \\
\hline
\end{tabular}

This particular study assumes that considerable capacity of silicon cells is online by the year 2000 and that $25 \mathrm{GW}$ is supplied by advanced ce 11 designs. It is also assumed that the advanced photovolatic cells do not come online before 1990. This assumption places some interesting constraints on the manner by which 25 GW of advanced cells are placed online.

Two types of stress can be placed on the materials supply industry; one is, of course, the rate at which facilities for processing have to be expanded; the second type is encountered for materials which are byproducts of other industries where there is a practical limit to the quantity of byproduct materials which can be produced. Both types of constraints are encountered in this study and are presented in Figure 6. The bottom curve illustrates the projected values of material usage without the new deployment of the PV cells. The dotted line just above this curve represents a $10 \%$ increase in capacity for the industry. The highest dotted line represents the limit placed on the byproduct because of its dependency on the production of primary material. The 


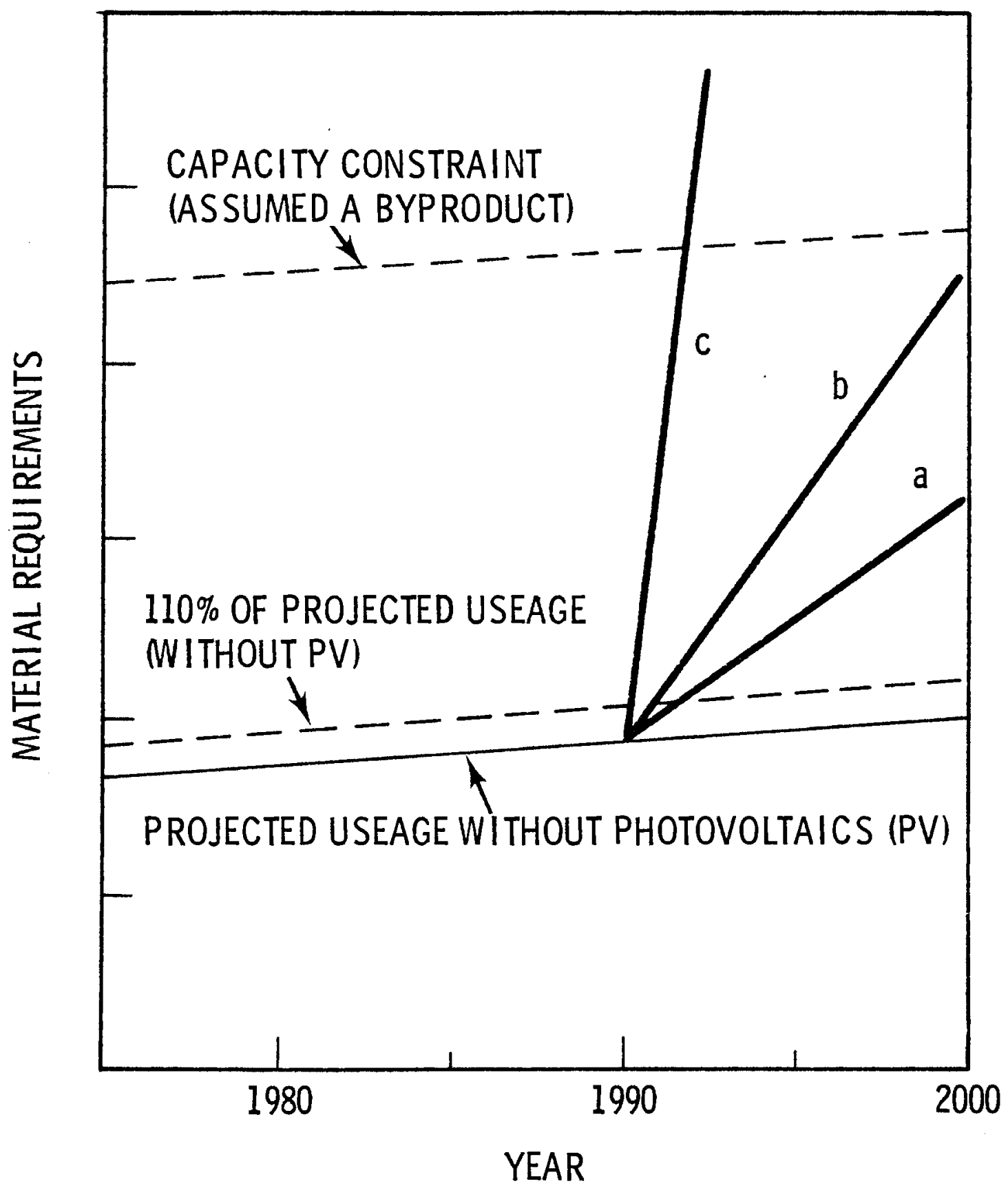

FIGURE 6. Projected Usage Levels of a Hypothetical Material With and Without Photovoltaic Usage Showing Rate and Capacity Constraints 
curves a, b, and c beginning at 1990, represent different usage levels of the byproduct in various designs and total usage (including both PV and non-PV uses).

Curve "a" exceeds the $110 \%$ production curve but its shape is such that is does not exceed $10 \%$ increase in any one year so that it does not create the rate of increased stress that would be encountered if curve "b" were followed. This curve exceeds the $10 \%$ criteria in the first year. Curve "b" represents a case where ultimate capacity could be handled but where special strategies may be required to assure quality and delivery at an affordable price.

Curve " $c$ ", on the other hand, represents a situation which calls for the development of new sources of material in addition to special strategies to assure quality, delivery and price.

Scenario \#1

Production scenarios can be varied to help one or the other, but not likely both, of these constraints. The minimum stress on ultimate capacity results from the assumption that all PV cell manufacturing plants are (for our example) online in 1990 and produce 2.5 MW for 10 years (see Figure 7). This approach, however, maximizes the rate stress because it places an instantaneous demand on the materials market to support the $2.5 \mathrm{MW}$ production facility. This scenario would be highly unlikely because it takes skilled engineers and contractors to build material production and cell production plants. It would be outrageously expensive to create and then almost immediately fold up a plant construction and process equipment manufacturing industry.

Scenario \#2

A more realistic approach is to assume that capacity to fabricate cells is added linearly each year starting January 1, 1990 and assuming that plant construction continues to January 1, 2000. The online capacity to produce cells is thus assumed to be as shown in Figure 8 . The area under this curve can be assumed to be the cumulative online cell capacity (assuming no failures) and for this study has been adjusted to equal $25 \mathrm{GW}$ by the end of the year 2000 . This means that 4.545 GW of cell fabrication will take place in the year 2000. This is shown in Table 1 for convenience. 


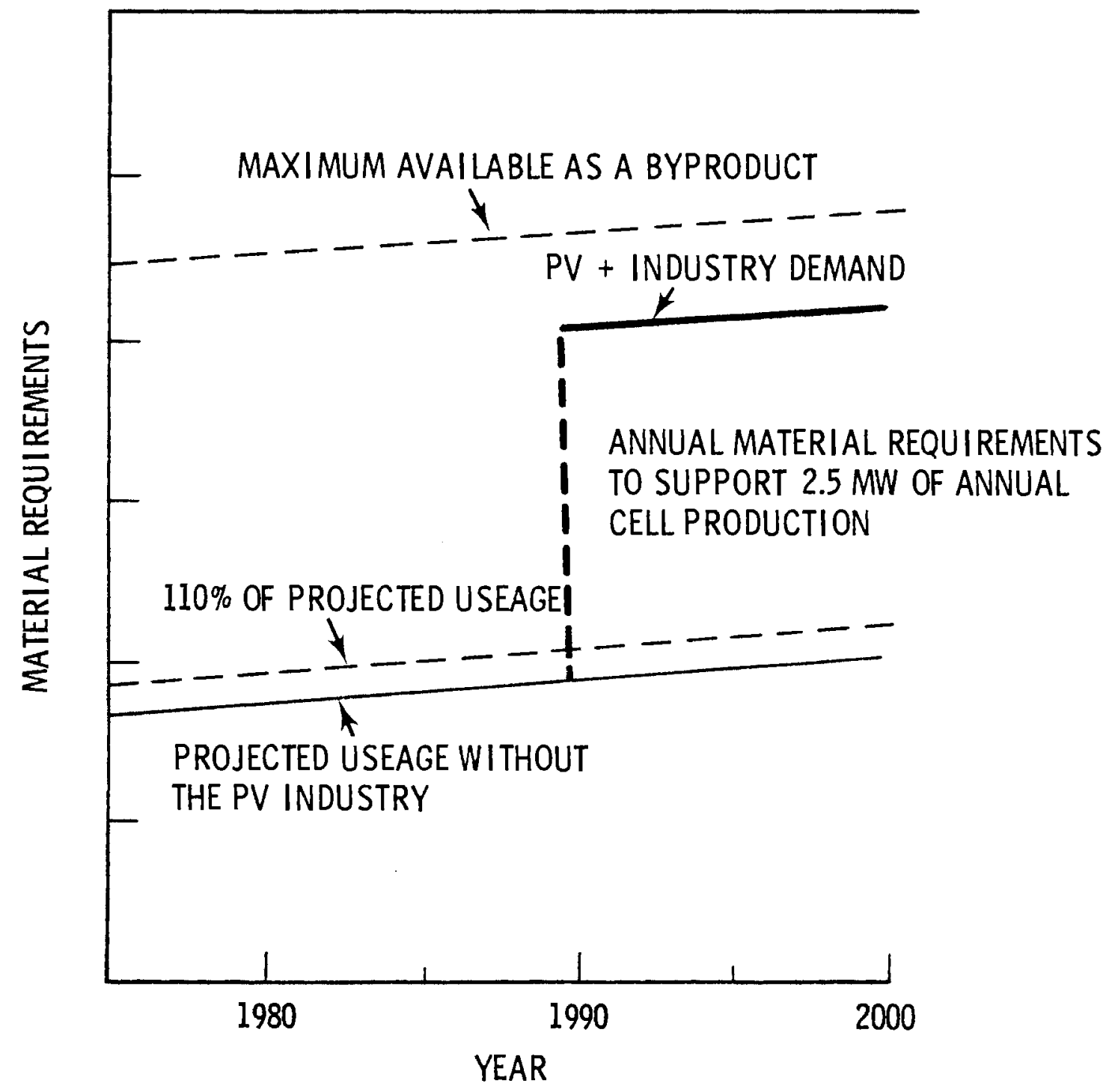

FIGURE 7. Material Requirements for 2.5 MW of Annual Cell Production 


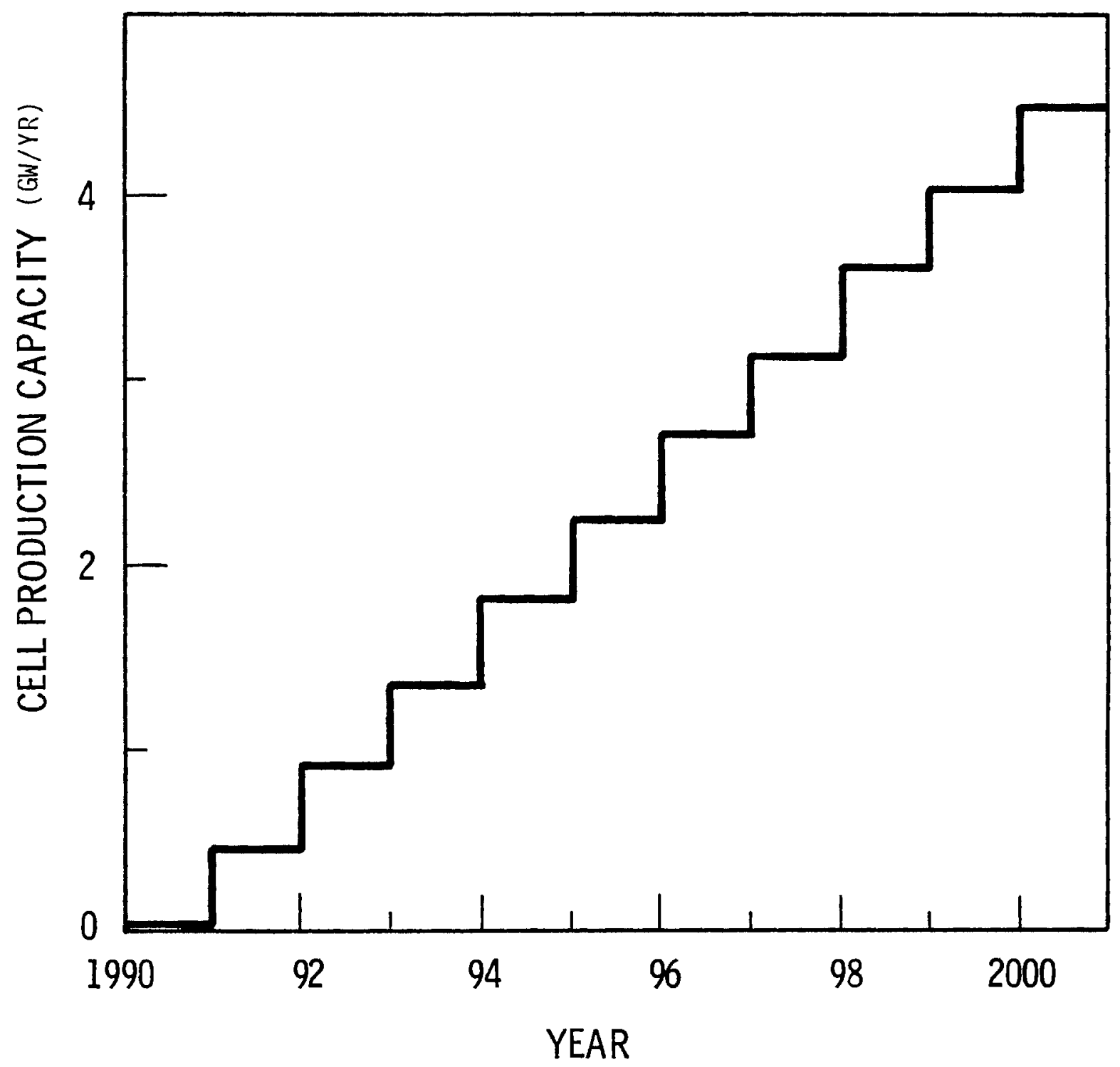

FIGURE 8. Cell Production Capacity 
TABLE 1. Ce11 Production Capacity and Cumulative Production for 1990-2000 in GW

$\begin{array}{cccc}\text { Year } & \begin{array}{c}\text { Cell Production } \\ \text { Capacity Added/Yr. }\end{array} & \begin{array}{c}\text { Cells } \\ \text { Produced } / Y_{r} .\end{array} & \begin{array}{c}\text { Cells Producing } \\ \text { Electricity, Total }\end{array} \\ 1990 & 0.4545 & 0 & 0 \\ 1991 & 0.4545 & 0.4545 & 0.4545 \\ 1992 & 0.4545 & 0.9091 & 1.3636 \\ 1993 & 0.4545 & 1.3636 & 2.7272 \\ 1994 & 0.4545 & 1.8182 & 4.5454 \\ 1995 & 0.4545 & 2.2727 & 6.8181 \\ 1996 & 0.4545 & 2.7273 & 9.5454 \\ 1997 & 0.4545 & 3.1818 & 12.7272 \\ 1998 & 0.4545 & 3.6364 & 16.3636 \\ 1999 & 0.4545 & 4.0909 & 20.4545 \\ 2000 & 0.4545 & 4.5455 & 25.0000\end{array}$

This set of assumed production values places $18.18 \%$ of the total 10 year production online in the year 2000. This is, of course, the largest material requirement for any year. The cases analyzed in this study all use this distribution of values.

Scenario \#3

From the viewpoint of building plants, one could consider an alternative case, where each year the ability to build cell production plants is linearly increased. This is a way of reducing the pressure on process equipment manufacturers who would otherwise have to come to full production the first year for the previous example. This latter assumption also reduces the pressure on the materials supply industries in early years but increases it in the later years of the period being studied (see Figure 9). This scenario was rejected because of the severe pressure $\mathrm{placed}$ on the materials industry in the later years.

This results in a maximum of about $27 \%$ of all PV cells being built in the last year. For this particular scenario (25 GW on line in 2000) this amounts to $6.75 \mathrm{GW}$ going on line in the last year. 


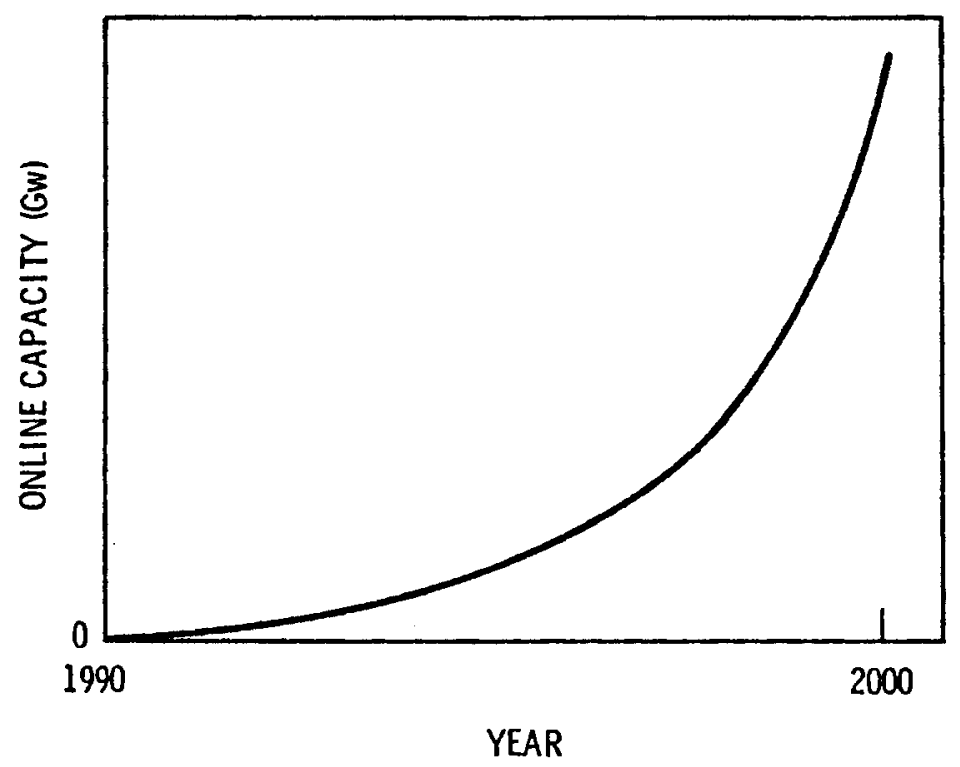

FIGURE 9. Online Capacity

The following table compares the consequences of the three deployment pathways described above.

TABLE 2. Consequences of Alternative Deployment Scenarios

Deployment Path

Constant Ce 11 Production

Constant Cel1 Capacity Addition

(Used in this study)

Constant Additional Construction

Capability to Increase Production
Maximum Ce 11 Production $\mathrm{GW} / \mathrm{Yr}$

2.5

4.54

6.75
$\%$ of $25 \mathrm{GW}$ in Maximum Year

$10 \%$

$18 \%$

$27 \%$

The next step in identifying potential material supply constraints is to analyze the computer screening results and to classify the materials. This procedure is discussed in the following section. 
PROCEDURE FOR CLASSIFYING CELL MATERIALS

After the CMAP (computer program) has screened the photovoltaic cells it prints out the results in a form convenient for review. The manual review of screening results consider all materials which exceed any threshold even though many will not present any serious problems for the implementation of PV based on the desired deployment scenario.

This manual review process emphasizes the various data items concurrently to determine whether the material is economically important to the PV cell production or whether the PV level of usage is likely to be high enough to produce stresses in the material market. Based on this manual review of the CMAP results, materials are classified as "A", "B" or "C" materials.

An "A" material is a material that requires further investigation (beyond the computer analysis) to determine availability and/or cost constraints. Flags raised by the computer under the headings of "Max. \% System 1 Year World" and "Present cost in $\$ / \mathrm{kW}$ " usually indicate a problem worthy of future review.

A "B" material usually exceeds at least one threshold level, but is used in small quantities or at low costs. These materials should be reassessed in the future since some could become problems due to design changes, etc.

A "C" material does not exceed any of the threshold levels and is not now expected to present future materials constraints. 


\subsection{CELL DESCRIPTIONS AND SCREENING RESULTS}

The following five advanced photovoltaic cell designs were screened for critical materials using the CMAP computer code:

- Indium Phosphide/Cadmium Sulfide Backwal1

- Cadmium Telluride Backwall

- Zinc Phosphide MIS

- Cadmium Selen ide Photoelectrochemical

- Copper-Indium Selenide/Cadmium Sulfide

A brief description of the five baseline cells ${ }^{(a)}$ is presented in this chapter, along with the changes made for the sensitivity analys is.

Also, the results of the CMAP computer screening are evaluated, concentrating on the "A" and "B" materials. The "A" materials are evaluated to determine whether or not the future availability of these materials at a reasonable price will be a problem. Mitigating strategies are suggested to help alleviate "A" material availability and cost problems.

Specific mitigating strategies are not recommended for "B" materials since they are not expected to pose serious availability problems to photovoltaics. However, all "B" materials should be reassessed in the future in case their status changes.

The results presented in this Chapter are based upon a $25 \mathrm{GW}_{\mathrm{p}}$ deployment scenario as described in Chapter 2.0. The probability of one of these advance design photovoltaic cells (or photovoltaic cells in general) being deployed on this scale depends upon their technical and economic feasibility. This deployment scenario was chosen to illustrate the maximum plausible material constraints. It assumes that 1) the photovoltaic technology meets the DOE cost goals' and 2) a particular thin film technology becomes predominant. If these two assumptions become reality and a particular advanced design photovoltaic is deployed on a large scale (i.e., $25 \mathrm{GW}_{\mathrm{p}}$ by 2000) the following material

(a) Baseline cell characterizations were developed with the assistance of the SERI Photovoltaic Division. 
supply constraints may arise. If a less aggressive deployment scenario were chosen, the severity of the material supply constraints would be reduced.

The quantity of material in a cell layer required to generate $1 \mathrm{GW}_{\mathrm{p}}$ under AM1 insolation $\left(1 \mathrm{~kW} / \mathrm{m}^{2}=\mathrm{GW} / \mathrm{km}^{2}\right)$ was calculated using the layer thickness, material density and the cell efficiency. Grid contacts were assumed to cover $10 \%$ of the cell area. In the discussion of each cell a figure is included which describes the baseline cell. The probable range of layer thicknesses expected for these cells once they reach the commercialization stage are shown in the schematic drawings. A single "most likely" thickness was chosen from the range with assistance from and the approval of SERI PV Division technical staff. These "most likely" thicknesses were used to determine the material requirements for the baseline cases.

The tabular data below the cell illustration figure gives the material contained in each layer in metric tons per GW $\mathrm{G}_{\mathrm{p}}$. The corresponding amount of chemical feedstock required to deposit the layer of material can be calculated by dividing the quantity of material in the layer by the processs efficiency and the chemical ratio. Chemical ratios are defined and 1 isted in Table 3 . Process efficiencies assumed for the baseline cases are given in Table 4 . In this program, the feedstock quantities are computer calculated as part of the computerized screening process.

\section{INDIUM PHOSPHIDE/CADMIUM SULFIDE (InP/CdS) BACKWALL SOLAR CELL}

\section{Cell Description}

The InP/CdS structure presently under study is the backwall shown schematically in Figure 10. The top layer is 1-20 $\mathrm{mm}$ of CdS, evaporated from bulk CdS onto ITO (0.1-0.4 $\mathrm{\mu m})$ coated soda lime glass. The CdS layer is then annealed in $\mathrm{H}_{2} \mathrm{~S}$ to enlarge grain size. Using In and $\mathrm{PH}_{3}$ (and a $5 \% \mathrm{Be}-95 \% \mathrm{Al}$ alloy dopant) in the planar reactive deposition process, a $1-5 \mu \mathrm{m}$ thick InP layer is grown epitaxially on the CdS. Beryllium doping of InP is graded from concentrations of $\sim 10^{16}-10^{17} / \mathrm{cm}^{3}$ near the CdS layer to concentrations of $\sim 10^{19}$. $/ \mathrm{cm}^{3}$ at back contact. Doping lowers the sheet resistance of the InP layer and is necessary in forming an ohmic contact with the back metal layer. The 
IABLE 3. Chemical Conversion Ratios

\begin{tabular}{|c|c|c|c|c|}
\hline \multicolumn{2}{|l|}{ Feedstock } & \multirow{2}{*}{$\begin{array}{c}\begin{array}{c}\text { Chemical } \\
\text { Ratio* }\end{array} \\
.207\end{array}$} & \multicolumn{2}{|r|}{ Material Deposited } \\
\hline Trichlorosilane & $-\mathrm{SiHCl}_{3}$ & & Si & - Silicon \\
\hline Phosphine & $-\mathrm{PH}_{3}$ & .911 & $P$ & - Phosphorous \\
\hline Diborane & $-\mathrm{B}_{2} \mathrm{H}_{6}$ & .781 & B & - Boron \\
\hline Silane & $-\mathrm{SiH}_{4}$ & .874 & $\mathrm{Si}$ & - Silicon \\
\hline Cuprous Chloride & $-\mathrm{Cu}_{2} \mathrm{Cl}_{2}$ & .804 & $\mathrm{Cu}_{2} \mathrm{~S}$ & - Cuprous Sulfide \\
\hline Zinc Borofluoride & $-\operatorname{Zn}\left(B F_{4}\right)_{2}$ & .274 & $\mathrm{Zn}$ & - Zinc \\
\hline Trimethyl Gallium & $-\mathrm{Ga}\left(\mathrm{CH}_{3}\right)_{3}$ & .607 & Ga & - Gallium \\
\hline Trimethyl Indium & $-\operatorname{In}\left(\mathrm{CH}_{3}\right)_{3}$ & .718 & In & - Indium \\
\hline Trimethyl Aluminum & $-\mathrm{Al}\left(\mathrm{CH}_{3}\right)_{3}$ & .374 & A1 & - Aluminum \\
\hline Arsine & $-\mathrm{AsH}_{3}$ & .961 & As & - Arsenic \\
\hline Germane & $-\mathrm{GeH}_{4}$ & .947 & $\mathrm{Ge}$ & - Germanium \\
\hline Hydrogen Sulfide & $-\mathrm{H}_{2} \mathrm{~S}$ & .941 & S & - Sulfur \\
\hline Tantalum & $-\mathrm{Ta}$ & 1.220 & $\mathrm{Ta}_{2} \mathrm{O}_{5}$ & - Tantalum Pentoxide \\
\hline Titanium & $-\mathrm{Ti}$ & 1.670 & $\mathrm{TiO}_{2}$ & - Titanium Dioxide \\
\hline Acetylene & $-\mathrm{C}_{2} \mathrm{H}_{2}$ & .923 & c & - Carbon \\
\hline Indium Chloride & $-\mathrm{InCl}_{2}$ & .618 & In & - Indium \\
\hline Tin Chloride & $-\mathrm{ShCl}_{4}$ & .456 & Sn & - Tin \\
\hline Cupric Chloride & $-\mathrm{CuCl}_{2}$ & .473 & $\mathrm{Cu}$ & - Copper \\
\hline Indium Chloride & $-\mathrm{InCl}_{2}$ & .618 & In & - Indium \\
\hline Selenium Dioxide & $-\mathrm{SeO}_{2}$ & .712 & $\mathrm{Se}$ & - Selenium \\
\hline Thiourea & $-\mathrm{SC}\left(\mathrm{NH}_{2}\right)_{2}$ & .421 & S & - Sulfur \\
\hline Cadmium Chloride & $-\mathrm{CdCl}_{2}$ & .613 & $\mathrm{Cd}$ & - Cadmium \\
\hline Cobalt Sulfate & $-\mathrm{CoSO}_{4}$ & .380 & Co & - Cobalt \\
\hline
\end{tabular}
*Chemical Ratio = MT of material deposited per MT of feedstock at $100 \%$ process ef-
ficiency. 
TABLE 4. Process Efficiencies Assumed for Baseline Cases

\section{Process}

Chemical Spraying

Chemical Vapor Deposition (CVD)

Cuprous Ion Hot Dipping

Electroless Plating

Electroplating

Energy Beam Deposition

Evaporation

Glow Discharge Decomposition

Liquid Phase Epitaxy (LPE)

Metal Organic Chemical Vapor Deposition (MO-CVD)

Molecular Beam Epitaxy (MBE)

Solder Dipping

Sputtering

Screen Printing, Brush Technique, Painting

Planar Reactive Evaporation (PRE)

Close-Spaced Vapor Transport (CSVT)

Plasma Deposition
Assumed Efficiency*

$20 \%$
$35 \%$
$10 \%$
$90 \%$
$80 \%$
$45 \%$
$35 \%$
$10 \%$
$95 \%$
$30 \%$
$55 \%$
$90 \%$
$40 \%$
$80 \%$
In $/ 30 \%$ for $P$
$70 \%$
$35 \%$

*Process Efficiency = amount deposited/amount contained in the feedstock (precursor) Where masks are used in vapor depos-ting grid contacts, the efficiency is reduced by a factor of 10 , i.e., cell area coverage, no recovery from mask.

A cell packing factor of 0.8 is assumed and included in the above figures. 
back contact is $\sim 500 \AA$ of evaporated $\mathrm{Zn}$. This layer can also be Au coated $\mathrm{Zn}$ $(100 \mathrm{~A} / 400 \mathrm{~A})$, both of which are evaporated. Using ITO as starting material, the ITO window layer can be sputtered or e-beam evaporated or, using solutions of $\mathrm{InCl}_{2}$ and $\mathrm{SnCl}_{4}$, can be chemically sprayed onto glass support substrates. A $02 \mu \mathrm{m} \mathrm{SnO} \mathrm{S}_{2}$ layer deposited with an evaporated $\mathrm{Al}$ grid is an acceptable substitute for the conducting ITO window layer. $\mathrm{SnO}_{2}$ is evaporated or sputtered using bulk $\mathrm{SnO}_{2}$, deposited by CVD processes using either $\mathrm{SnCl}_{4}$ or $\mathrm{Sn}\left(\mathrm{CH}_{3}\right)_{4}$ with $\mathrm{O}_{2}$, or sprayed using solutions containing $\mathrm{SnCl}_{4}$.

Figure 10 displays the InP/CdS cell structure and materials used in each layer, including alternate materials. For simplicity, representative deposition processes and associated feedstock materials are shown in conjunction with a range of process efficiencies considered typical for each process. State-ofthe-art InP/CdS solar cells employ layer thicknesses designated as "most likely". Planar reactive deposition process is discussed in a later section while all other processes have been discussed elsewhere (R. L. Watts et al., 1979). A $10 \%$ cell conversion efficiency was assumed for the baseline InP/CdS cel1.

\title{
Screening Results
}

Review of the CMAP screening of the baseline (see Table 5) and sensitivity indium phosphide/cadmium sulfide solar cells identified the following "A" materials:

\author{
Baseline \\ Indium \\ Phosphine 99.999 \\ Indium - tin oxide \\ Cadmi um Sulfide \\ Sensitivity Case 1: $15 \%$ cell conversion efficiency \\ Ind ium \\ Phosphine 99.999 \\ Indium - tin oxide \\ Cadmium Sulfide
}




\section{InP/CdS SOLAR CELLS}

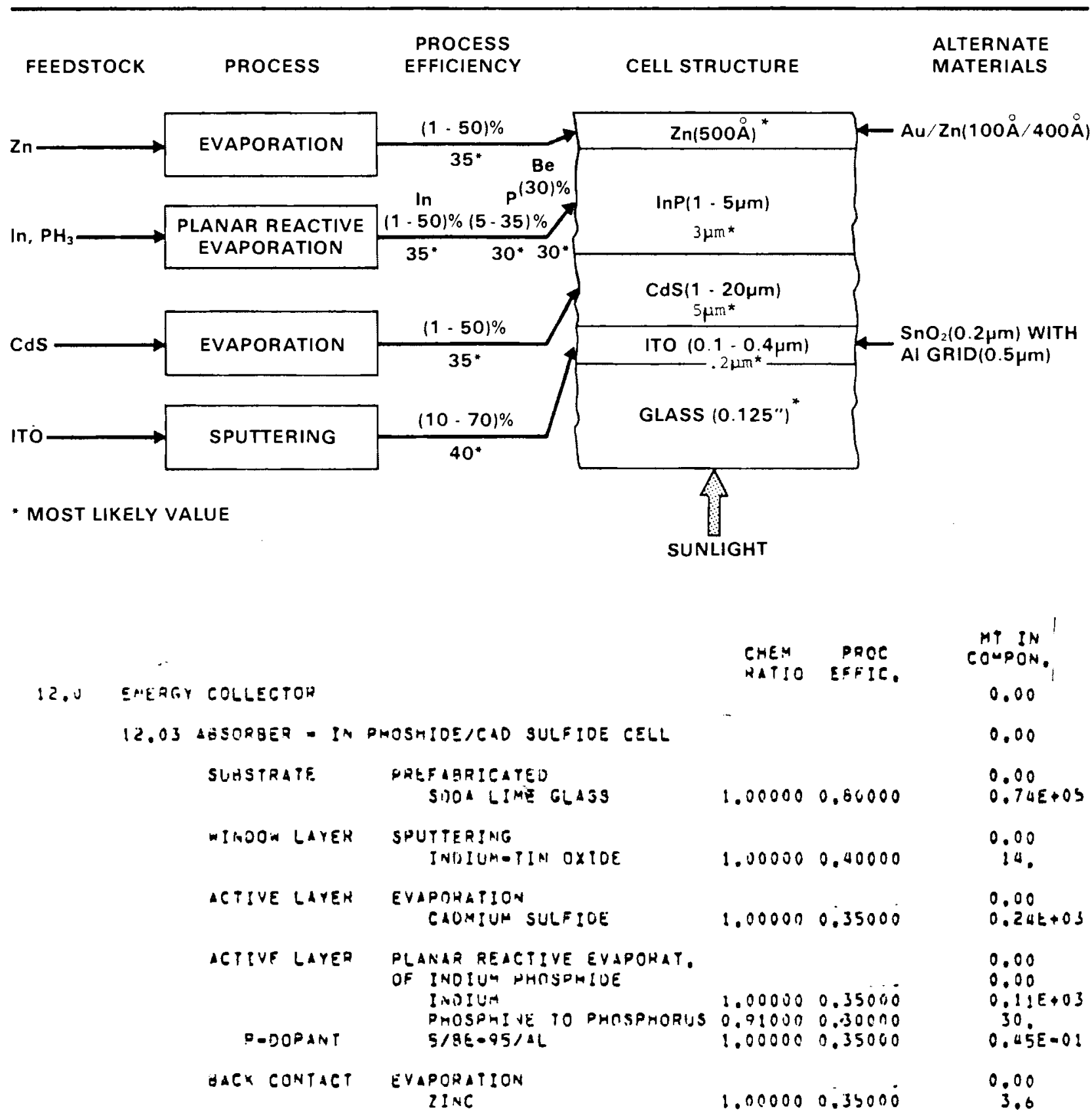

FIGURE 10. The Baseline Indium Phosphide/Cadmium Sulfide Backwall Solar Cell 
TABLE 5. Bu7k Material Requirements for: Indium Phosphide/ Cadmium Sulfide Backwall Solar Baseline

SOLAH SCENARIC: INIRTOUCTION YEAR: 1901

CUMULATIVE CAOACITY $2000-$ 25. HOH

FACInas

THRESHOTQ LEVELS--

ALUMINUM

HEQYLLIUM
CADMIIIA

COKE

PETRDLEUA COME

GLASS. SODD LIMF.

ELECIRICITY (KWH)

INI) IUM

LIME

MAGNESIUM

FEYRDMANGANESE

DXYGEN, LISUIO

PHOSPMHRLUS

NITRIC ACIO

SULFUR

SULFURIC $\triangle$ TIO

TIN

WIIER, FFESH

ZINC

STEAM

LIDUIO FUELS

FERROSILICNIV

FLIJORSPAK

PI TCHOIN-TAS

SODIUM OICHFOMATE

CAUSTIC SODA

3ODTUM CAFBONATE

CMLOR IPIE

STEEL \& IRON

ELECTPUIDES

FERHOUS SCPAP, FURCHASED

$\triangle M M O N I A$

OXYGEN, GASEOLIS

ALUMINUM FLIHIPIUE

CFYOLITE

COAL, RITUMINIDUS

PMDSPHIHF $99.999^{\circ}$

CADMIUY SULFIUE

INOIUM-TI: OXIDE

OPTHO-PMOSPHOROUS ACII)

-HOSPHORDUS TRICHLURIUE

(MISC. BIILX MATFRIALS)

\begin{tabular}{|c|c|c|}
\hline '4tllk & PEPCE IIT & PRחiJT \\
\hline MATEPIAL & SUPFLY & SRONTH \\
\hline WSAGE & $\Delta .5$ & RATE \\
\hline$M T$. & $B Y-P A \cap H$ & 1940 \\
\hline 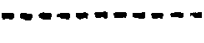 & $-\infty-\infty=-\infty$ & $-\infty-\infty$ \\
\hline & 50 & $10 . x$ \\
\hline 22911. & o. & $\frac{7}{7}$ \\
\hline$n$ & 0. & $a$ \\
\hline 139011. & $10 n$. & 1. \\
\hline 47405. & 0. & 3. \\
\hline 132.5. & $100 . *$ & 3. \\
\hline 2306250. & $n$ & 2. \\
\hline $1212 . E+6$ & 0. & 7. \\
\hline 0706. & 100. & $221 . *$ \\
\hline 342. & 0. & 3. \\
\hline 0 . & 1. & n. \\
\hline a. & 0 . & 3. \\
\hline 25. & 0. & 4. \\
\hline 10775. & 0. & 6. \\
\hline 1256 & 0. & 3. \\
\hline In5625. & 31. & 3. \\
\hline 301655. & 20. & 3. \\
\hline 39 & 1. & 3. \\
\hline 1. & 0 . & द. \\
\hline 111331. & 25. & 2 . \\
\hline 476040. & 1. & 3. \\
\hline 99988. & 0. & 3. \\
\hline 0. & 0 . & 3. \\
\hline 9. & 0. & 5. \\
\hline 804. & 0. & 3. \\
\hline 207. & 0. & 3. \\
\hline 1213. & 0. & 3. \\
\hline $301315 \mathrm{~h}$. & $n$. & $a$. \\
\hline 36540. & 0 . & 3. \\
\hline 358. & 1 . & 3. \\
\hline 231. & 0 . & 3. \\
\hline 8. 7. & 0. & 3. \\
\hline 6834. & 0 . & 3. \\
\hline 25. & n. & 4. \\
\hline at. & $-97 . ?$ & $-40 . ?$ \\
\hline 80. & $-99 . ?$ & -99.7 \\
\hline$n$. & 0. & 2. \\
\hline 27AH. & ?. & $16 \mathrm{e}$. \\
\hline 17256. & 0. & 9. \\
\hline 697 & 0. & $85 . *$ \\
\hline 27895. & $-00 . ?$ & $-90 . ?$ \\
\hline 36470 . & $-00 . ?$ & $-99, ?$ \\
\hline
\end{tabular}

PHESENT

SYSTEY TNE COSTS

1 YEAR NATION IN NFI

NOLL NONIJS SIKW IMPOAT

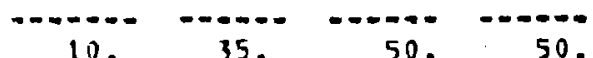

-.0.-

0.9.

3. $\quad 57 . *$

0.

31. 1.

$119 . * 24 .-4$

0.20 .00

$0.4 . \%$

0.

0.

1.

0.

85.*

0.

59.*

0.

39.

35.

79.

5.

1.

1.

0.

1.

1.

0 .

1.

0.

$-79 . ?$

$-99 . ?$

10,

$0, \quad 1$

0.

$-99 . ?$

$-99.7$

$-79 . ?$ 
TABLE 5. (continued)

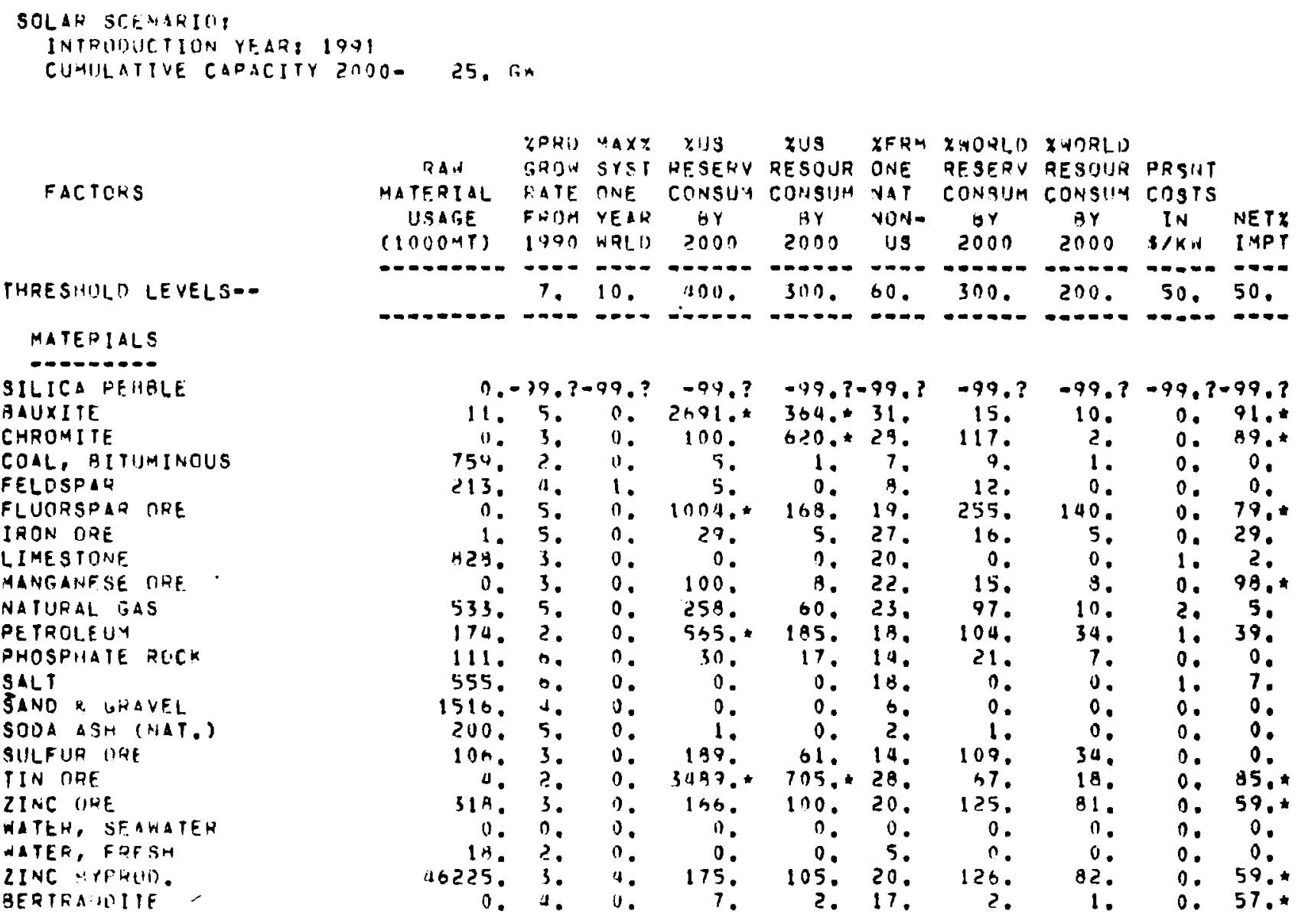


Sensitivity Case 2: Substitute tin oxide for indium-tin oxide Ind ium

Phosphine 99.999

Cadmium Sulfide

and the following "B" materials:

Baseline and Sensitivity

Beryllium

Cadmium

Petroleum coke

Ferromanganese

Tin

Zinc

Fluorspar
Bauxite

Chromite

Fluorspar ore

Manganese ore

Tin ore

Zinc ore

Zinc byproducts

Bertrandite

Petroleum

\section{"A" Material Discussions}

Indium and indium-tin oxide (ITO) may present both availability and cost constraints if the indium phosphide/cadmium sulfide solar. cell were deployed on a large scale basis (i.e., $25 \mathrm{GW}(\mathrm{p})$ by 2000). This cell would use 8796 MT of indium and 897 MT of ITO, requiring a $220 \%$ world production growth rate for indium and an 85\% world production growth rate for ITO between 1990 and 1991. The cost of the indium used in this cell would be about $\$ .12 /$ watt $(\$ 119 / \mathrm{KW})$.

By increasing the cell conversion efficiency from $10 \%$ to $15 \%$ (sensitivity Case 1) the quantity of indium required reduces to 5864 MT and ITO to 600 MT. In turn, the world production growth rates drop to $148 \%$ and $57 \%$ for indium and ITO respectively. The cost of the indium used in this cell is $\$ .08 /$ watt. Indium will still present availability and cost constraints to photovoltaics.

In the second sensitivity case (i.e., tin oxide substituted for indium-tin oxide with a 10\% conversion efficiency) eliminates the ITO problems; however, indium used in the active layer would still require a world production growth rate of $202 \%$ at a cost of $\$ .11 /$ watt. 
Figure 11 shows the relationship between indium costs, active layer thickness and deposition efficiencies. In order for indium costs to decrease to the threshold value of $\$ .05 /$ watt, the active layer thickness would have to be reduced from its present leve 1 of 3 microns to about 1.4 microns at a $35 \%$ process efficiency for planar reactive deposition. At a process efficiency of $50 \%$, the thickness of the active layer would only have to be reduced to about 2 microns. If all of the indium lost during planar reactive deposition, could be recycled, the present cost of indium would reach the \$.05/watt threshold level at an active layer thickness of 4.5 microns. The most optimistic case assumes a $15 \%$ cell conversion efficiency, a 100\% process efficiency and that tin oxide is substituted for indium-tin oxide in the window layer. In this case, the present cost of indium falls below the $\$ .05 /$ watt threshold level at about 6 microns.

A detailed discussion of indium availability is the subject of R. L. Watts et al. (1980). The following is a summary of indium supply problems relative to the requirements of the indium phosphide/cadmium sulfide backwall cell.

Indium is about as abundant as silver in the earth's crust. It is a byproduct of zinc refining, therefore the amount available depends upon zinc production. There are no deposits with sufficient concentration to process for indium alone. During zinc refining indium becomes concentrated in residues from retorts, and zinc anode slimes from which the indium is economically recoverable. Approximately $90 \%$ of the indium could be recovered from indiumrich residues; however, the overa 11 recovery from zinc ores is $40 \%$. Just how much of the available residues are being processed for indium recovery is unknown.

Three companies produce indium domestically. They are The Indium Corporation of America, its partner, New Jersey Alloy, and American Smelting and Refining Company. Canada is the main source of indium imports. Cominco, Ltd. is the only Canadian producer. A small percentage of foreign zinc plants produce indium. Production levels and stocks are largely unknown (company confidential).

The U.S. Bureau of Mines estimated 1973 world production at 54 MT, and refinery capacity at 128 MT. As was shown in Figure 12, world indium 


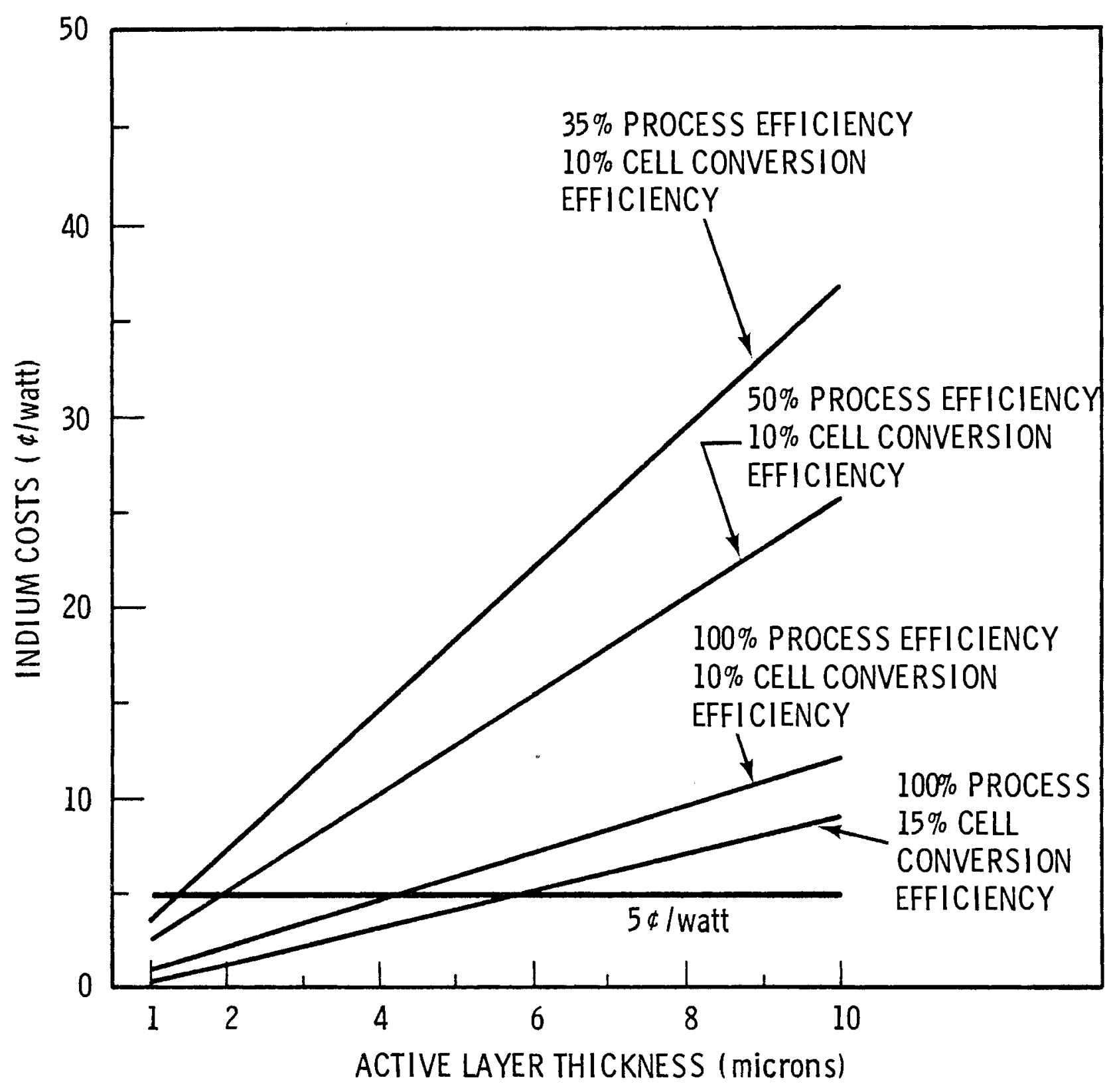

FIGURE 11. Indium Costs Versus Active Layer Thickness and Process Efficiency 


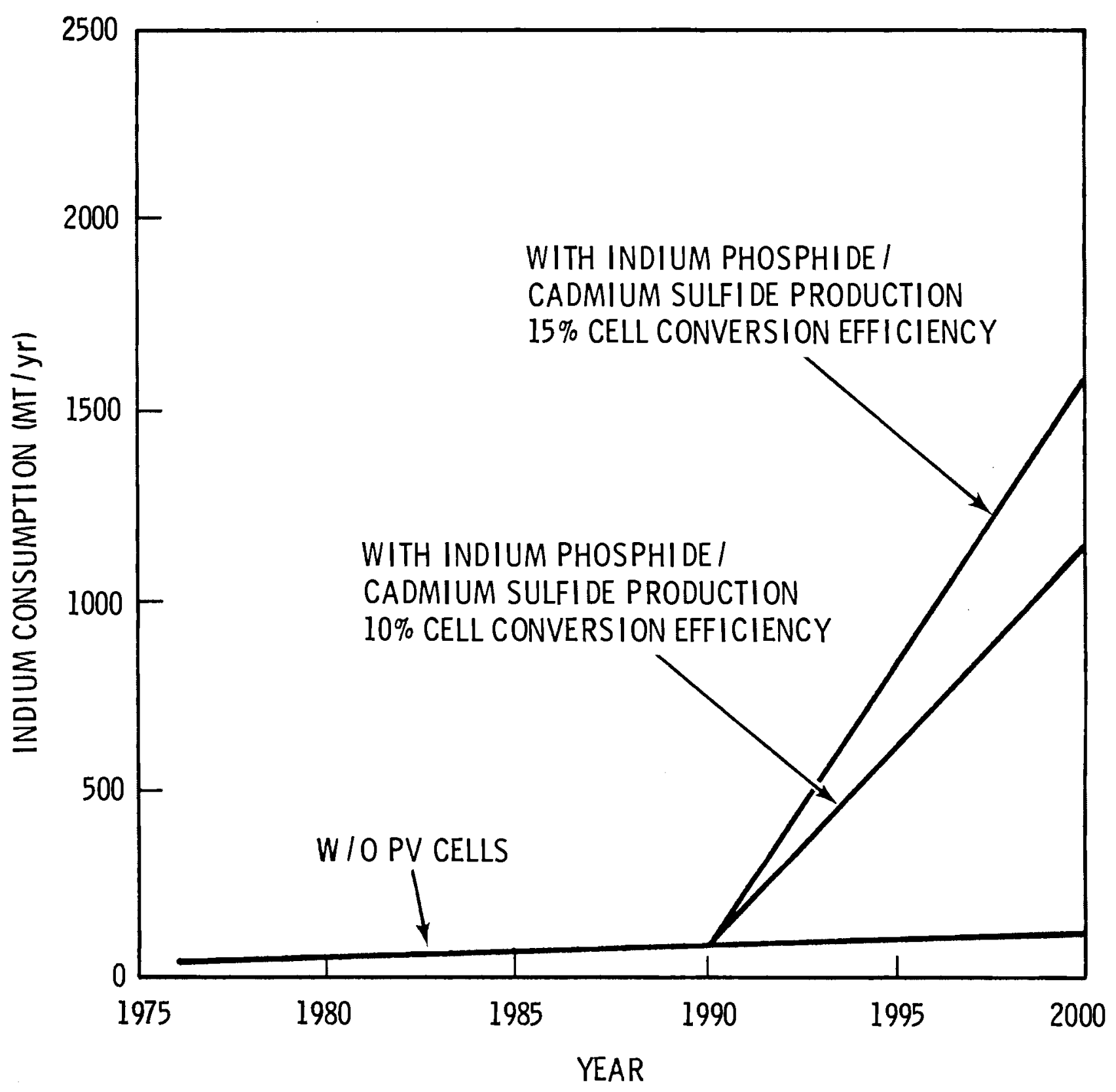

FIGURE 12. Project Market for Indium With and Without Indium Phosphide/Cadmium Sulfide Cell Production 
consumption, with the baseline indium phosphide/cadmium sulfide cells, is projected to be 1686 MT in the year 2000. U.S. (nonsolar) consumption is estimated to be 47 MT in 2000. It is unlikely that this level of indium production can be attained by 2000 . Domestic production in the year 2000 is estimated at 7 MT based on projected zinc capacity, current indium recovery processes, and estimated indium concentrations. This would indicate that the majority of U.S. indium will come from imports and stockpiles of metal and concentrates.

The indium content of zinc ores is highly variable. Most ores are not assayed for indium. Hence, the knowledge of world reserves and resources is poor. In the U.S. there is a shift towards zinc ores having lower indium contents. Estimates of U.S. indium reserves range from 300 to 1800 metric tons with additional resources of 300 to 5400 metric tons. Deployment of $25 \mathrm{GW}$ of indium phosphide/cadmium sulfide cells will require 8796 MT of indium.

The U.S. Bureau of Mines est imated (in 1975) that world reserves of indium were 1500 MT with almost 1900 MT of additional resources.

Since sufficient indium production will not be available to meet the increased demand by the indium phosphide/cadmium sulfide cell, based on the $25 \mathrm{GW}_{p}$ deployment scenario, it is recommended that the thickness of the active layer be reduced as much as possible, that the indium lost during deposition be recycled and that tin oxide be substituted for ITO in the window layer.

If these actions are not technically feasible, the supply of indium might be increased by several actions. Indium suppliers and indium phosphide/cadmium sulfide fabricators could enter into long term supply contracts.

The conditions of these contracts will vary, but they essentially state that the materials producer will supply a certain quantity of material per year and that the PV cell fabricators will purchase this material at a given price over a period of time.

The expansion of materials production capacity requires large quantities of capital and is expensive. With the high cost of borrowing money, material producers want to be sure of a viable future market for their additional output. Photovoltaic cell fabricators require a reliable flow of materials so 
that they can meet their production schedules. Long term contracts are a way of reducing risks to both the materials producer and PV cell fabricator.

Another benefit of long term contract is reduced transaction costs. When one material producer deals with the same PV cell fabricator over a period of time, the administrative costs of making the transaction decrease. People in one organization become familiar in doing business with another organization. These reduced transactions costs may be passed along to the PV cell fabricator in lower material prices (i.e., below normal quantity discounts).

The establishment of long term contracts between domestic PV cell fabricators and foreign material producers will not necessarily guarantee adequate material supplies in the future. This is particularly true of African and South American countries where the government frequently changes hands and the new governments do not have to honor previously established long term contracts.

Due to the large quantities of indium required by this cell, it would be wise to begin an indium stockpile program to help ensure future supplies.

Phosphine 99.999 is classified as an "A" material due to potential availability problems. The baseline characterization of the indium phosphide/ cadmium sulfide cell requires 2788 MT of phosphine between 1991 and 2000, and 502 MT in 2000. This usage of phosphine would require a world production growth rate of $162 \%$ between 1990 and 1991. In sensitivity case 1 (i.e., 15\% cel1 conversion efficiency) the usage of phosphine drops to 1859 MT between 1991 and 2000, and a corresponding world production growth rate of 115\%.

Phosphine is a highly toxic gas and is considered pyrophoric at $100^{\circ} \mathrm{F}$. It carries a DOT label as "poisonous gas and flammable gas". Its DOT class is "Poison A".

Its principal uses include doping, condensation catalysts, polymerization initiators, and production of phosphonium halides. In 1979, production of the electronic grade (99.999) was probably about 2.5 metric tons. An approximate price in quantity is about $\$ 187 / \mathrm{Kg}$.

Current suppliers include:

Synthatron Corporation 
Matheson Gas

Airco.

Two other producers, Great Western Inorganic and Phoenix Materials recently discontinued production. The U.S. is an exporter of phosphine.

Process routes to phosphine were not revealed by suppliers. There are various routes that are judged about equal. One efficient route would involve heating of ortho phosphorous acid $\left(\mathrm{H}_{3} \mathrm{PO}_{3}\right)$ and condensing the evolved phosphine. Another route involves hydrolys is of phosphorous trichloride with concentrated hydrochloric acid. Regardless of the route, no basic material supply problems should be anticipated.

Phosphine production can certainly be expanded as long as it is profitable to the manufacturer. Therefore, we recommend that long term contracts (see indium discussion) be established between phosphine manufacturers and cell fabricators to ensure a viable future market for phosphine. Also, new phosphine production facilities should be located near the indium phosphide/cadmium sulfide cell facility to minimize transportation hazards.

Cadmium Sulfide is classified as an "A" material since its usage in the baseline indium phosphide/cadmium sulfide cell would require $27 \%$ of the world's cadmium sulfide production (a11 grades) in one year. In sensitivity Case 1 ( $15 \%$ cell conversion efficiency) this reduces to $20 \%$.

Figure 13 shows the relationship between the possible range cadmium sulfide layer thicknesses and the maximum percent of world production consumed by the indium phosphide/cadmium sulfide cell in one year. Four different cases are presented: the baseline case, the sensitivity case and two cases showing the results of recycling of the cadmium sulfide lost in the evaporation process. The $10 \%$ reference line indicates the threshold level used in the CMAP program.

If the thickness of the cadmium sulfide active layer could be reduced to less than 2 microns (in the $10 \%$ cell efficiency case), photovoltaics consumption of this material should not have a severe impact on the world cadmium sulfide market. Likewise, if the cell efficiency could be improved to $15 \%$ and if all of the cadmium sulfide lost during evaporation were recycled, the layer 


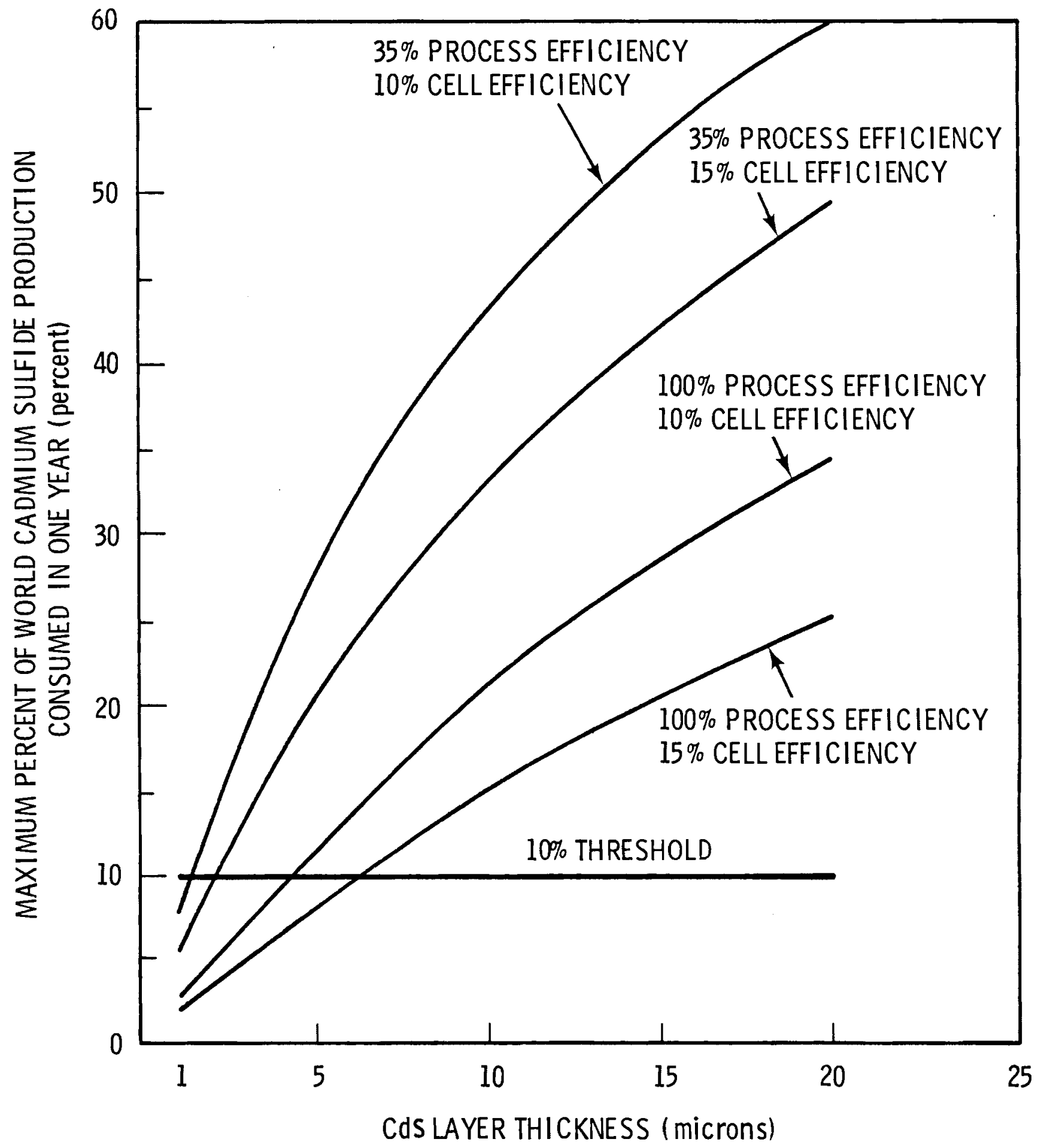

FIGURE 13. Cadmium Sulfide Layer Thickness and Process Efficiency versus Maximum Percent of World Cadmium Sulfide Production Consumed in One Year 
thickness could remain at 5 microns and still not impact the world market. However, if the indium phosphide/cadmium sulfide were to use more than $10 \%$ of the world production in one year, the price of cadmium sulfide may increase substantially and hinder achieving the desired cost goals.

Therefore it is recommended that the work be directed towards increasing the overall indium phosphide/cadmium sulfide cell efficiency and recycling of the lost cadmium sulfide. Efforts should be made to develop commercial cadmium sulfide production capacity. Also, onsite production of cadmium sulfide should be considered to ensure the desired level of purity.

\section{"B" Material Discussions}

The following "B" materials were reviewed and found not to constrain the deployment of the indium phosphide/cadmium sulfide cell. Generally, these materials are used in relatively small quantities and the cost to solar is low. Therefore, only severe future supply disruptions would significantly impact the indium phosphide/cadmium sulfide solar cells. The future availability and costs of these "B" materials should not present major obstacles in the large scale deployment of the indium phosphide/cadmium sulfide cells. However, these "B" materials should be subjected to periodic review.

Beryllium/Bertrandite are used in the indium phosphide/cadmium sulfide cell in the p-dopant. They are classified as "B" materials since approximately $60 \%$ of these materials are imported from Brazil. However, future availability problems are not anticipated.

Petroleum coke, and cadmium are both byproducts and thus, their production is dependent upon petroleum and zinc respectively.

Ferromanganese, manganese ore, fluorspar, flouorspar ore, tin, tin ore, chromite, bauxite, zinc byproducts are all classified as "B" materials since 60 to $98 \%$ of these materials are imported into the U.S. (see Table 6), and U.S. reserves of the ores are small. However, none of these materials is expected to present future availability or cost problems to photovoltaics. 
TABLE 6. "B" Material Net Import Reliance and Major Foreign Sources

\begin{tabular}{|c|c|c|}
\hline "B" Material & $\begin{array}{c}\text { Net } \\
\text { Import }\end{array}$ & $\begin{array}{l}\text { Foreign } \\
\text { Source }\end{array}$ \\
\hline Ferromanganese & $98 \%$ & France \\
\hline Manganese ore & $98 \%$ & Gabon \\
\hline Fluorspar/Fluorspar ore & $79 \%$ & Mexico \\
\hline Zinc/zinc ore & $59 \%$ & Canada \\
\hline Tin/Tin ore & $85 \%$ & Malaysia \\
\hline Chromite & $89 \%$ & Rep. of South Africa \\
\hline Bauxite & $91 \%$ & Jama ica \\
\hline
\end{tabular}

\section{ZINC PHOSPHIDE MIS SOLAR CELL}

\section{Cell Description}

A generalized structure for $2 n_{3} P_{2}$ cells is shown schematically in Figure 14. The processes used in depositing many of the layers are not yet well established. Deposition processes discussed are based on current information.

The $\mathrm{p}-\mathrm{Zn} \mathrm{n}_{3} \mathrm{P}_{2}$ active layer ranges in thickness from 1 to $10 \mu \mathrm{m}$ and is deposited using polycrystalline $2 \mathrm{n}_{3} \mathrm{P}_{2}$ in the close spaced vapor deposition process. Both MIS and heterojunction cell structures are being studied. The top transparent metal layer of the MIS structure is $\sim 100 \AA$ of evaporated $\mathrm{Mg}$. Alternate metals used to form the barrier are $A 1$ and $B e$, usually evaporated from $A 1$ and Be sources. Diffusion of $M g$ into $Z_{3} P_{2}$ forms an $n^{+} Z n_{3} P_{2}$ layer $\sim 500 \AA$ thick. This layer reduces contact resistance between the active layer and $\mathrm{Mg}$ layer. A carbon layer of 0.1-5 $\mu \mathrm{m}$ thick prevents diffusion of the metal support substrate into the active layer. The carbon is deposited from acetylene $\left(\mathrm{C}_{2} \mathrm{H}_{2}\right)$ by a plasma polymerization process.

The heterojunction cell design uses $1-10 \mu \mathrm{m}$ of $\mathrm{ZnO}$ in place of $\mathrm{Mg}$. The $\mathrm{ZnO}$ is presently being sputtered using a $\mathrm{ZnO}$ target and $\mathrm{H}_{2}+\mathrm{Ar}$ as sputtering gases. $H$ acts as an $n$-dopant for the $Z n 0$. Substrates are low cost metals such 


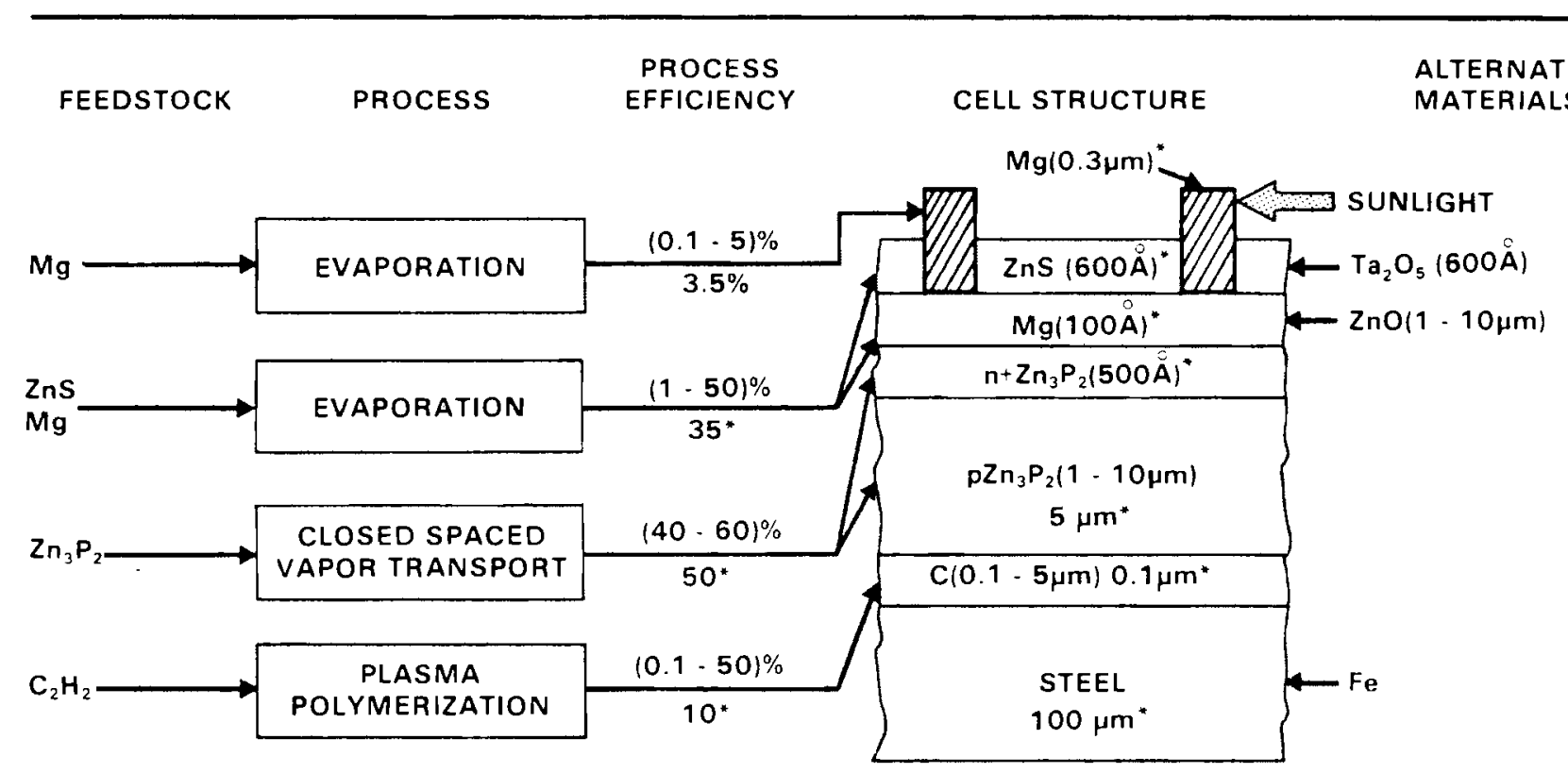

* most likely VAlue

BASELINE CELL EFFICIENCY $10 \%$

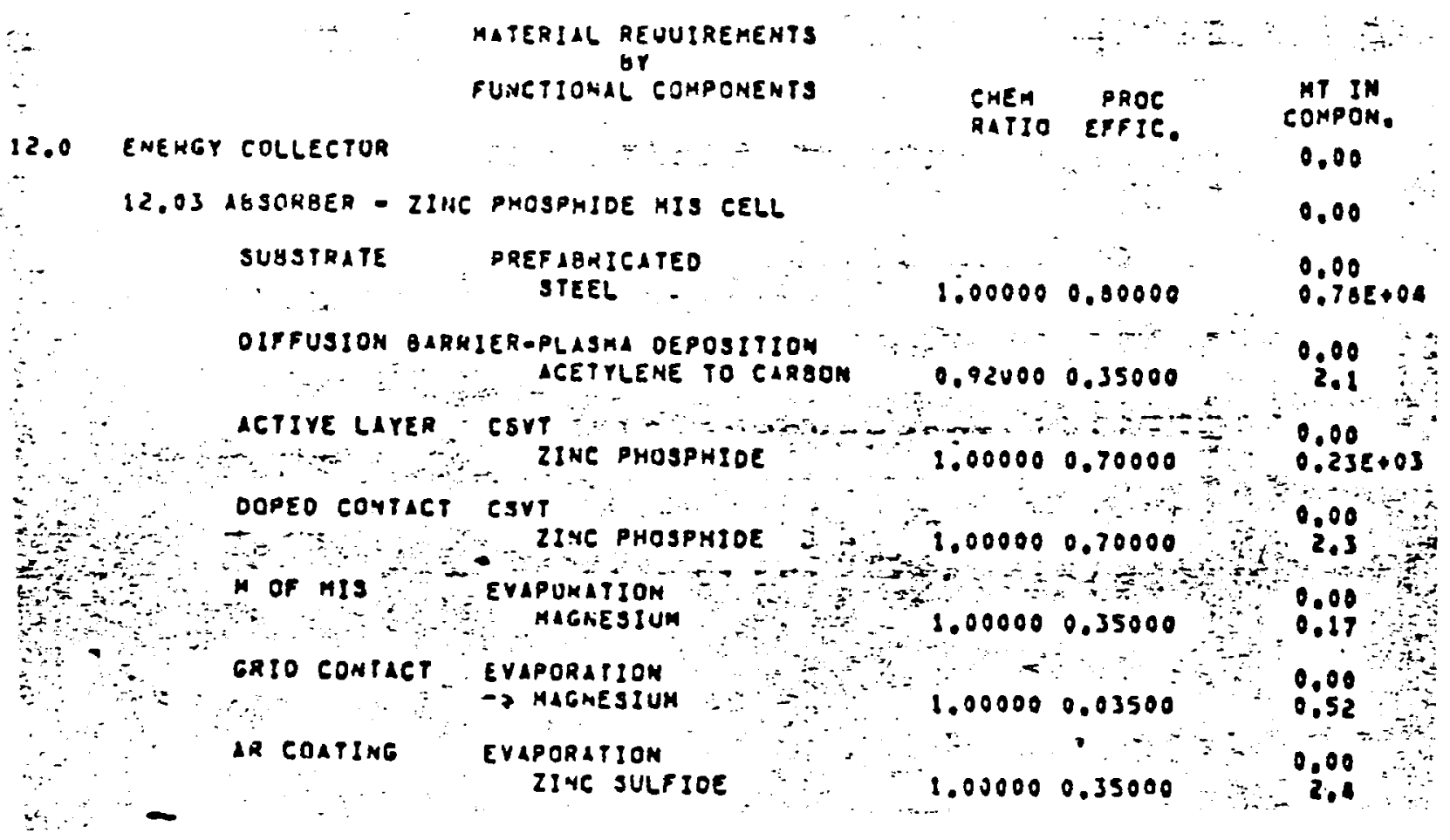

FIGURE 14. The Baseline Zinc Phosphide MIS Solar Ce11 
as steel or Fe. Both MIS and heterojunction cell structures use a grid contact of $0.3 \mathrm{\mu m}$ thick evaporated or sputtered $\mathrm{Mg}$.

A single layer $\mathrm{ZnS}(\mathrm{n}=2.3)$ quarter wavelength antireflective coating tuned near $600 \mathrm{~nm}$ is used. The $\mathrm{ZnS}$ is usually sputtered or evaporated using a ZnS target or source. $\operatorname{Ta}_{2} \mathrm{O}_{5}(n=2.3)$ is sometimes used as an antireflective coating and is usually e-beam evaporated from a $\mathrm{Ta}_{2} \mathrm{O}_{5}$ source.

In Figure 14, the MIS cell is used to illustrate materials requirements of $\mathrm{Zn}_{3} \mathrm{P}_{2}$ solar cells, including alternate materials. Representative deposition processes and associated feedstock materials are shown in conjunction with the range of efficiencies considered typical for each process.

$\mathrm{Zn}_{3} \mathrm{P}_{2}$ solar cells having highest efficiencies employ layer thicknesses designated at "most likely". A 10\% cell conversion efficiency was assumed for the baseline cell. The close spaced vapor transport deposition process and the plasma polymerization process are discussed in a later section. All other processes have been discussed elsewhere (R. L. Watts et al., 1979).

\section{Screening Results}

Review of the CMAP screening of the baseline (see Table 7) and sensitivity zinc phosphide solar cell identified the following "A" materials:

Baseline

zinc phosphide

Sensitivity Case: $15 \%$ ce 11 conversion efficiency

zinc phosphide

and the following "B" materials:

Baseline and Sensitivity

Petroleum coke

Bauxite

Ferromanganese

Fiuorspar ore

Zinc

Manganese ore

Fluorspar

Zinc ore

Petroleum 
TABLE 7. Bulk Material Requirements for: Zinc Phosphate MIS Solar Cell Baseline

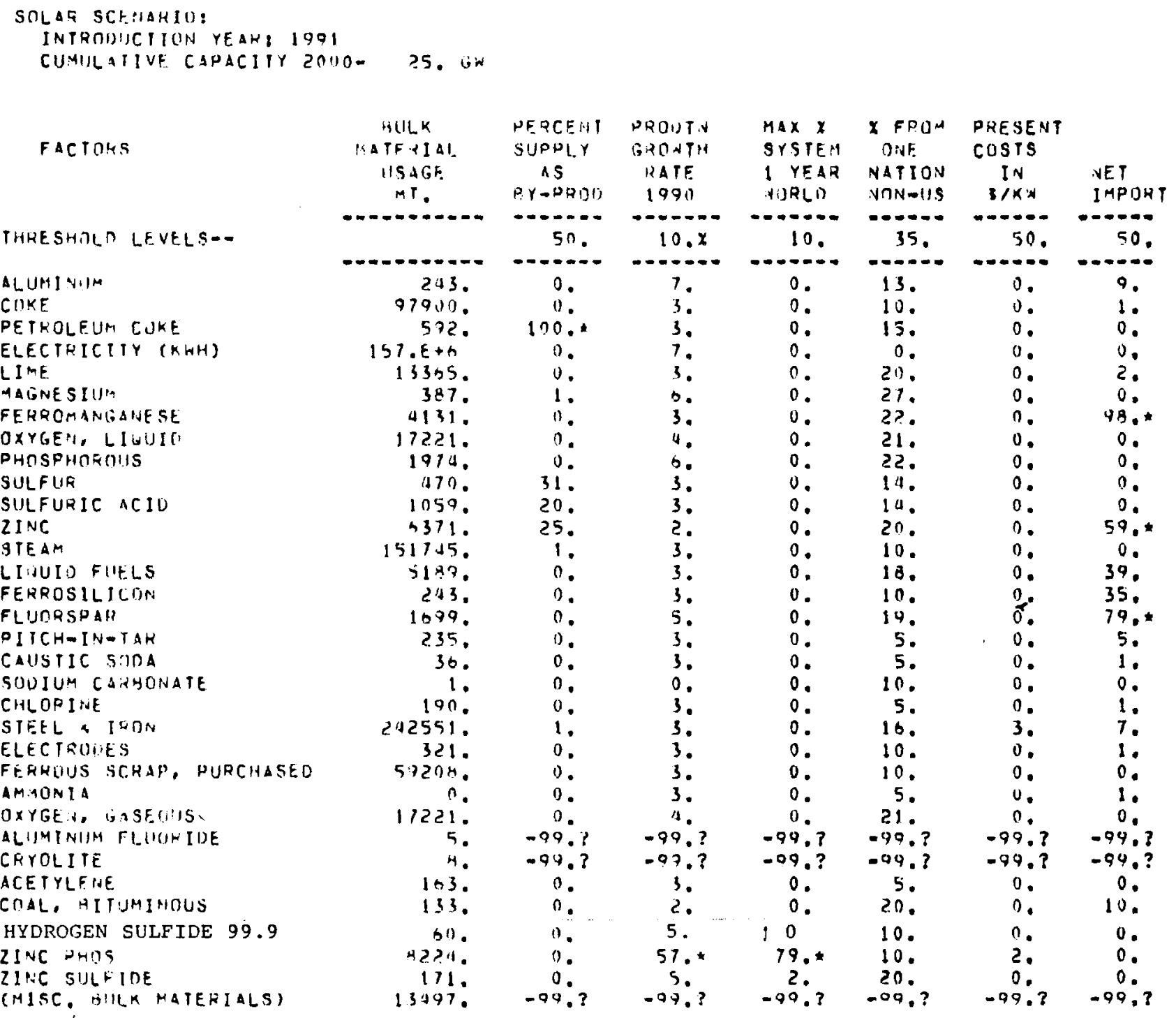


TABLE 7. (continued)

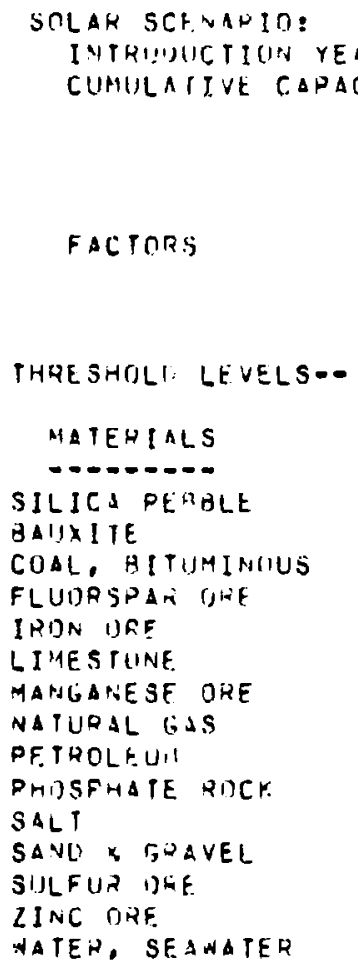




\section{"A" Material Discussions}

Zinc Phosphide is used in the active and doped contact layers of the zinc phosphide solar cell. In the baseline case, 8224 MT of zinc phosphide would be consumed by this cell between 1991 and 2000. This level of consumption would require a world zinc phosphide production growth rate of $57 \%$ (between 1990 and 1991) and would consume 79\% of the world's zinc phosphide production in one year. (Measured as solar's consumption of zinc phosphide in $2000 /$ solar and nonsolar consumption of zinc phosphide in 2000.)

In the sensitivity case the cell conversion efficiency was increased to 15\%. Zinc phosphide requirements decreased to 5483 MT between 1991 and 2000, or a $39 \%$ world production growth rate. This ce 11 would consume $71 \%$ of the world's zinc phosphide production in one year.

Figure 15 shows the relationship between the thickness of the zinc phosphide active and doped contact layers and the maximum percent of world production this cell would consume in one year. The range of thicknesses used for the active layer is from 1 to 10 microns. The thickness of the doped contact layer is held constant at 500A. Two efficiencies are assumed for the closedspace vapor transport (CSVT) process: 70\%, the most likely CSVT process efficiency and $100 \%$, which assumes that the lost zinc phosphide could be recycled. The 10\% reference line indicates the threshold level for this screening criteria. At both process efficiencies and at all possible layer thicknesses, solar's consumption of zinc phosphide exceeds the 10\% threshold level. Even at 1 micron and 100\% process efficiency, this ce 11 would require $35 \%$ of the world's zinc phosphide production in one year. If solar were to represent such a substantial portion of the world market for zinc phosphide, the price of this material would likely increase from $\$ 7400 / M T$.

Currently, only one U.S. firm produces zinc phosphide and wishes to avoid disclosing company confidential data. Therefore, information on zinc phosphide is limited. We estimate that 100 MT of zinc phosphide is being produced in the U.S. annually. It is highly toxic and is used as a rodenticide.

The small quantities of zinc phosphide used in the technical research on the zinc phosphide cell are made on site by heating elemental zinc with 


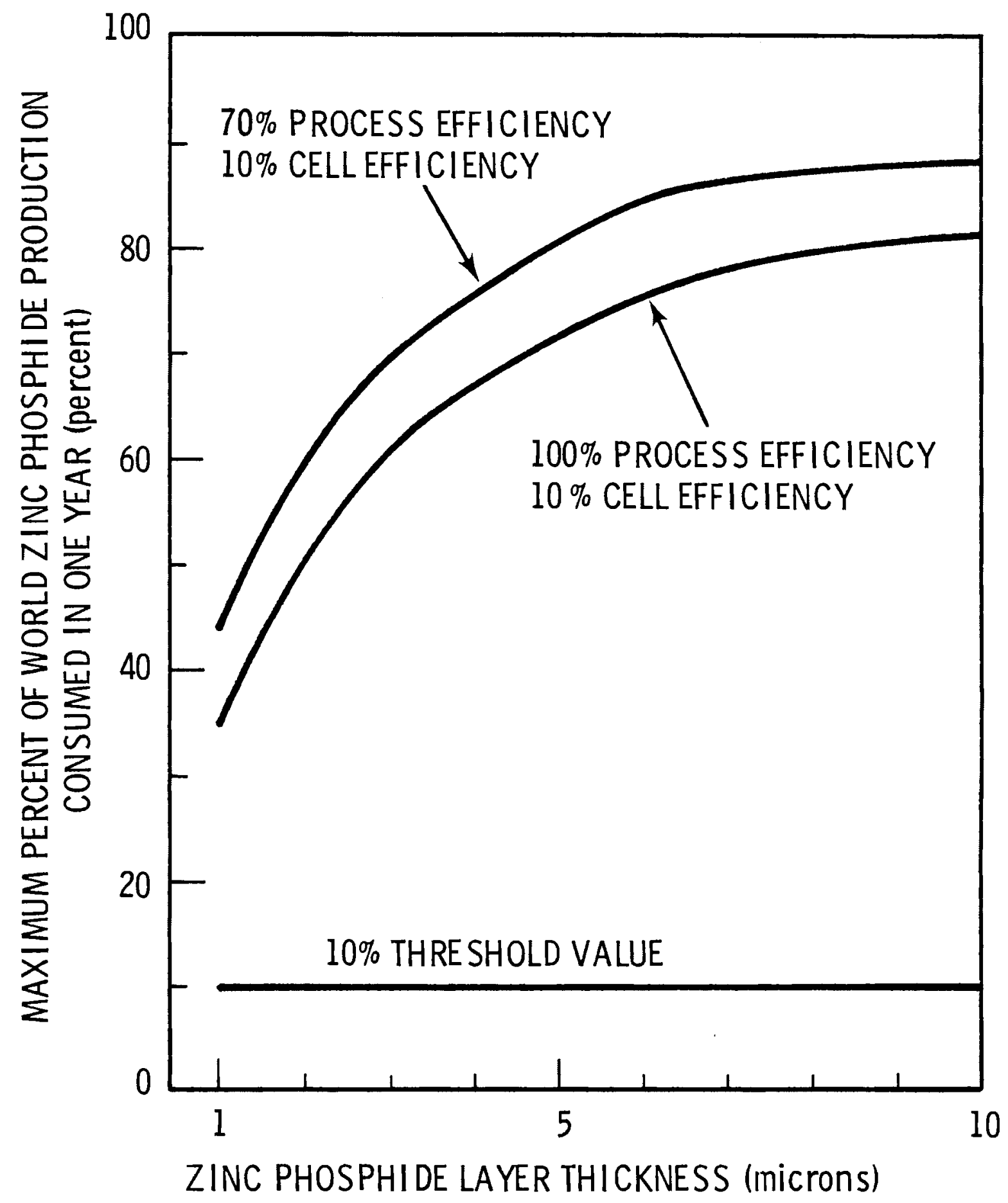

FIGURE 15. Thickness of the Zinc Phosphide Active and Doped Contact Layers Versus Maximum Percent of World Production Consumed in One Year 
elemental phosphorous. This process would be fairly easy to scale-up. We recommend that a zinc phosphide production facility be established at the cell fabrication site. This would ensure adequate supplies of zinc phosphide at the desired purity levels if $25 \mathrm{GW}_{\mathrm{p}}$ of this cell were deployed by 2000.

"B" Material Discussions

The following "B" materials were reviewed and found not to constrain the deployment of the zinc phosphide solar cell. Generally, these materials are used in relatively small quantities and the costs to solar is low. Therefore, only severe future supply disruptions would significantly impact the zinc phosphide solar cells. The future availability and costs of these "B" materials should not present major obstacles in the large scale deployment of the zinc phosphide cell; however, these materials should be subject to periodic review.

Ferromanganese, manganese ore, tin, tin ore, zinc, zinc ore, fluorspar and fluorspar ore are all classified as "B" materials because of the U.S. dependence on foreign sources (ranging from $59 \%$ to $98 \%$, see Table 8 ). However, severe future supply disruptions are not anticipated for any of these materials and therefore should not present major availability or cost problems in the future.

TABLE 8. "B" Material Net Import Reliance and Major Foreign Sources

\begin{tabular}{lcll}
\multicolumn{1}{c}{} & $\begin{array}{c}\text { Net } \\
\text { Import }\end{array}$ & $\begin{array}{l}\text { Foreign } \\
\text { Source }\end{array}$ \\
\cline { 1 - 1 } & & $98 \%$ & France \\
Manganese ore & $98 \%$ & Gabon \\
Fluorspar/Fluorspar ore & $79 \%$ & Mexico \\
Zinc/zinc ore & $59 \%$ & Canada \\
Tin/Tin ore & $85 \%$ & Canada
\end{tabular}


CADMIUM TELLURIDE SOLAR CELL

\section{Cell Description}

The backwall CdTe solar cell currently under investigation is shown schematically in Figure 16. The CdTe is usually evaporated from CdTe bulk material or electro-deposited using $\mathrm{Te}$ and $\mathrm{CdSO}_{4}$ with layer thicknesses ranging from 1$10 \mu \mathrm{m}$. The CdS layer may eventually be eliminated from the cell structure; therefore, 0 has been included as a layer thickness. CdS is currently being evaporated from bulk CdS in layers up to $20 \mu \mathrm{m}$ in thickness. The 0.1-0.4 $\mu \mathrm{m}$ thick ITO window layer is either e-beam evaporated using ITO as a source, sputtered using an ITO target or chemically sprayed using solutions of $\mathrm{InCl}_{2}$ and $\mathrm{SnCl}_{4}$. Soda lime glass (0.125 inches) is used as a support substrate. The back contact is a $0.5 \mu \mathrm{m}$ thick layer of $5 \% \mathrm{Cu}$ in $\mathrm{C}$. This layer is usually painted using aquadag with $\mathrm{C}$ and $\mathrm{Cu}$ in suspension but may also be evaporated using a $5 \% \mathrm{Cu}$ in $\mathrm{C}$ source. No dopants are used in this ce 11 ; however, the $\mathrm{CdS}$ layer is doped stoichiometrically by making it Cd-rich.

Other materials have been successfully used in place of the ITO window layer and the $5 \% \mathrm{Cu}$ in $\mathrm{C}$ back contact. $\mathrm{SnO}_{2} 0.2 \mu \mathrm{m}$ thick with an $\mathrm{Al}$ grid can serve as a window layer-electrical grid contact combination. The Al grid is first evaporated on the glass substrate using an $\mathrm{Al}$ source. $\mathrm{SnO}_{2}$ is then either sprayed using solutions containing $\mathrm{SnCl}_{4}$, sputtered using an $\mathrm{SnO}_{2}$ target or evaporated from an $\mathrm{SnO}_{2}$ source. Metallization can replace the $5 \% \mathrm{Cu}$ in $\mathrm{C}$ back contact. Typical contact metals are evaporated $\mathrm{Ni}$, Bi or Sb.

All alternate cell design which is still in the developmental stage is a front wall cell employing 5-10 $\mu \mathrm{m}$ of CdTe deposited over a $\mathrm{Bi}$ or Pb-coated graphite support substrate ( 0.125 inches). The CdTe is deposited by a vapor transport process using $\mathrm{Cd}$ and $\mathrm{Te}$ in an $\mathrm{H}_{2}$ carrier gas. The metals are evaporated in $1 \mu \mathrm{m}$ thick layers using either a $\mathrm{Bi}$ or $\mathrm{Pb}$ source. The top layer of the heterojunction is 1-2 $\mu \mathrm{m}$ of $\mathrm{CdS}$, evaporated from bulk CdS. An Ag contact grid $(2 \mu \mathrm{m})$ is presently evaporated on to the CdS layer. Al is expected to replace this layer. The $A l$ is also evaporated. The completed cell has a quarter wavelength oxide antireflection coating tuned near $600 \mathrm{~nm} . \mathrm{TiO}_{2}(\mathrm{n}=2.5)$ and $\mathrm{Ta}_{2} \mathrm{O}_{5}(n=2.3)$ with thicknesses of $2600 \AA$ and $650 \AA$, respectively, are 


\section{CdTe SOLAR CELLS}
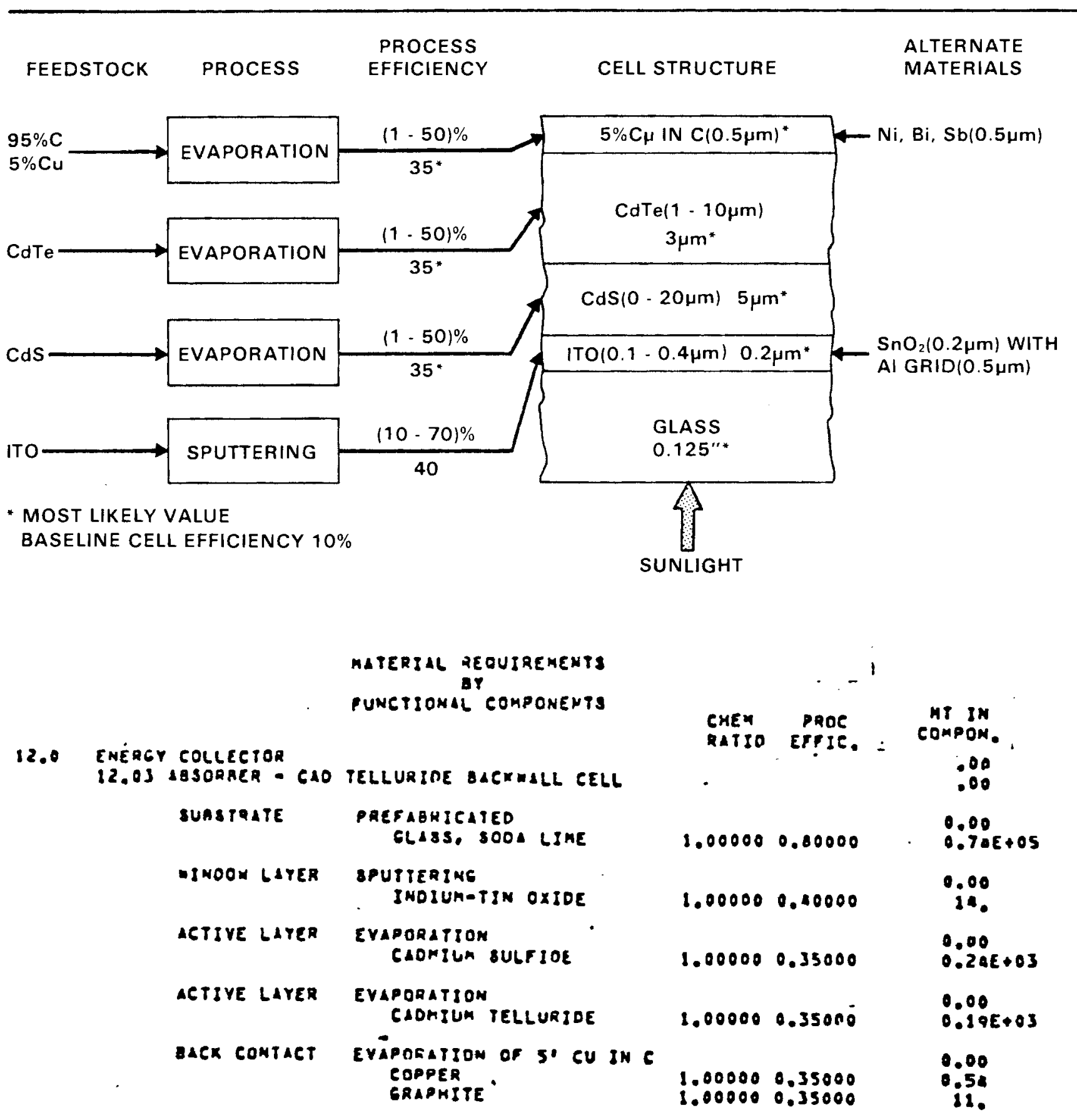

FIGURE 16. The Baseline Cadmium Telluride Backwall Solar Cell 
used in this cell design. Oxide coatings are usually sputtered on or evaporated using a bulk oxide target or source.

In Figure 16, the CdTe back wall cell is used to illustrate materials requirements for CdTe solar cells, including alternate materials. Representative deposition processes and their associated feedstock materials are shown in conjunction with the range of process efficiencies considered typical for each process. Cel1 conversion efficiency are predicted to range from 10 to $1.5 \%$. A cel1 conversion efficiency of $10 \%$ was assumed for the baseline cell. Layer thicknesses designated as "most likely" are representative of state-of-the-art CdTe solar cells. The painting deposition process is discussed along with the screen printing process in a later section. All other processes have been discussed elsewhere (R. L. Watts et al., 1979).

Screening Results

Review of the CMAP screening of the baseline (Table 9) and sensitivity. Cadmium telluride solar cell identified the following "A" materials:

\section{Baseline}

Indium

Indiun-tin oxide

Tel lurium

Cadmium telluride

Cadmium sulfide

Sensitivity Case 1: $15 \%$ ce 11 conversion efficiency

Ind ium

Indium-tin oxide

Tellurium

Cadmium telluride

Cadmium sulfide

Sensitivity Case 2: substitute tin oxide for indium tin oxide

Tellurium

Cadmium telluride

and the following "B" materials: 
TABLE 9. Bulk Material Requirements for: Cadmium Telluride Backwall Solar Cell Baseline

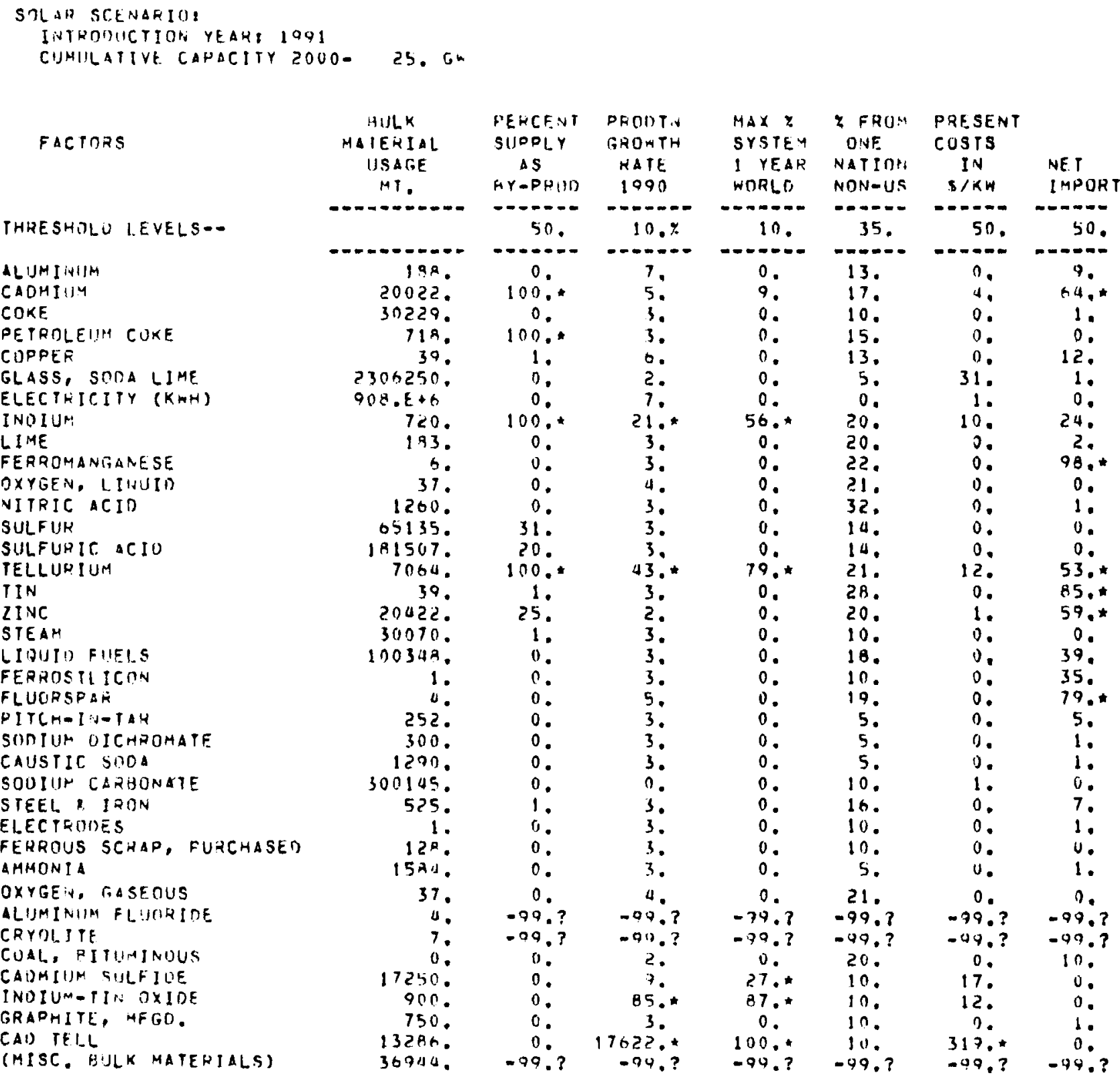


TABLE 9. (continued)

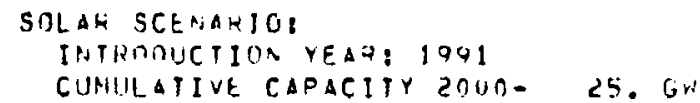

FACTIOUS

THRESHDLI: LEVELS--

MATELIALS

SILICA PEHBLE

BAUXITE

CHROAITE

CUAL, RITUMINOUS

COPPER GHE

FEL ISPAK

FLUORSPAR ORE

IHON ORF

LIMESTUNE

MANGANESE GHE

NATURAL TAS

PETFOLEIJM

SALT

SANO \& GAAVFL

SODA ASH (NAT,)

SULFUK OHE.

TIN ORF

IINC ORE

ZINC FYHKIJD.

COPPEF AYFRIID. 2

25. Gr

\begin{tabular}{|c|c|c|c|c|c|c|c|c|c|}
\hline & IPAD & $\operatorname{MAx}$ & $x \cup s$ & 2113 & XFH:- & XWOPLD & $X W O K L D$ & & \\
\hline fram & GROW & SYst & PFSERV & NESUUR & ONE & RESEDV & RESSIUA & PRSWT & \\
\hline$A T F A I \wedge L$ & N.TE & QNF. & CONSIA & CONSUH & HAT & CUN51JH & CoNSUM & Costs & \\
\hline USAliE & F & $Y \in \triangle Q$ & AY & QQY & NODAl- & $\mu y$ & or & IN & NE T Y \\
\hline $1000 \mathrm{MT}$ & 1090 & WELD & 2000 & 2000 & US & 2000 & 2000 & $s / K$ w & INPT \\
\hline - & $=$ & $=--0$ & $-\infty$ & $7-\infty-0$ & - & $-0-0.0$ & $=-$ & - & \\
\hline & $=--$ & $\begin{array}{l}10 . \\
--2\end{array}$ & 100 & 300 & $\begin{array}{l}60 . \\
=-0\end{array}$ & 0. & 00 & 5 & \\
\hline
\end{tabular}

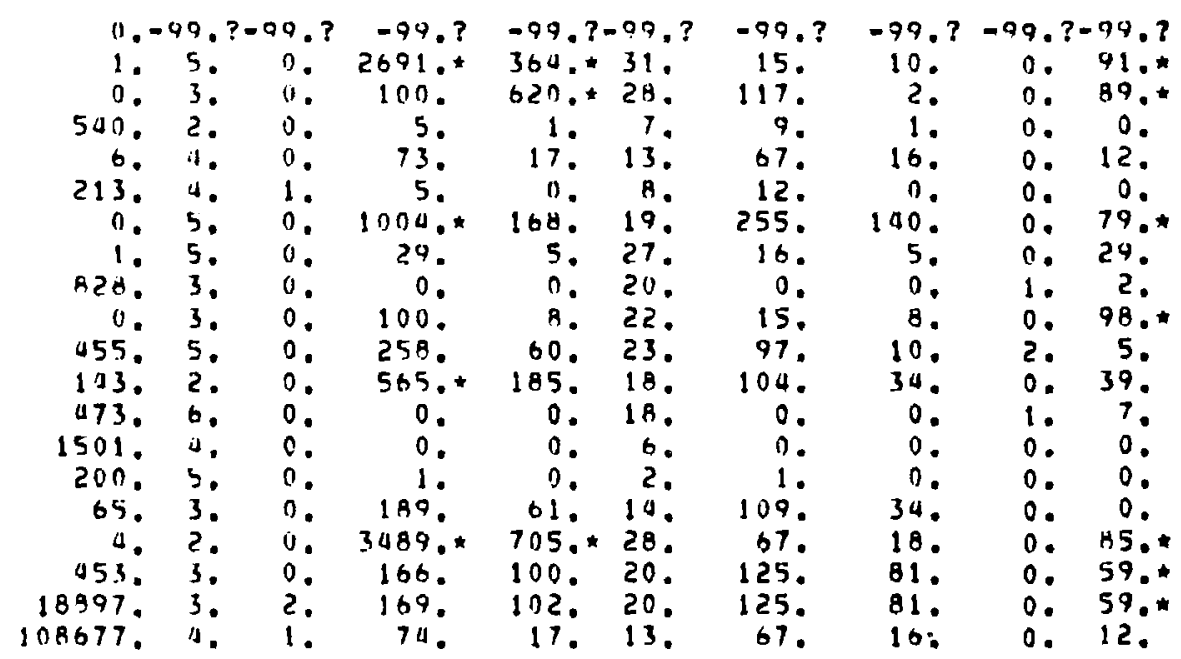




\section{Baseline and Sensitivity Cases}

$\begin{array}{ll}\text { Cadmium } & \text { Bauxite } \\ \text { Petroleum coke } & \text { Petroleum } \\ \text { Ferromanganese } & \text { Manganese ore } \\ \text { Tin } & \text { Tin ore } \\ \text { Zinc } & \text { Zinc ore } \\ \text { Fluorspar } & \text { Fluorspar ore } \\ & \text { Zinc (byproduct) }\end{array}$

Chromite

\section{"A" Materials Discussions}

Tellurium and cadmium telluride demand would be dominated by CdTe photovoltaic requirements for $25 \mathrm{GWp}$ of this ce 11 . Some $100 \%$ of the CdTe demand and $79 \%$ of the Te demand would be consumed by PV cell production in the year 2000 . Maximum required production growth rates are $17,600 \%$ and $43 \%$ respectively.

At current prices, the CdTe feedstock material of $5 \mathrm{~N}(99.999 \%)$ purity costs about $\$ .60 /$ gram or $\$ .32 /$ watt of baseline cell. Thus the raw CdTe cost is equal to the total DOE module cost goal of $\$ .15$ to $\$ .40 /$ watt. Although the current prices for elemental cadmium and tellurium of $5 \mathrm{~N}$ purity suggest the potential for substantially lower CdTe costs, a surge in photovoltaic demand beyond existing stocks and production capacity could cause rapid price increases for the elements. Currently, about half the U.S. tellurium consumption is imported.

The current small production of CdTe is used largely in infrared detectors. CdTe is produced by reacting the purified elements in quartz containers at elevated temperature. The price of $5 \mathrm{~N}$ CdTe in MT quantities from various sources was quoted from $\$ 350,000$ to $\$ 800,000$ per MT. At $\$ 600,000 / M T$ the material cost for the CdTe layer in the baseline case is $\$ .32 /$ watt. At that price for CdTe the layer thickness would have to be reduced from 3 microns to less than 0.5 microns to keep the CdTe cost below the $\$ .05 /$ watt threshold cost used in the computerized screening. Current prices for elemental cadmium and tellurium indicate some potential for cost reduction through economy of scale 
of CdTe production, use of elemental Cd \& Te rather than the compound CdTe, or by use of $4 \mathrm{~N}$ purity rather than $5 \mathrm{~N}$ purity.

Figure 17 illustrates those potential cost reductions. The elemental cadmium and tellurium costs are based upon the following current prices per MT:

\begin{tabular}{|c|c|c|c|}
\hline & $5 \mathrm{~N}$ & $4 \mathrm{~N}$ & $99.5 \%$ \\
\hline mium & $\$ 55,000$ & $\$ 22,000$ & $\$ 5,500$ \\
\hline liurium & $\$ 154,000$ & $\$ 68,000$ & $\$ 40,000$ \\
\hline
\end{tabular}

The $99.5 \%$ pure commercial commodities are not sufficiently pure for photovoltaic use, but are included above to indicate purification costs. Figure 17 shows that layer costs are kept below \$.05/watt using elemental Cd+Te if the layer thickness is kept below 2.5 microns for $5 \mathrm{~N}$ purity or below 5 microns for $4 \mathrm{~N}$ purity. Of course improved cell efficiency and process efficiency would be beneficial.

The impact of CdTe cell requirements on world tellurium consumption is illustrated in Figures 18 and 19. Tellurium is principally a byproduct of the electrolytic refining of copper. Tellurium is concentrated in the anode slimes. Outside of the U.S., some tellurium is recovered in the refining of lead and zinc, and in one case gold. Anode slimes are processed primarily for gold and silver and occasionally for platinum group metals, while tellurium as well as selenium are available to refiners at the added cost of recovery and refining. A ton of blister copper refinery feed contains an average of $0.2 \mathrm{~kg}$ of tellurium, $0.065 \mathrm{~kg}$ being recovered on the average during the 1964 to 1973 period (U.S. Bureau of Mines 1975). Using this recovery rate, the Bureau of Mines estimated U.S. production of tellurium at 220 MT in the year 2000 . If the same ratio were applied to the world primary copper demand (U.S. Bureau of Mines 1975), 1310 MT of tellurium could be produced worldwide in the year 2000, if all anode slimes were processed for tellurium recovery. Some 1270 MT of tellurium would be required for the baseline CdTe cells that year. The U.S. Bureau of Mines (1975) projected total world demand for tellurium (only a small fraction going to PV cel1s) to be about 350 MT in the year 2000. The combined world demand for tellurium in the year 2000 is 1620 MT (as shown in Figure 18), 


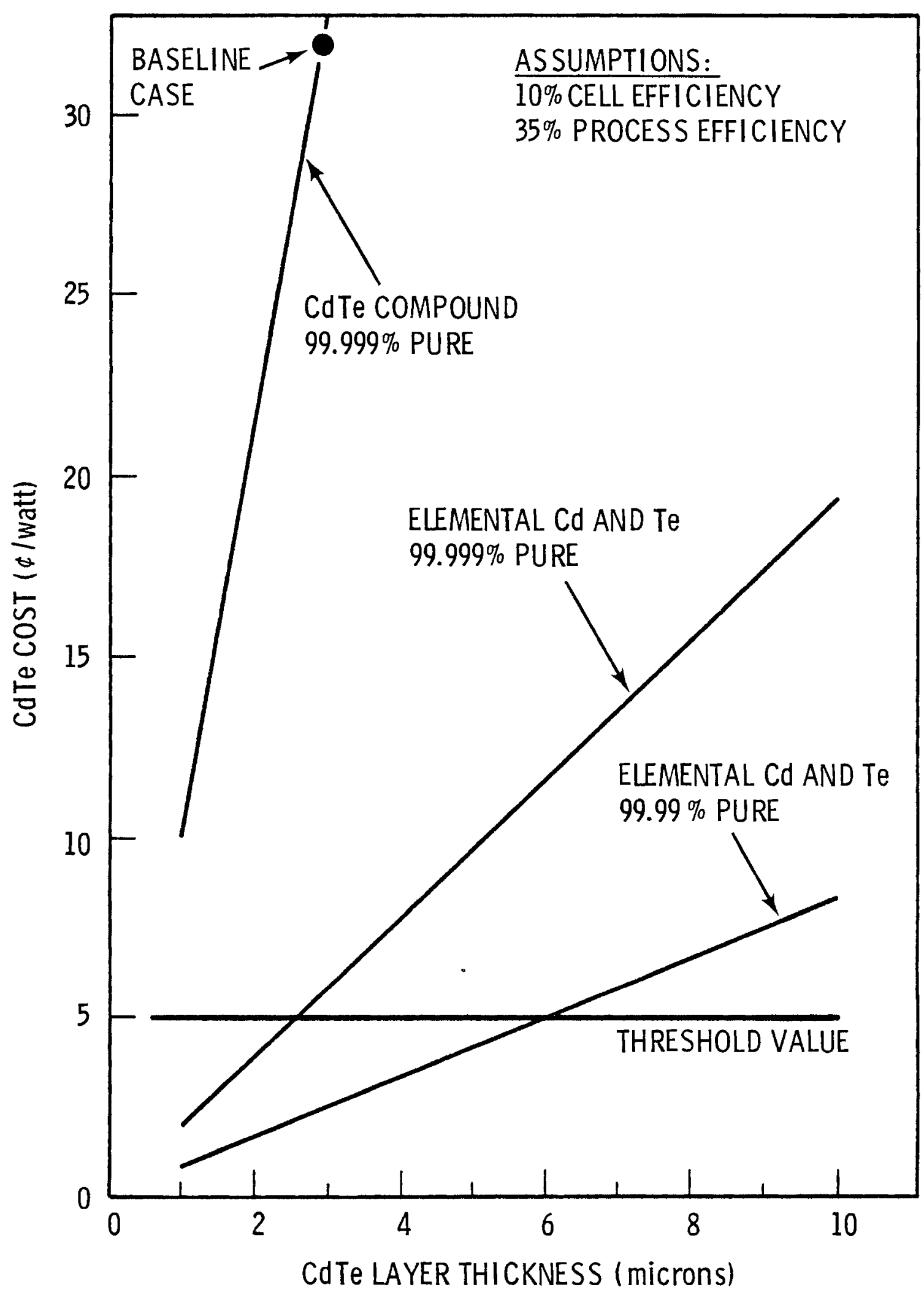

FIGURE 17. CdTe Material cost as a Function of Layer Thickness, Precursor Form and Purity 


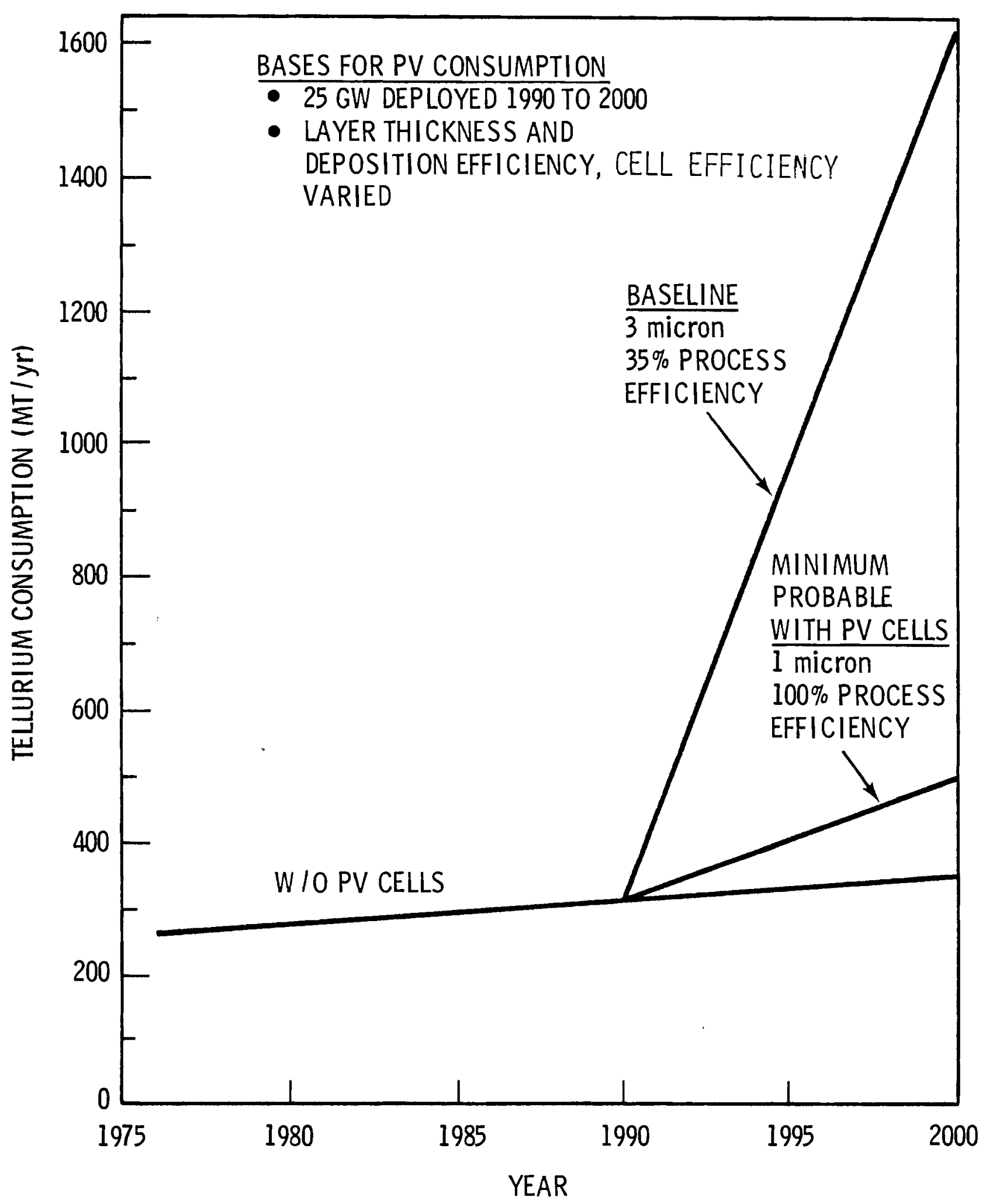

FIGURE 18. Projected llarket for Tellurium With and Without CdTe Ce11 Production 


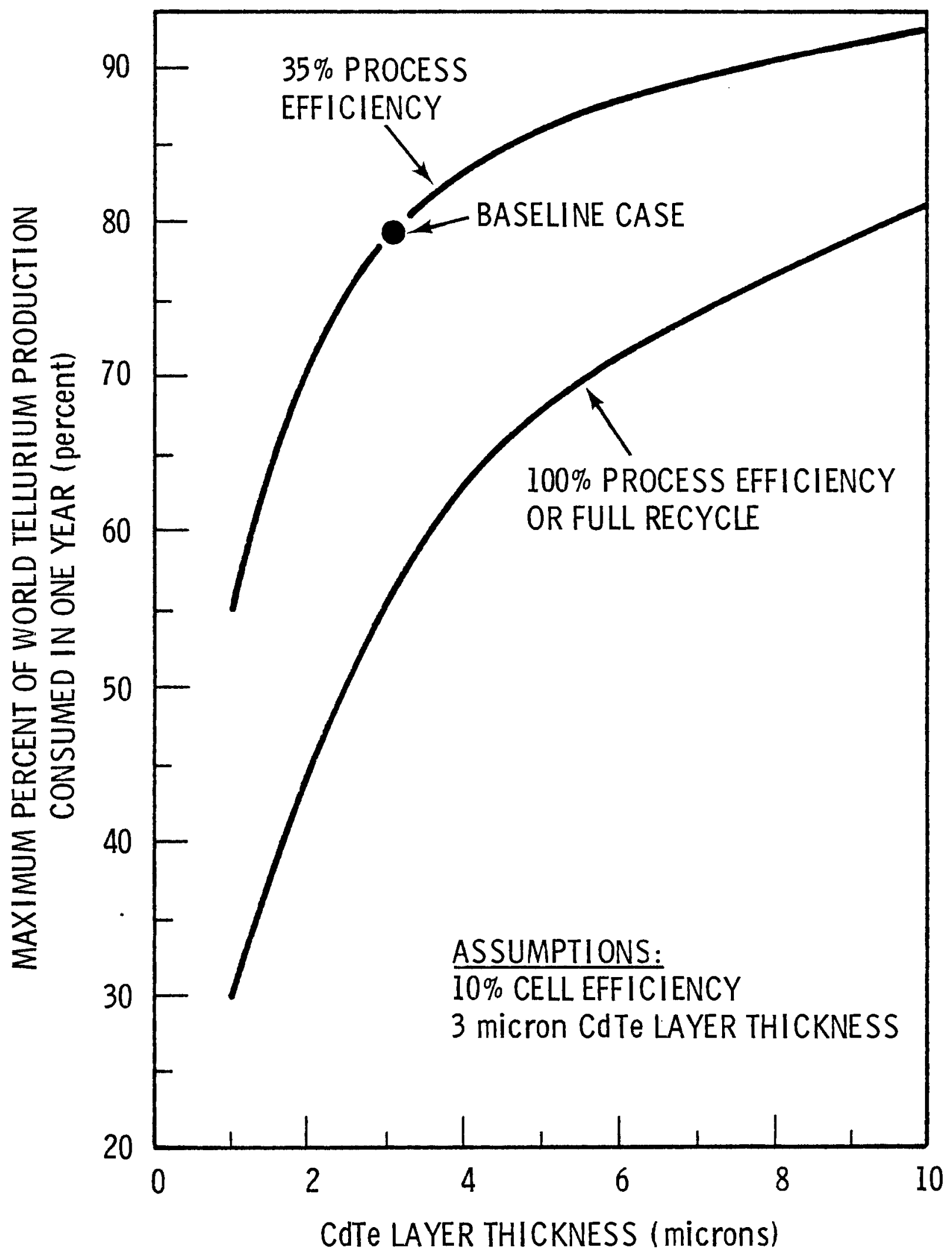

FIGURE 19. Maximum Share of World Tellurium Consumption Versus CdTe Layer Thickness and Process Efficiency 
some 310 MT more than the 1310 MT recovered at the rate of $0.065 \mathrm{~kg}$ per MT of anode copper (or a recovery efficiency of $33 \%$ ). The actual recovery rate of tellurium varies from year to year. The U.S. Bureau of Mines (1975) estimated recoverable domestic reserves based on a rate of $0.1 \mathrm{~kg}$ tellurium per MT (50\% recovery efficiency). If $0.1 \mathrm{~kg}$ tellurium were recovered from world primary copper production in the year 2000, some 2015 MT of tellurium would be produced which is sufficient to meet the combined world demand of 1620 MT.

Existing world refinery capacity is about 400 MT per year. Taken together the United States and Canada dominate world tellurium production. Lesser amounts are produced in Japan, U.S.S.R., and Peru. Tellurium supplies are adjusted by the producers to meet the relatively minor demand. Production costs are largely absorbed in the extraction of the maior products (precious metals). Under these conditions it would appear that world tellurium production capacity could be increased to meet photovoltaic demand if producers have sufficient lead time and an assured tellurium market to support the increased production capacity.

About $60 \%$ of world tellurium reserves are located in North and South America. The remaining world reserves are divided nearly equally between Europe, Africa, and Asia. In addition to the copper sources discussed, lesser amounts are available from lead and zinc refining and from gold. Very large resources of tellurium are contained in coal and oceanic manganese oxide modules. However, tellurium cannot be recovered economically as a primary product from these sources either. The estimated annual release of tellurium from the combustion of coal in the United States is only about 36 MT (U.S. Geological Survey 1973), and virtually all of this tellurium would be contained in the fly ash. Because of its geographic dispersion, the fly ash is likely to go to other uses such as a partial replacement for Portland cement. Although manganese oxide nodules contain area $30 \mathrm{ppm}$, tellurium availability from this source is difficult to predict.

In summary, there are problems with both price and availability of cadmium telluride and tellurium for deployment of 25 GWp cadmium telluride photovoltaic cells between the years 1990 and 2000. Tellurium supply is the most critical consideration. 
If cadmium telluride cells are to be deployed in volumes approaching 25 GWp, concerted efforts will have to be made which might include:

- Minimize the CdTe layer thickness.

- Communicate photovoltaic needs to tellurium producers at an early date.

- Improve the efficiency of tellurium recovery from anode slimes, without incurring significant cost increases.

- Execute long term supply contracts for tellurium (see InP discussion).

- Stockpile tellurium.

- Recycle al1 CdTe waste from cell fabrication.

- Increase the deposition process efficiency.

- Increase PV cell efficiency.

- Consider in-house production of cadmium telluride to directly control costs, delivery, and quality.

- Lower purity requirements to minimize cost.

- Consider the use of elemental tellurium and cadmium (or other alternatives) to minimize cost.

Al1 of the indium requirement for the cadmium telluride cell is contained in the indium-tin oxide, ITO ( In $1.9 \mathrm{Sn}_{0.1} \mathrm{O}_{3}$ ) window layer. The problem here is availability, not cost. The ITO and In costs are on ly 1.2 and 1.0 cents/watt, respectively, based on a price of $\$ 10 /$ troy $0 z$ for indium. (From 1947 to 1973 , the price was nearly constant at $\$ 2.50 /$ troy oz, and is currently $\$ 17 /$ troy oz.). The indium price would have to be over $\$ 40 /$ troy oz before indium cost would reach $\$ .05 /$ watt threshold.

Indium 0xide (and indium-tin oxide) is currently produced in small quantities, essentially on demand. It is probably not imported. Indium oxide is made by the thermal decomposition of indium nitrate which can be obtained by dissolving indium metal in nitric acid. This is a relatively well developed, simple flowsheet which means that increasing indium oxide production would not be difficult. A small amount of tin oxide $\left(\mathrm{Sn}_{2} \mathrm{O}_{3}\right)$ is added to obtain ITO. Indium-tin oxide requirements for cadmium telluride cells are projected to 
expand to about 160 MT per year by the year 2000. If sufficient indium is available, sufficient supplies of indium oxide could be made available through cooperative planning between indium suppliers and the PV cell manufacturers. It may be necessary to enter into long-term supply agreements (see InP discussion). Of course, no amount of planning for ITO production would compensate for a lack of indium. The availability of indium is the principal question here.

Deployment of $25 \mathrm{GW}$ of cadmium telluride cells by the year 2000 will require a maximum indium demand growth of $21 \%$ per year. About 130 MT (56\% of the wor ld demand) of ind ium would be used in cadmium telluride cells in the year 2000, as illustrated in Figure 20. A cumulative total of 720 MT of indium would be required for cadmium telluride cells. Current U.S. indium production from U.S. ores is less than 3 MT per year.

A detailed discussion of indium supply problems is contained in a previous report (watts et al. 1980). The remainder of this discussion will be devoted to sumarizing indium supply problems relative to cadmium telluride cell requirements.

Indium is about as abundant as silver in the earth's crust. It is a byproduct of zinc refining, therefore the amount available depends upon zinc production. There are no deposits with sufficient concentration to process indium alone. During zinc refining indium becomes concentrated in residues from retorts, and zinc anode slimes from which the indium is economically recoverable. Approximately $90 \%$ of the indium could be recovered from indiumrich residues; however, the overa 11 recovery from zinc ores is $40 \%$. Just how much of the available residues are being processed from indium recovery is unknown.

Three companies produce indium domestically. They are The Indium Corporation of America, its partner, New Jersey Alloy, and American Smelting and Refining Company. Canada is the main source of indium imports. Cominco, Ltd. is the only Canadian producer. A small percentage of foreign zinc plants 


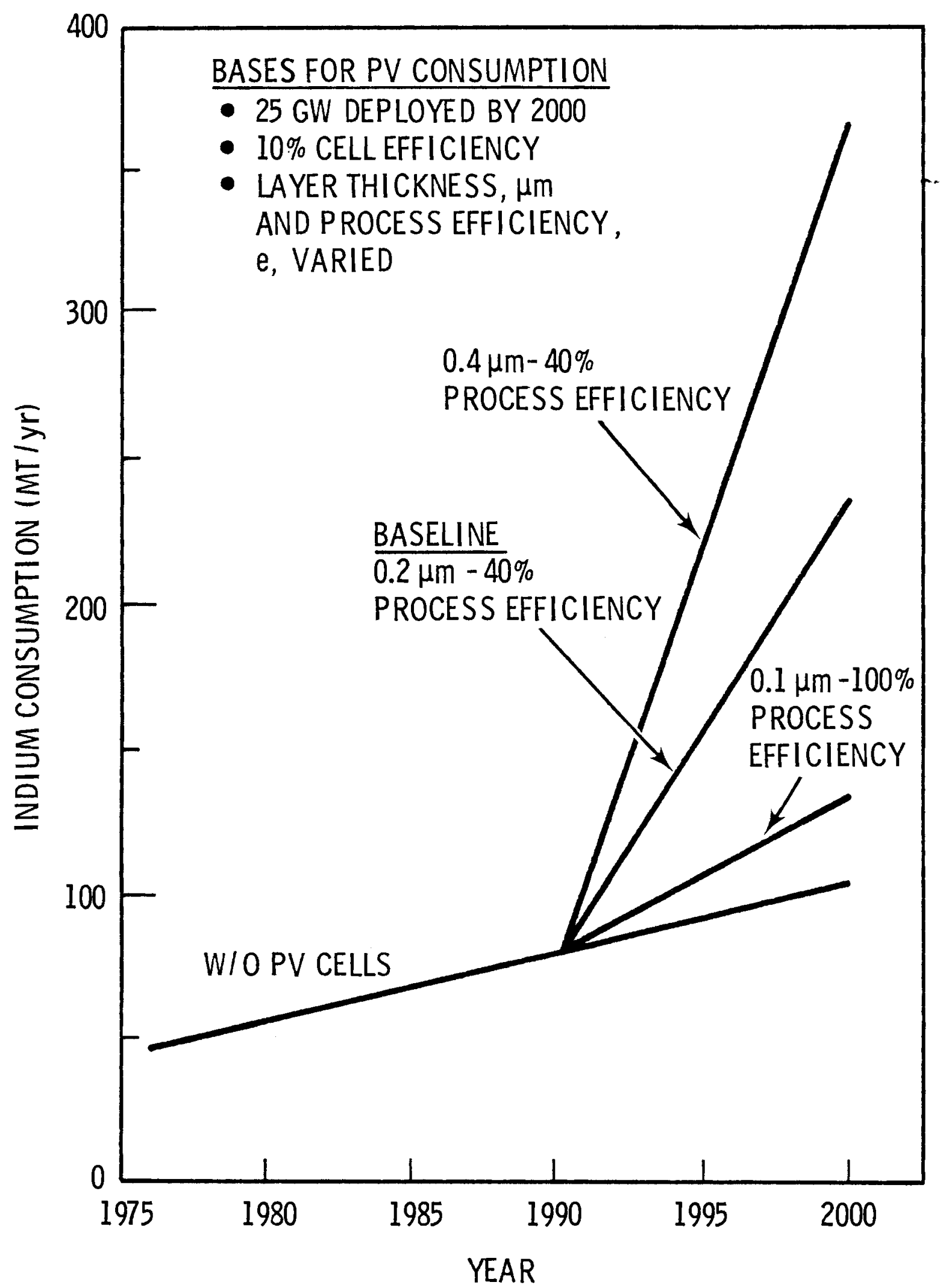

FIGURE 20. Projected Market for Indium With and Without Cadmium Telluride PV Cell Production 
produce indium. Production levels and stocks are largely unknown (company confidential).

The U.S. Bureau of Mines estimated 1973 world production at 54 MT, and refinery capacity at 128 MT. As was shown in Figure 20 , world indium consumption, the baseline cadmium telluride, with cells, is projected to be 233 MT in the year 2000 ( 130 MT for CdTe cells). Whether or not that indium production level is attained depends upon the indium content of zinc ores being processed that year. Domestic production in the year 2000 is estimated at 7 MT based on projected zinc capacity, current indium recovery processes, and estimated indium concentrations. This would indicate that the majority of U.S. indium will come from imports and stockpiles of metal and concentrates.

The indium content of zinc ores is highiy variable. Most ores are not assayed for indium. Hence, the knowledge of world reserves and resources is poor. In the U.S. there is a shift towards zinc ores having lower indium contents. Estimates of U.S. indium reserves range from 300 to 1800 metric tons with additional resources of 300 to 5400 metric tons. Deployment of $25 \mathrm{GW}$ of the baseline cadmium telluride cells will require 720 MT of indium.

The U.S. Burea of Mines estimated (in 1975) that world reserves of indium were 1500 MT with almost 1900 MT of additional resources.

It is clear that world indium supplies may not be sufficient for the projected cadmium telluride solar cell requirements. From the material supply viewpoint, the use of indium-tin oxide should be reduced or eliminated. The ITO layer might be thinned from 0.2 to 0.1 microns. Total ITO use could be reduced by increasing the solar cell efficiency above $10 \%$ or by increasing the efficiency of the ITO layer deposition process above $40 \%$. Perhaps the $60 \%$ wasted ITO could be recycled, thus cutting the net indium use in half or less. At $\$ 10$ per troy oz of indium recycling of ITO plated out on masks, chamber walls, and cold traps could be economically attractive. For cadmium telluride cells, a minimum yearly indium requirement of 17 MT in the year 2000 (or 96 MT total for $25 \mathrm{GW}_{\mathrm{p}}$ produced during the 10 year span 1990 to 2000) could be arrived at by reducing layer thickness from 0.2 to 0.1 microns, increasing cell efficiency from $10 \%$ to $15 \%$, and by recycling all of the indium not deposited in 
the cells. This minimum requirement of $17 \mathrm{MT}$ is still more than twice the 7 MT est imated domestic production in the year 2000 .

An alternate to ITO for the conductive window layer is tin oxide $(0.2$ micron thick) with an aluminum grid $(0.5$ micron thick). This substitution completely removes ITO and indium from the cell, along with their supply problems. The tin oxide/aluminum substitution has no known supply problems since production dwarfs cadmium telluride cell requirements and material costs are low. It is recormended that the use of ITO be eliminated in favor of tin oxide with aluminum grid (or any other non-critical alternate).

If it is found that the use of ITO is the preferred option, the indium supply situation might be improved by several actions. Indium suppliers and PV cell fabricators should plan 5 to 10 years in advance for PV ce 11 requirements. Stockpiling of indium would be wise. Long-term supply contracts would encourage indium producers to enlarge capacity and seek additional sources (see InP discussion). Some work should be done to improve the efficiency of indium recovery from zinc processing by upgrading present processes or developing new processes. Finally, more knowledge of U.S. and world indium reserves and resources is needed. Efforts should be made to obtain indium assay data for a!l zinc ores and concentrates. Exploration for additional resources should also be done.

For 25 GWp of the baseline cell a total of 17,250 MT of cadmium sulfide would be required. In the year 2000 , about 3100 MT or $27 \%$ of the projected world production of cadmium sulfide would be required for this PV cell. These quantities are based on the baseline values for layer thickness ( 5 microns), deposition efficiency (35\%) and cell efficiency (10\%).

Figure 13 shows the relationship between the possible range cadmium sulfide layer thicknesses and the maximum percent of world production consumed by the indium phosphide/cadmium sulfide cell in one year. Four different cases are presented: the baseline case, the sensitivity case and two cases showing the results of recycling of the cadmium sulfide lost in the evaporation process. The $10 \%$ reference line indicates the threshold level used in the CMAP program. 
If the thickness of the cadmium sulfide active layer could be reduced to less than 2 microns (in the 10\% cell efficienty case), photovoltaics consumption of this material should not have a severe impact on the world cadmium sulfide market. Likewise, if the cell efficiency could be improved to $15 \%$ and if all of the cadmium sulfide lost during evaporation were recycled the layer thickness could remain at 5 microns and still not impact the world market. However, if the cadmium telluride/cadmium sulfide were to use more than $10 \%$ of the world production in one year, the price of cadmium sulfide may increase substantially and hinder achieving the desired cost goais.

Therefore it is recommended that the work be directed towards increasing the overall cadmium tellurdie/cadmium sulfide cell efficiency and recycling of the lost cadmium sulfide. Also, onsite production of cadmium sulfide should be considered to ensure the desired level of purity.

If the CdS layer thickness were increased from the baseline 5 microns to 20 microns, two things happen in addition to straining the production capacity for cadmium sulfide: 1) at 20 micron thickness and a cadmium sulfide price of $\$ 11 / 1 \mathrm{~b}$, the CdS cost is $\$ .07 /$ watt which is a major portion of the $\$ .40 /$ watt cost goals of DOE, and 2) at 20 micron thickness PV cell consumption of cadmium metal becomes significant relative to supplies. This potential problem is compounded if cadmium telluride layer is also increased in thickness. At the maximum probable thicknesses of 20 micron (versus 5 micron baseline) for CdS and 10 micron (versus 3 micron baseline) for CdTe a total of 75,940 MT of cadmium are required to build 25 GWp of cells (at $10 \%$ cell efficiency and $35 \%$ process efficiency). The maximum one year requirement is 13,670 MT which represents $27 \%$ of the projected world consumption of cadmium in the year 2000. Even under these conditions, it appears that requirements for solar cell production could be accomodated.

Proven world cadmium reserves in 1976 were reported to be almost 700,000 metric tons. When this figure is combined with potentially economic cadmium ores, the total resources jump to 18.125 million metric tons. By the year 2000 total nonsolar consumption has been forecast to be 37,000 metric tons and only about 13,000 metric tons would be utilized in the PV sector in that year. 
In addition to sufficient future supplies of cadmium, there is minimal risk of this supply being disrupted by cartels. The U.S. controls $30 \%$ of all world proven reserves, while another $30 \%$ are distributed among major industrial noncommunist countries. Further, the U.S. General Services Administration stockpiles cadmium.

Therefore, cadmium should not be viewed as a constraint in the development and production of cadmium-based solar cells.

"B" Material Discussion

The following "B" materials were reviewed and found not to constrain the deployment of cadmium telluride solar cells. Generally, they are used in relatively small amounts and their cost to solar is low. Therefore, only severe supply disruptions, if they were to occur in the future, would significantly impact polycrystalline silicon solar cells. Supplies are adequate and stable. No supply disruptions are foreseen. These "B" materials should be subjected to periodic review.

Cadmium, ferromanganese, tin, zinc, flourspar, managanese ore, and zinc ore are classified as "B" materials because they are $53 \%$ to $98 \%$ imported. There is an interesting relationship between zinc and its byproducts cadmium and indium. A total of 18,897 MT of zinc must be processed to win the cadmium and indium requirements for $25 \mathrm{GW}$ of baseline cadmium telluride cells. The cells require 20,422 MT of zinc. Therefore, if the zinc (and zinc ore) are available, cadmium and indium availability should be assured.

Petroleum coke is a byproduct of petroleum refining, and its supply is dependent upon continued petroleum refining. For this reason it is classified as a "B" material.

Petroleum is classified as a "B" material simply because U.S. reserves are small. However, U.S. resources are much larger. Imports, synfuel production, and reserves to be developed should assure availability of petroleum for the very small solar requirements.

Bauxite, chromite, fluorspar ore, and tin ore are "B" materials because they are largely imported and U.S. reserves and resources are small. 


\section{COPPER INDIUM SELENIDE SOLAR CELL}

\section{Cell Description}

Figure 21 illustrates the most successful design to date for a solar cell employing a hetrojunction of $\mathrm{CuInSe}_{2}$ with CdS. The active layers of the cell are deposited on Mo-coated alumina $\left(\mathrm{Al}_{2} \mathrm{O}_{3}\right)$ or, alternatively, soda lime glass 0.125 inches thick. The Mo is sputter deposited with a thickness of 0.3 um using a Mo target. A $2.5 \mu \mathrm{m}$ thick p-type CuInSe ${ }_{2}$ layer is coevaporated on to the Mo using bulk $\mathrm{Cu}$, In and Se sources, the composition controlled by the relative amounts of $\mathrm{Cu}$, In and Se which are evaporated. A higly doped $\mathrm{p}^{+} \mathrm{CuInSe}_{2}$ layer, $0.8 \mu \mathrm{m}$ thick, is evaporated onto the p-type CuInSe 2 layer. Doping is accomplished by varying the stoichiometry of the deposit. A $\mathrm{p}^{+} \mathrm{CdS}$ layer with a thickness of $0.8 \mu \mathrm{m}$ is then evaporated using a CdS source and a $1.7 \mu \mathrm{m}$ thick In-doped CdS layer is evaporated onto the $\mathrm{p}^{+} \mathrm{CdS}$. The In concentration is 3 wt.\% or $6 \times 10^{21}$ In atoms $/ \mathrm{cm}^{3}$. An Al contact grid having a thickness of $2 \mu \mathrm{m}$ is evaporated on to the top CdS layer using an A1 source.

The active CuInSe 2 layers may possibly be replaced by $\mathrm{CuIn}_{0.3} 3^{\mathrm{Ga}_{0}}{ }_{0.7}$ $\mathrm{Se}_{1.2} \mathrm{Te}_{0.8}$. Cells have been fabricated using a polycrystalline pressed disc of $\mathrm{CuIn}_{0.3}{ }^{\mathrm{Ga}} 0.7^{\mathrm{Se}_{1.2}} \mathrm{Te}_{0.8}$ with $\mathrm{CdS}$ evaporated onto the disc. Sputtering and evaporation of $\mathrm{CuIn}_{0.3} 3^{\mathrm{Ga}_{0}} .^{\mathrm{Se}_{1.2} \mathrm{Te}_{0.8}}$ are still in the developmental stages.

Currently, complete cell structures include an $800 \AA$ thick sio $(n=1.9)$ quarter wavelength antireflective coating tuned near $600 \mathrm{~nm}$. This layer is usually evaporated using bulk SiO.

In Figure 21 , the CuInSe 2 /CdS heterojunction cel1 is used to illustrate materials requirements for $\mathrm{CuInSe}_{2}$ solar cells, including alternate materials. Representative deposition processes and associated feedstock materials are shown in conjunction with the range of process efficiencies considered typical for each process. Layer thicknesses designated as "most likely" are based on current state-of-the-art $\mathrm{CuInSe}_{2}$ and $\mathrm{CuIn}_{0.3}{ }^{\mathrm{Ga}_{0}} .^{\mathrm{Se}_{1.2} \mathrm{Te}_{0.8}}$ solar cells. A $10 \%$ cell conversion efficiency was assumed for the baseline cell. Deposition processes have been discussed elsewhere (R. L. Watts et al. 1979). 


\section{CulnSe ${ }_{2}$ SOLAR CELL}

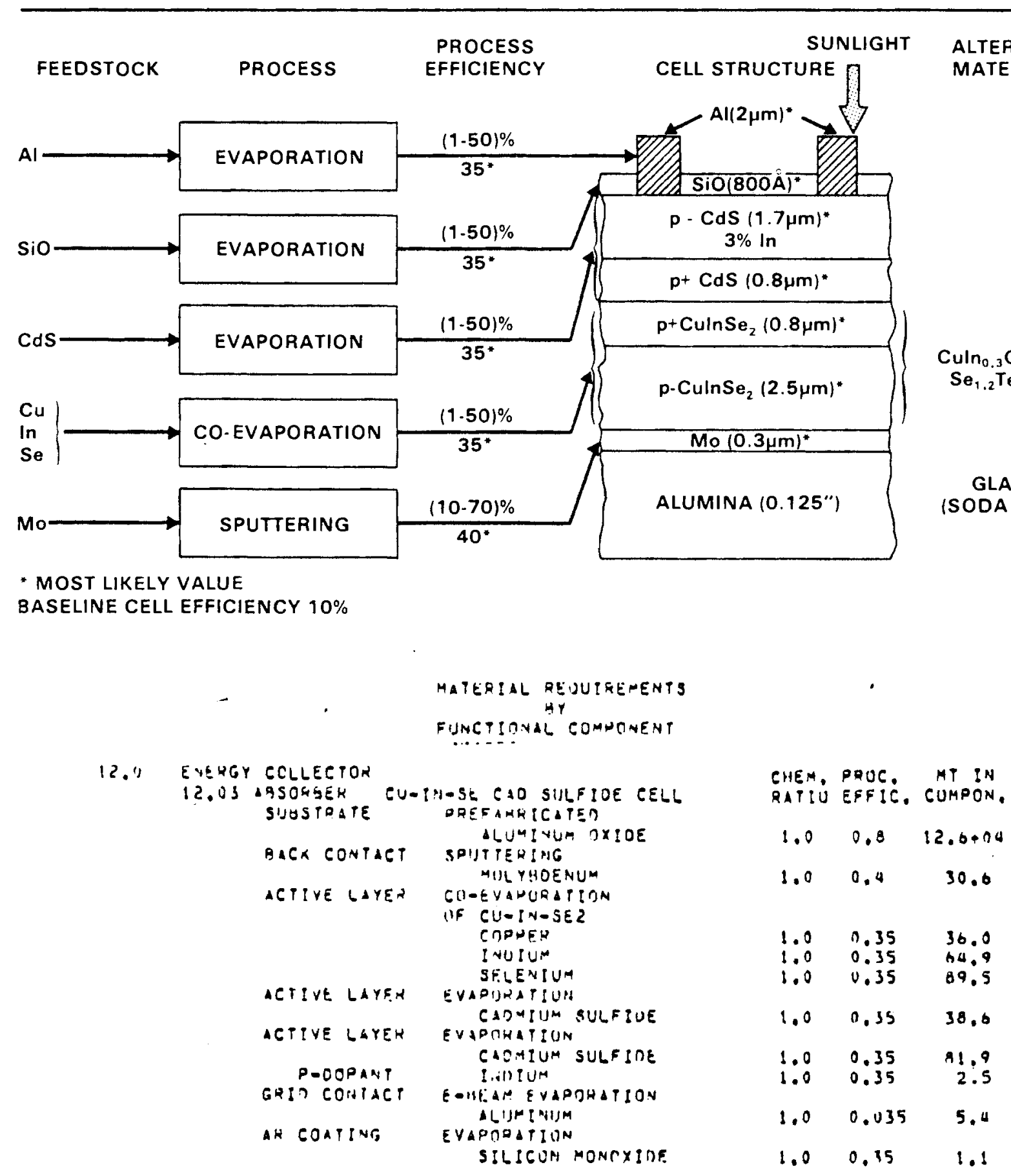

FIGURE 21. The Baseline Copper-Indium Selenide Cadmium Sulfide Heterojunction Solar Cell 
Screening Results

Review of the CMAP screening of the baseline (see Table 10) copper indium selenide solar cell identified the following "A" materials:

Baseline

Indium

Selen ium

Cadmium Sulfide

and the following "B" materials

Cadmium

Petroleum coke

Ferromanganese

Zinc

Fluorspar

Hydrochloric acid

Bauxite

Chromite

Fluorspar ore

Manganese ore

Zinc ore

Zinc byproducts

Nickel ore

Petroleum

Silicon (Seg)

silicon monoxide

"A" Material Discussion

The baseline characterization of the copper indium selenide cell uses 4814 MT indium between 1991 and 2000, requiring a production growth rate of $122 \%$, consuming $89 \%$ of wor ld indium production in one year at a cost of $\$ .064 /$ watt. It is therfore classified as an "A" material.

The impact of varying the thickness of the active layer from 1 to 5 microns, the coevaporation process efficiency from $35 \%$ to $100 \%$ and the 

TABLE 10. Bulk Material Requirements for: Copper-Indium Selenide/
Cadmium Sulfide Heterojunction Baseline

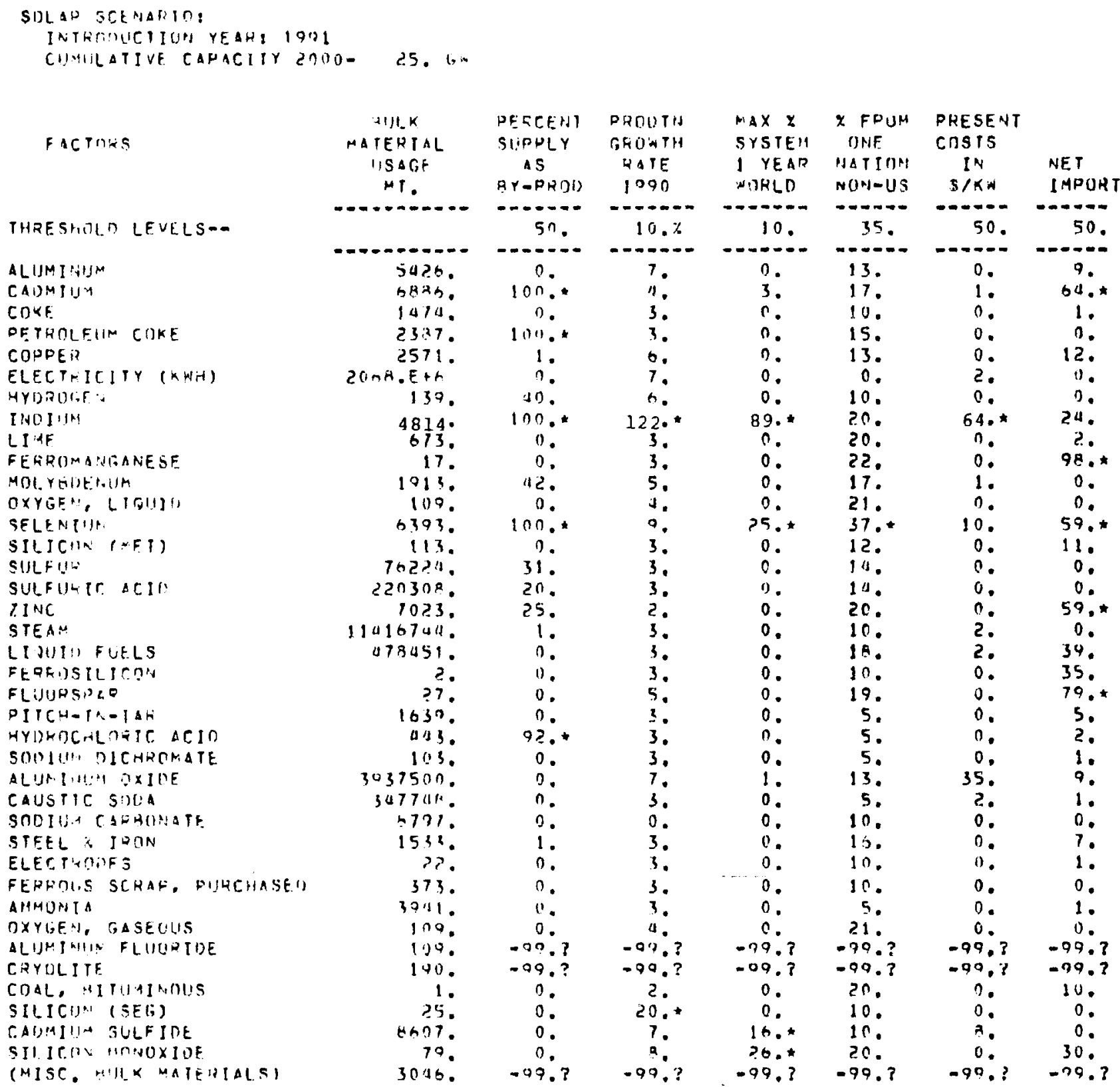


TABLE 10. (continued)

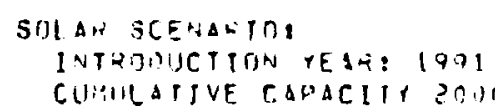

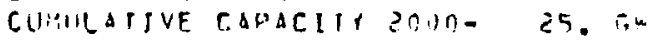

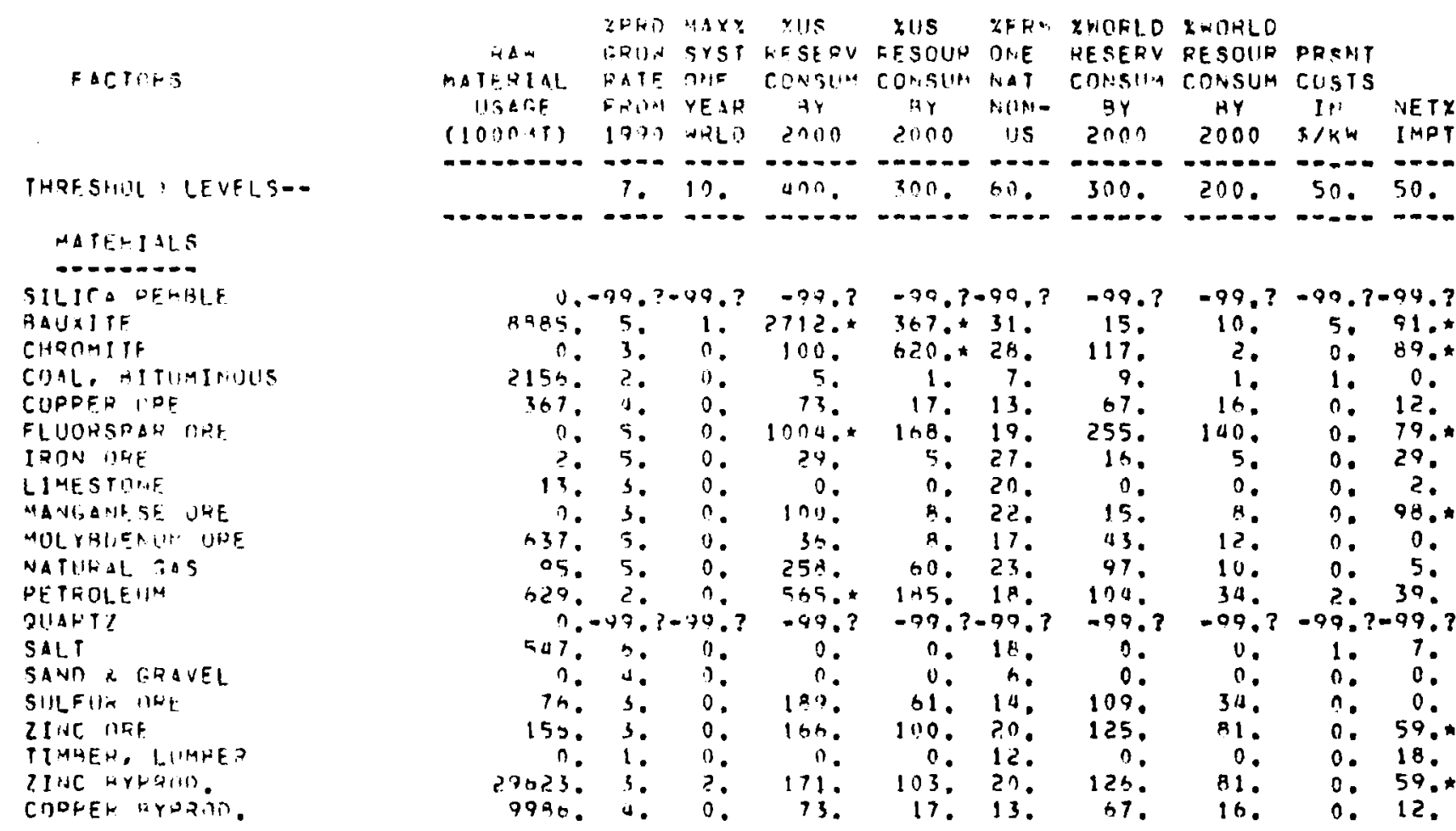


present cost in cents/watt is depicted in Figure 22. Assuming a $\$ .05 /$ watt present cost threshold level (i.e. $\$ 50 / \mathrm{KW}$ ), the thickness of the active layer would have to be reduced to less than 3.0 microns in order for the indium cost to be less than this threshold level if $25 \mathrm{GW}_{p}$ of this cell were deployed by 2000. An alternative would be to recover a 11 of (i.e., 100\% process efficiency) the indium lost in the coevaporative process if technically and economically feasible.

A detailed discussion of indium supply problems is the subject of $R$. $L$. watts et al. (1980). The following is a summary of indium supply problems relative to the requirements of the copper indium selenide cell.

Indium is about as abundant as silver in the earth's crust. It is a byproduct of zinc refining, therefore the amount available depends upon zinc production. There are no deposits with sufficient concentration to process for indium alone. During zinc refining indium becomes concentrated in residues from retorts, and zinc anode slimes from which the indium is economically recoverable. Approximately $90 \%$ of the indium could be recovered from the indium rich residues; however, the overall recovery from zinc ores is about 40 percent. Just how much of the available residues are being processed for indium recovery is unknown.

Three companies produce indium domestically. They are The Indium Corporation of America, its partner, New Jersey Alloy, and American Smelting and Refining Company. Canada is the main source of indium imports. Cominco, Ltd. is the only Canadian producer. A small percentage of foreign zinc plants produce indium. Production levels and stocks are largely unknown (company confidential).

The U.S. Bureau of Mines estimated 1973 world production at 54 MT, and refinery capacity at 128 MT. Figure 23 shows indium consumption over time for both solar and non solar applications. A cell conversion efficiency of $10 \%$ and an active layer thickness of 3.3 microns was assumed. World indium consumption with the copper indium selenide cell ranges from $970 \mathrm{MT} /$ year to $395 \mathrm{MT} /$ year in 2000. Domestic production in the year 2000 is estimated at 7 MT based on projected zinc capacity, current indium recovery processes, and est imated indium 


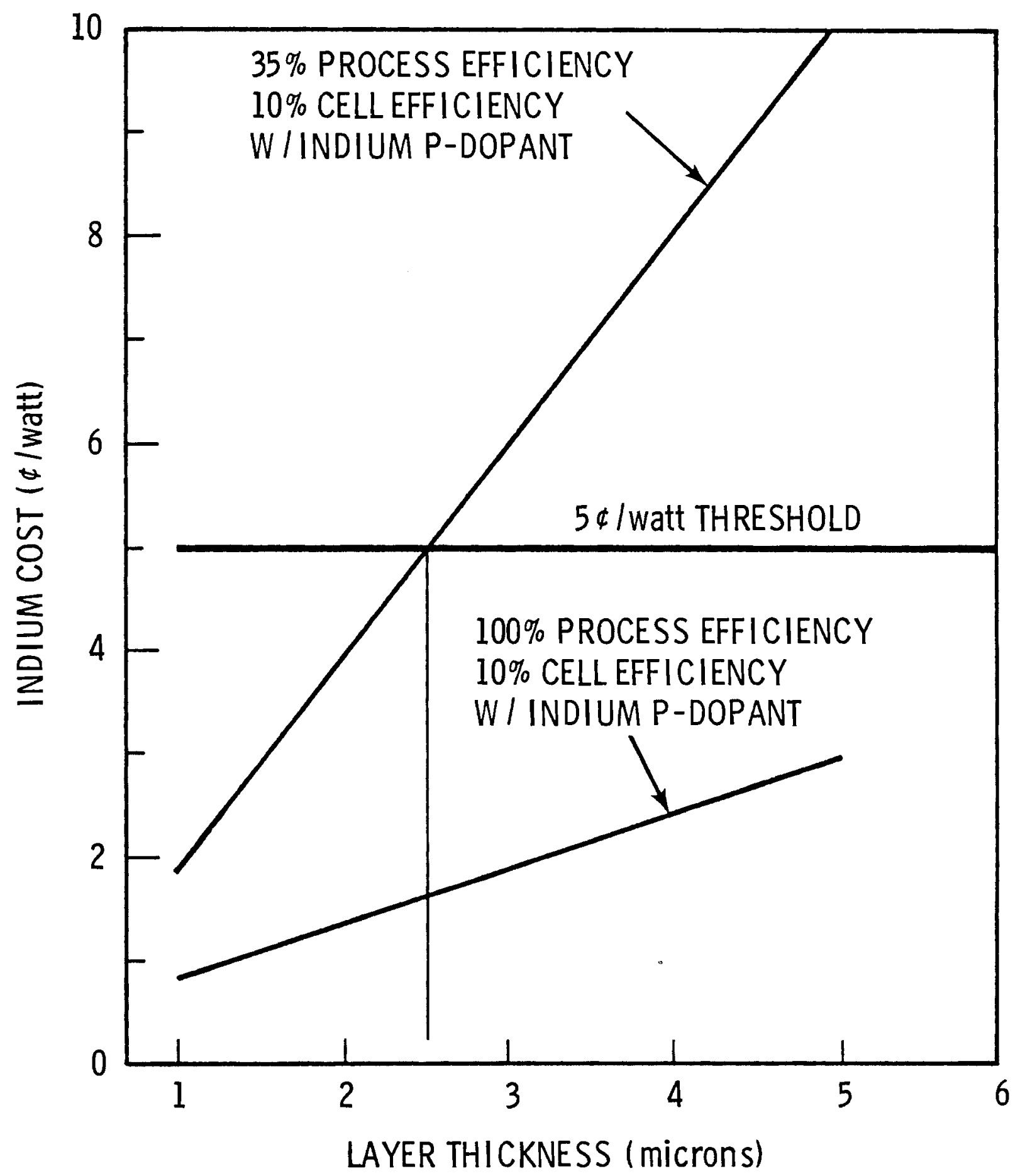

FIGURE 22. Indium Present Costs Versus Active Layer Thickness and Coevaporation Process Efficiency 


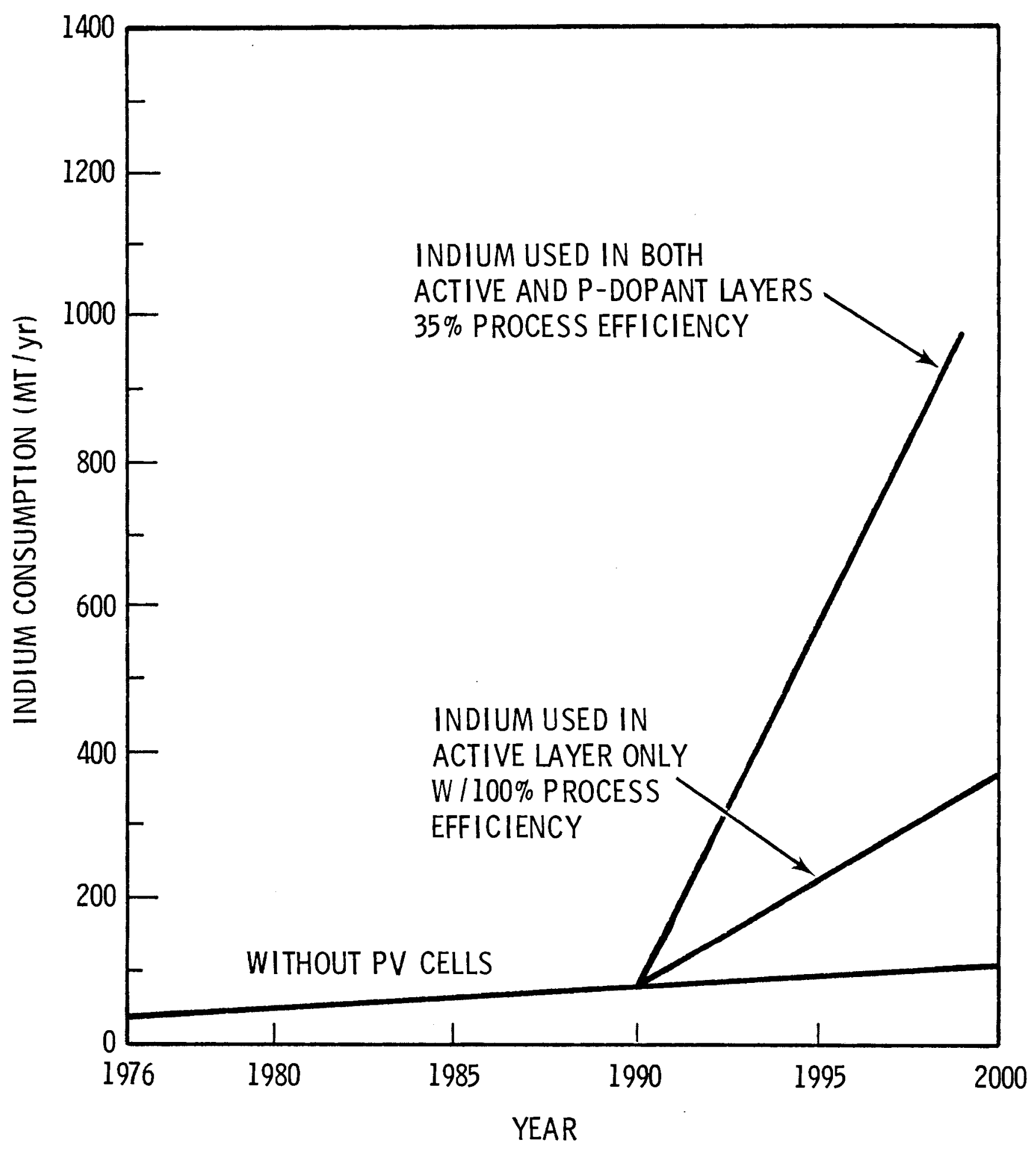

FIGURE 23. Projected Market for Indium With and Without Copper Indium Selenide PV Cell Production 
concentrations. U.S. indium consumption (without solar) is estimated to be 47 MT in 2000. This would indicate that the majority of U.S. indium will come from imports and stockpiles of metals and concentrates.

The indium content of zinc ores is highly variable. Most ores are not assaved for indium. Hence, the knowledge of world reserves and resources is poor. In the U.S. there is a shift towards zinc ores having lower indium contents. Estimates of U.S. indium reserves range from 300 to 1800 metric tons with additional resources of 300 to 5400 metric tons.

Deployment of $25 \mathrm{GW}$ of the copper indium selenide cell will require 4814 MT of indium under baseline conditions.

The U.S. Bureau of Mines estimated (in 1975) that world reserves of indium were 1500 MT with almost 1900 MT of additional resources.

It is quite apparent that the baseline characterization of the copper indium selenide cell will encounter severe indium supply constraints if it is deployed on a large scale. We recommend that work be directed towards reducing the thickness of the active layer to less than 3.0 microns. Work should also be directed towards assessing the feasibility of recycling the indium lost during coevaporation.

Selenium is classified as an "A" material since the copper indium selenide solar cell would require 6393 MT and would consume $25 \%$ of the world's selenium production in one year. However, at a cost of $\$ .01 /$ watt, selenium should not present a cost constraint to this cell.

The relationship between the range of likely thicisnesses of the copper indium selenide active layer, process efficiencies and the corresponding maximum percent of world selenium production consumed in one year is presented in Figure 24. The 10\% reference line for PV cell consumption is included to the threshold level set for this criteria in CMAP. For the baseline cell (i.e., $10 \%$ cell conversion efficiency and 35\% process efficiency) the thickness of the copper indium selenide layer would have to be reduced to about 1 micron before this cell's consumption of world selenium production falls below the $10 \%$ threshold level. The second case presented assumes that all of the selenium lost 


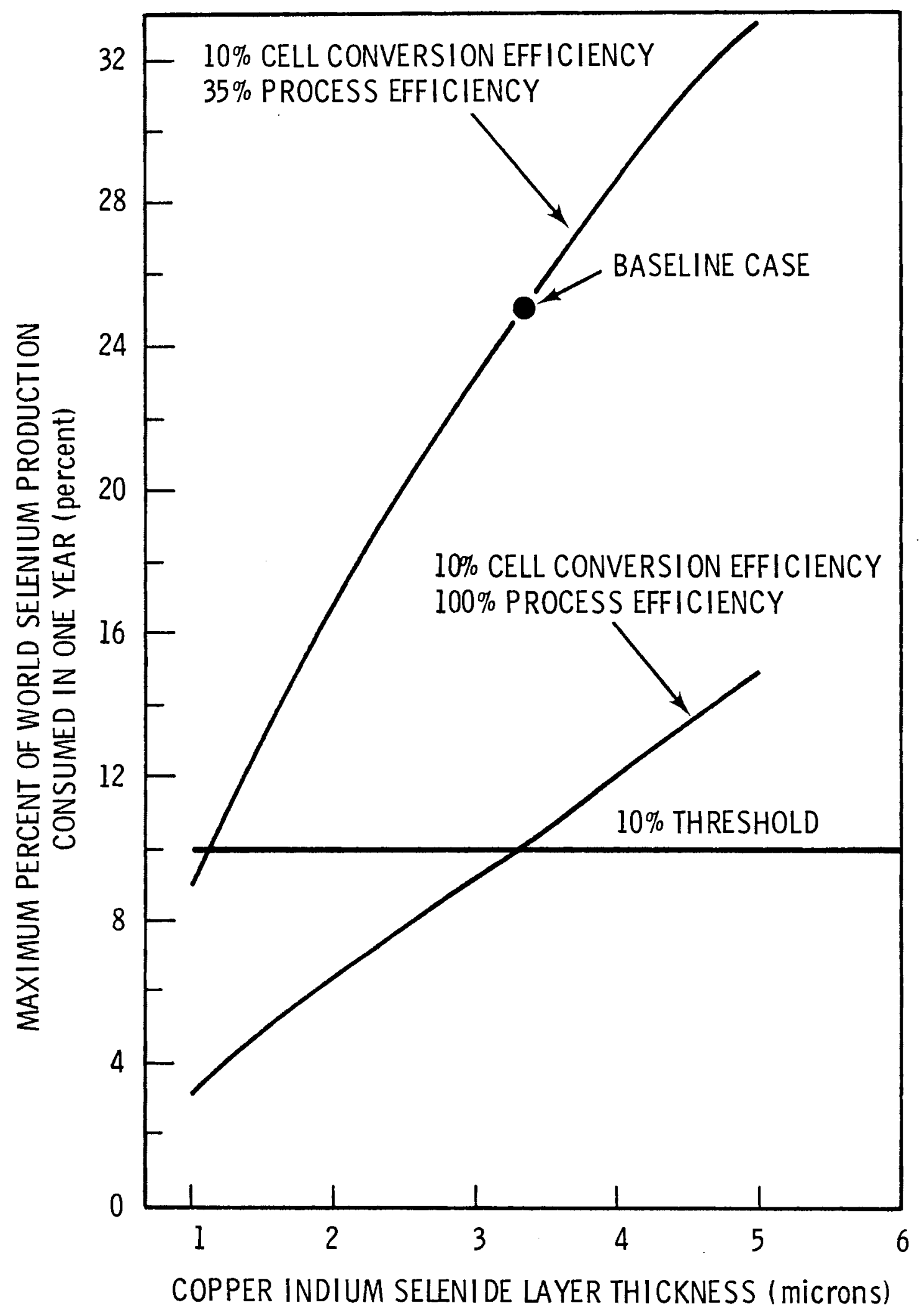

FIGURE 24. Copper Indium Selenide Layer Thickness and Process Efficiency versus Maximum Percent of World Selenium Production Consumed in One Year 
during deposition can be recovered. In this case, the consumption of selenium reaches the $10 \%$ threshold level at 3.3 microns.

Selenium is currently produced as a byproduct of processing copper anode slimes by 22 corporations in 13 countries, including the U.S. Major U.S. refined selenium producers are ASARCO Inc., Amax Copper and Kennecott Corp. However, the U.S. has relied heavily on selenium imports from Canada. Other U.S. resources of selenium include: coal, 1.5 parts per million (ppm), and sedimentary uranium and phosphatic vanadium deposits, 200 to $300 \mathrm{ppm}$. Unfortunately, the quantities of selenium available from these sources are small or are not likely to become economically feasible to recover in the future.

Major end uses of selenium in the U.S. are:

- electronic components - photoelectric and xerographic uses,

- semiconductors, glass-tinting,

- chemicals-plastics, inks, paint;

- animal food supplements-disease control.

The availability of adequate supplies of selenium for PV cells at reasonable prices depends upon the growth in consumption of the nonsolar end use sectors. The Bureau of Mines provides a range of consumption estimates by end use sector for the year 2000 (Table 11). To these estimates are added the

TABLE 11 Projected U.S. Selenium Consumption By End Use (metric tons)

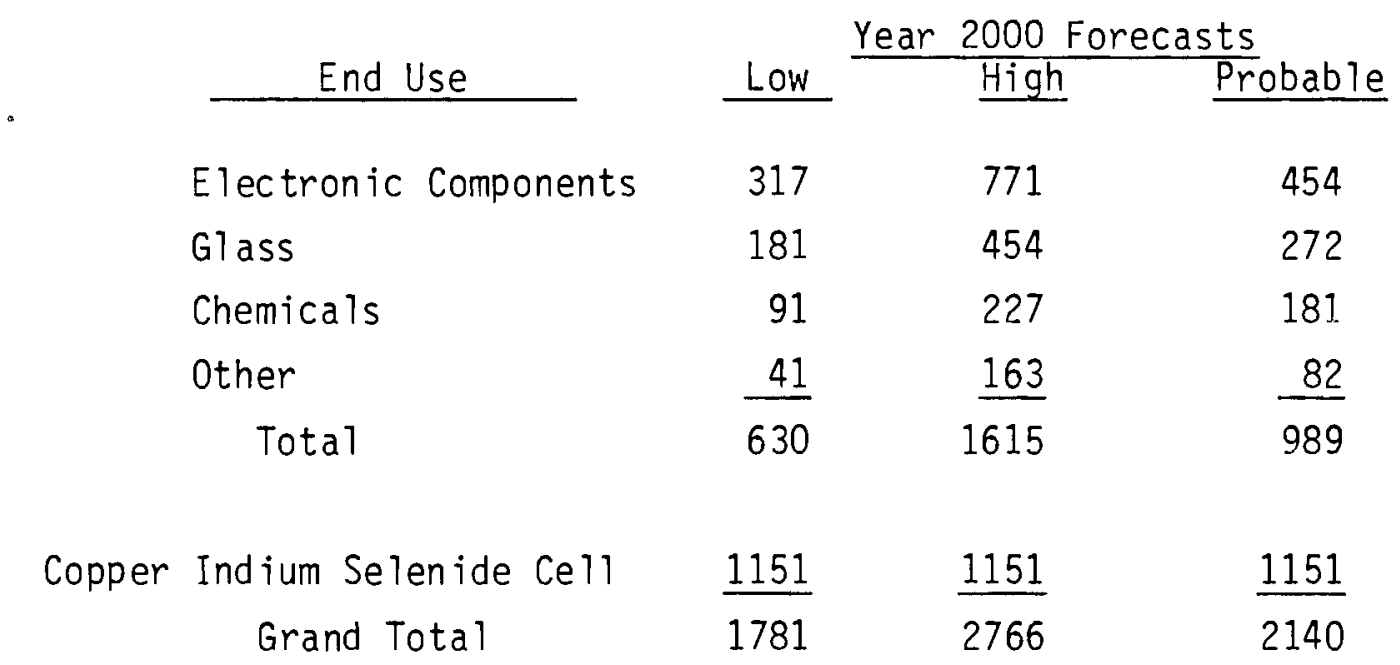

Source: J. R. Loebenstein, World Production, Consumption, and Future Trends of Selenium and Tellurium . Bureau of Mines, U.S. Department of Interior, Washington, D.C. 
selenium consumption (1151 MT) of this PV cell in the year 2000. U.S. projections for solar and nonsolar uses of selenium range from 1781 MT to 2766 MT in 2000 .

Bureau of Mine projections of domestic selenium production for 2000 are a low of 1270 MT, probable of 1451 MT and a high of 1633 MT. These production estimates assume that $85 \%$ (maximum potential recovery) of contained selenium is recovered from copper anode slimes. Current practice yields an average of $52 \%$ recovery. However, copper and selenium data suggest a current peak production capability to recover 80 to $85 \%$ of the selenium content of copper anodes (U.S. Bureau of Mines 1975). Comparing the U.S. production and consumption (including solar) estimates for 2000 indicates that the U.S. will still be relying on imports to meet domestic selenium needs, and that solar will require a substantial portion of domestic selenium production in 2000 .

The Bureau of Mines estimates world selenium consumption in the year 2000 at about 3500 MT. If the copper indium selenide cell requirements of 1151 MT are added, the total world consumption in 2000 is 4651 MT of selenium. Based on projected production of primary copper, the amount of selenium potentially produced in the year is either 5300 MT at $52 \%$ recovery efficiency or 8700 MT at $85 \%$ recovery efficiency. Thus is appears that sufficient selenium could be made available for the baseline copper indium selenide cell, if sufficient production capacity exists. If selenium production capability is not adequate to meet the requirements for PV cells, the price of selenium will rise rapidly and the cost of selenium for PV cells will be prohibitive.

We recommend that work be directed towards reducing the thickness of the copper indium selenide layer to less than 3.3 microns increasing cell efficiency and recovering the selenium lost in the coevaporation deposition process.

If selenium cannot be recycled then the layer deposition efficiency should be raised. Selenium suppliers and photovoltaic cell fabricators should plan we 11 in advance for PV requirements by stockpiling or executing long-term supply contracts (see InP discussion). Efforts should be made to increase the quantity of selenium recovered from anode slimes. 
Cadmium Sulfide as used in the $P$ and $P^{+}$active layers of the copper indium selenide cell, would require $16 \%$ of the world's cadmium sulfide production in one year and may present future availability problems. The costs of the cadmium sulfide, at $\$ 8 / \mathrm{Kw}$, should not present an obstacle to the copper indium selenium cell.

Figure 25 shows the relationship between the range of total thicknesses of the two cadmium sulfide active layers, process efficiencies and the maximum percent of world cadmium sulfide production consumed in one year by this PV cel1. In the baseline copper indium selenide case, the thicknesses of the cadmium sulfide $P$ and $P^{+}$active layers were 1.7 and 0.8 microns, respectively. Information was not provided on the possible range of thicknesses for these two layers, so it was assumed that their total thicknesses could range from 1 to 5 microns. Two process efficiencies were assumed for this analys is, $35 \%$, the most likely evaporation efficiency, and 100\%, which assumes that a 11 of the cadmium sulfide lost in deposition could be recycled. At a process efficiency of $35 \%$, the total thickness of the two cadmium sulfide active layers would have to be reduced to about 1.5 microns before it would meet the $10 \%$ threshold level set for this criteria. However, if all of the cadmium sulfide used in the deposition process were recovered there would be no problem in meeting the $10 \%$ threshold level.

It is most likely technically impossible to reduce the total active layer thickness to less than 1.5 microns. Therefore, it is recommended that work be directed at recovering the cadmium sulfide lost during deposition.

"B" Material Discussions

The following "B" materials were reviewed and found not to constrain the deployment of the copper indium selenide cell. Generally, these materials are used in relatively small quantities and the cost to solar is small. Therefore, only severe future supply disruptions would significantly impact the copper indium selenide solar cell. The future availability and costs of these "B" materials should not present major obstacles in the large scale deployment of the copper indium selenide cell; however, these materials should be subject to periodic review. 


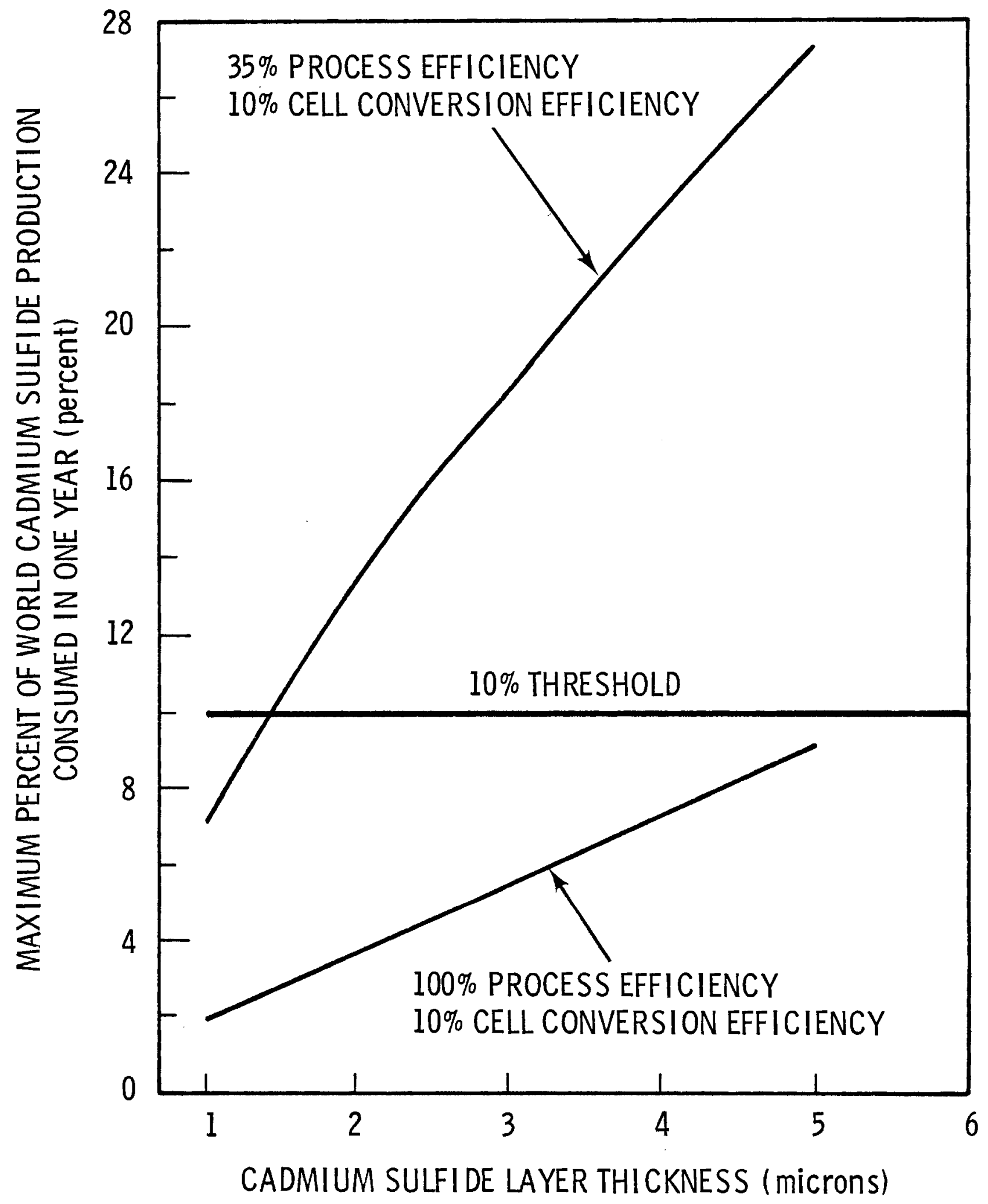

FIGURE 25. Total Cadmium Suifide Layer Thickness and Process Efficiency versus Maximum Percent of World Cadmium Sulfide Production Consumed in One Year 
Cadmium, hydrochloric acid, and petroleum coke are "B" materials since they are produced as byproducts. Ferromanganese, manganese ore, tin, tin ore, zinc, zinc ore, zinc byproducts, fluorspar, fluorspar ore, bauxite and chromite are "B" materials due to U.S. dependence on foreign sources for these materials (see Table 6), and U.S. reserves and resources of the ores are small.

Petroleum is classified as a "B" material since U.S. reserves are sma11. However, the future development of U.S. reserves, synfuels and imports should ensure adequate petroleum availability for photovoltaics.

Silicon SEG (20\% world production growth rate) and silicon monoxide (26\% of world production in one year) were identified as "B"; however, both materials are used in small quantities and their costs are well below the threshold levels. Since current production of these materials is small, a $20 \%$ production growth rate is relatively easy.

\section{CADMIUM SELENIDE PHOTOELECTROCHEMICAL SOLAR CELL}

\section{Cell Description}

The photoelectrochemical (PEC) cell uses an electrolyte to form a junction with an n-type semiconducting electrode. The counterelectrode of the cell is also in contact with the electrolyte. Several materials-related problems must be overcome during the development of this cell, the major one being instability of the semiconductor electrode in the electrolyte. Advantages of the PEC cell are possible high efficiencies, use of low cost materials and the capability of in-situ storage of electrical energy.

Because of the newness of this cell design, the optimum CdSe PEC solar cell structure has not as yet been determined. The schematic of the cell structure shown in Figure 26 represents present designs of front wall and backwa 11 CdSe PEC solar cells. These designs are subject to frequent changes. The 2 to $4 \mu \mathrm{m}$ thick CdSe active layer of the front wall cell is made by co-evaporating $\mathrm{Cd}$ and $\mathrm{Se}$ or by electrodeposition of $\mathrm{CdSO}_{4}$ and $\mathrm{SeO}_{2}$ onto a conducting substrate. The conducting substrate is usually $\mathrm{Ti}$ foil, .002 inches thick, but Ti $(1.0 \mu \mathrm{m})$ coated glass and ITO $(0.4$ to $0.4 \mu \mathrm{m})$ coated glass can also be used. Ti can either be sputtered or evaporated. ITO is sprayed using chemical 


\section{CdSe PEC SOLAR CELLS}

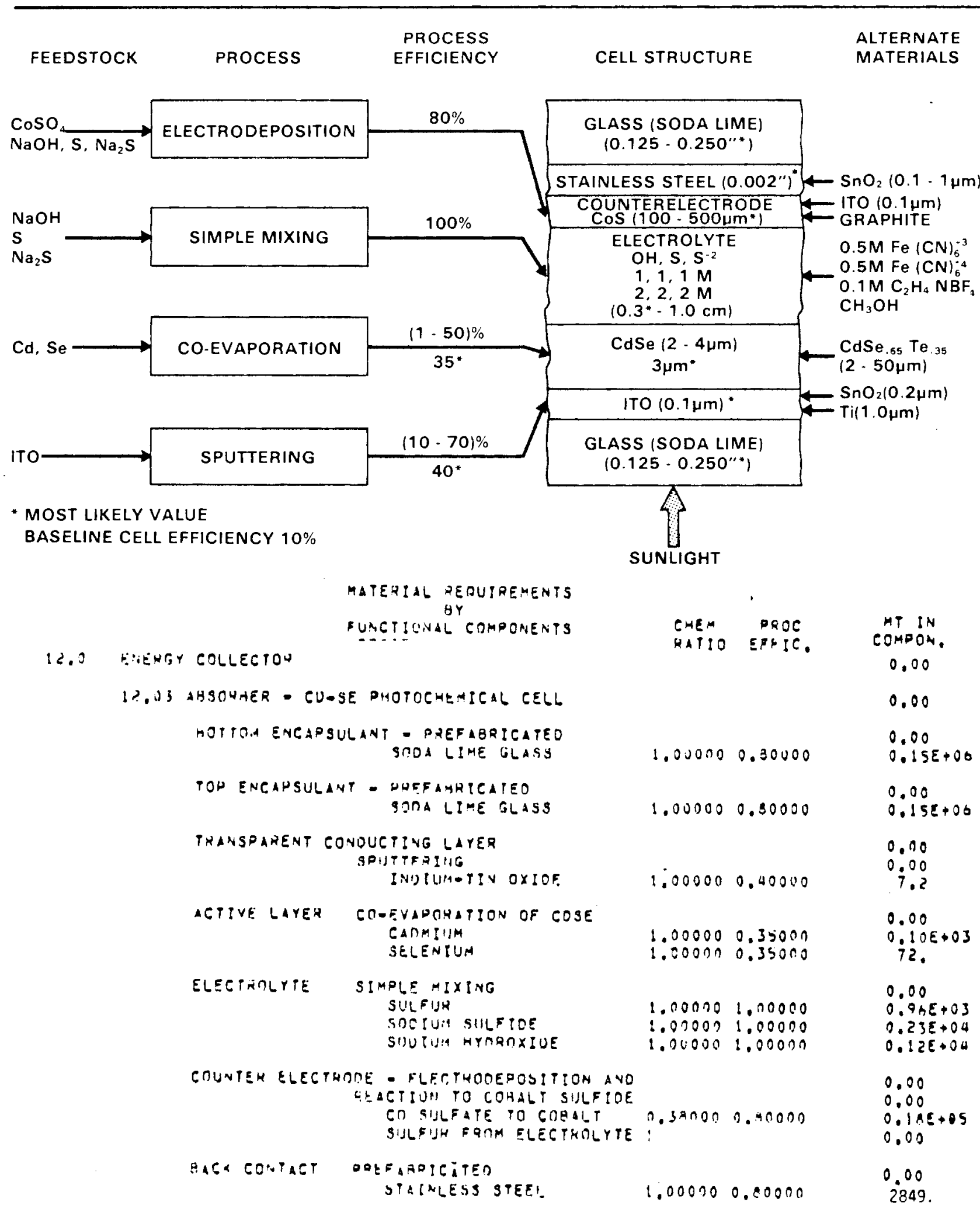

FIGURE 26. The Baseline Cadmium Selenide Photoelectrochemical Solar Cell 
solutions of $\mathrm{InCl}_{2}$ and $\mathrm{SnCl}_{4}$, sputtered using an ITO target or e-beam evaporated from an ITO source.

Several designs for placement of the counterelectrode in the electrolyte are being considered. The two most commonly used are: (1) placement of the counterelectrode under the active layer with electrolyte separating these layers, and (2) placement of a counterelectrode/wire mesh between the cell window and the cdSe active layer. The 100 to $500 \mathrm{\mu m}$ thick CoS counterelectrode is made by first electrodepositing cobalt from a cobalt sulfate solution. When contacted by the electrolyte, the cobalt reacts spontaneously with the sulfur to form CoS. Depending upon design, a stainless steel or Ti mesh may also be used to support the $\mathrm{CoS}$ counterelectrode. The electrolyte is a $1,1,1 \mathrm{M}$ or $2,2,2 \mathrm{M}$ polysulfate solution $\left(\mathrm{OH}^{-}, \mathrm{S}, \mathrm{S}^{-2}\right) 0.3$ to $1.0 \mathrm{~cm}$ in thickness, and is formed by simple mixing of $\mathrm{NaOH}$, elemental $\mathrm{S}$ and $\mathrm{Na}_{2} \mathrm{~S}$ in appropriate proportions. The $\mathrm{Na}$ cannot be eliminated from the solution.

There are several alternate materials used in this cell design.

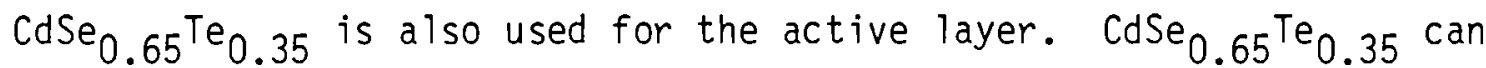
either be co-evaporated in thickness ranging from 2 to $4 \mu \mathrm{m}$ using $\mathrm{Cd}$, Se and $\mathrm{Te}$ sources or brushed onto the metal support substrate in thicknesses of $50 \mu \mathrm{m}$. The brush technique uses CdSe and CdTe in an organic binder and $\mathrm{CdCl}_{2} \mathrm{flux}_{\text {. }}$ The metal support substrate for the active layer can be replaced by $\mathrm{SnO}_{2}$ flux. The metal support substrate for the active layer can be replaced by $\mathrm{SnO}_{2}(0.1$ to $1 \mathrm{\mu m})$-coated glass. Alternate counterelectrodes are ITO $(0.1 \mathrm{\mu m})$ coated glass or porous graphite. A mixture of $0.5 \mathrm{M} \mathrm{Fe}(\mathrm{CN})_{6}^{-3}$, $0.5 \mathrm{M} \mathrm{Fe}(\mathrm{CN})_{6}{ }^{-4}, 0.1 \mathrm{M} \mathrm{C}_{2} \mathrm{H}_{4} \mathrm{NBF}_{4}$ and $\mathrm{CH}_{3} \mathrm{OH}$ can also serve as the electrolyte.

With the exception of the conducting support substrate, materials requirements for the backwall $\mathrm{CdSe}$ and $\mathrm{CdSe}_{0.65^{\mathrm{Te}}} \mathrm{T}_{0.35}$ cells are essentially the same as for front wall cells. The active layer of the backwall cell is cdSe or $\mathrm{CdSe}_{0.65^{T e_{0}}}{ }_{0.35}$ deposited onto an ITO-coated glass window layer. CdSe is usually co-evaporated in 2 to $4 \mu \mathrm{m}$ thicknesses from $\mathrm{Cd}$ and $\mathrm{Se}$ sources. $\mathrm{CdSe}_{0.65}{ }^{\mathrm{Te}} 0.35$ can either be co-evaporated from bulk $\mathrm{Cd}$, Se and $\mathrm{Te}$ or brushed using CdSe, CdTe and $\mathrm{CdCl}_{2}$ with thickness of 2 to $4 \mu \mathrm{m}$ and $50 \mu \mathrm{m}$, 
respectively. The active region is separated from the CoS counterelectrode by a 0.3 to $1.0 \mathrm{~cm}$ thickness of the previously mentioned electrolytes. Both front wall and backwall solar cells are encapsulated in either borosilicate or soda lime glass (0.125 to 0.250 inches).

Both front wall and backwall CdSe and $\mathrm{CdSe}_{0.65} \mathrm{Te}_{0.35}$ solar cells represented in Figure 26 , which illustrates materials requirements for these cells, including alternate materials. Representative deposition processes and their associated feedstock materials are shown in conjunction with the range of process efficiencies considered typical for each process. A $10 \%$ ce 11 conversion efficiency was assumed for the baseline cell. Layer thicknesses designated as "most likely" are representative of current CdSe and $\mathrm{CdSe}_{0.65}$ $\mathrm{Te}_{0.35} \mathrm{PEC}$ solar cells. The painting deposition process is discussed along with the screen printing process in a later section. All other processes have been discussed elsewhere (R. L. Watts et al., 1979).

Screening Results

Review of the CMAP screening of the baseline (Table 12) and sensitivity cadmium selenide photoelectrochemical solar cells identified the following "A" materials:

\begin{tabular}{ll}
\multicolumn{1}{c}{ Baseline } & Sensitivity Case 1: $7 \%$ cell conversion efficiency \\
$\begin{array}{ll}\text { Cobalt } & \text { Cobalt } \\
\text { Glass, Soda-lime } & \text { Glass, Soda-lime } \\
\text { Indium } & \text { Indium } \\
\text { Selenium } & \text { Selenium } \\
\text { Indium-tin oxide } & \text { Indium-tin oxide } \\
\text { Cobalt sulfate } & \text { Cobalt sulfate } \\
& \\
\text { Sensitivity Case 2: } & \text { substitute graphite counter electrode, cadmium- } \\
\text { selenide-telluride active layer, tin oxide transparent conducting layer, glass } \\
\text { ncapsulant .125 inches and 10\% cell conversion efficiency. }\end{array}$ \\
Glass, Soda-lime
\end{tabular}


TABLE 12. Bulk Material Requirements for: Cadmium Selenide Photoelectrochemical Solar Cell Baseline

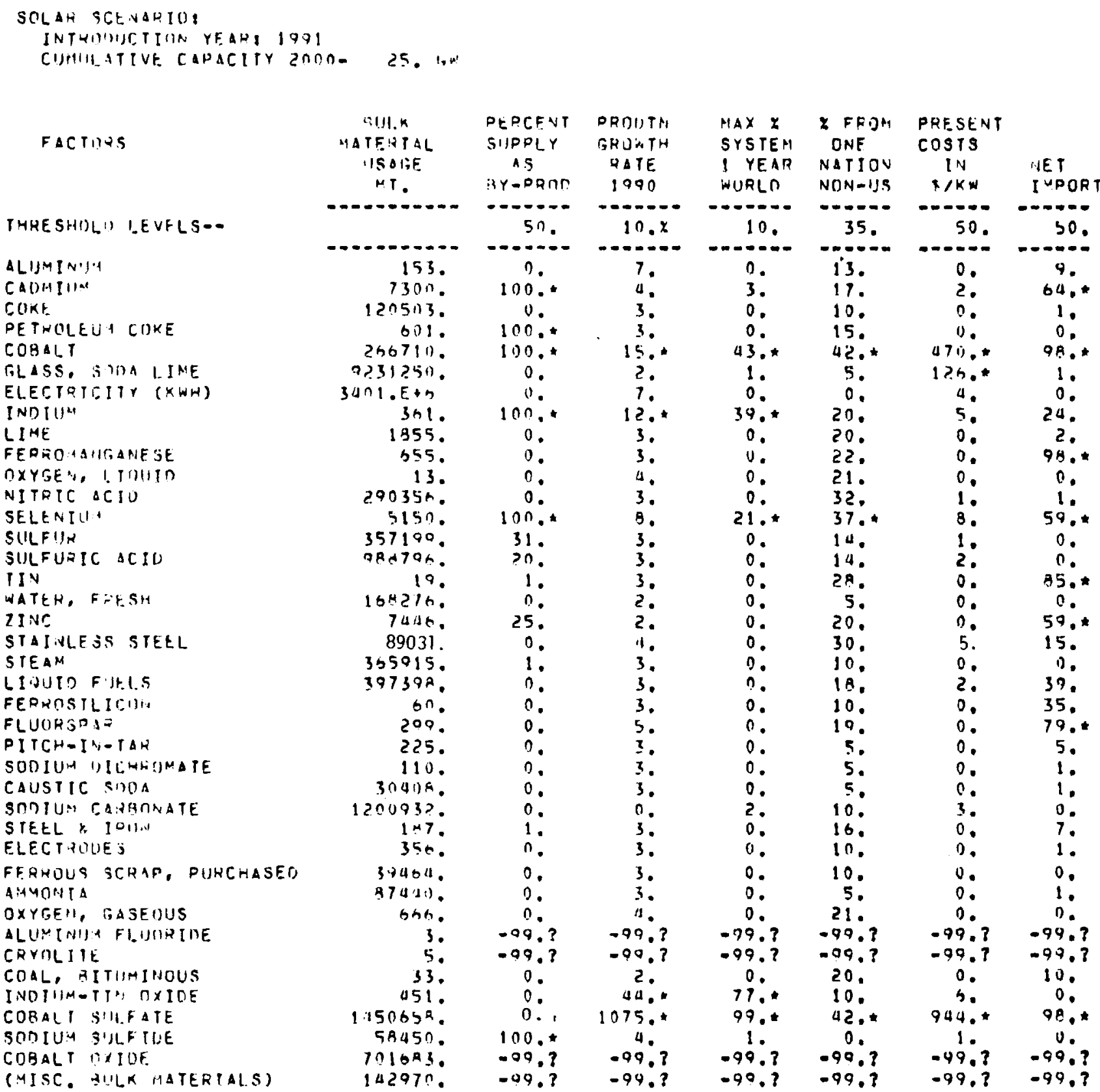


TABLE 12. (continued)

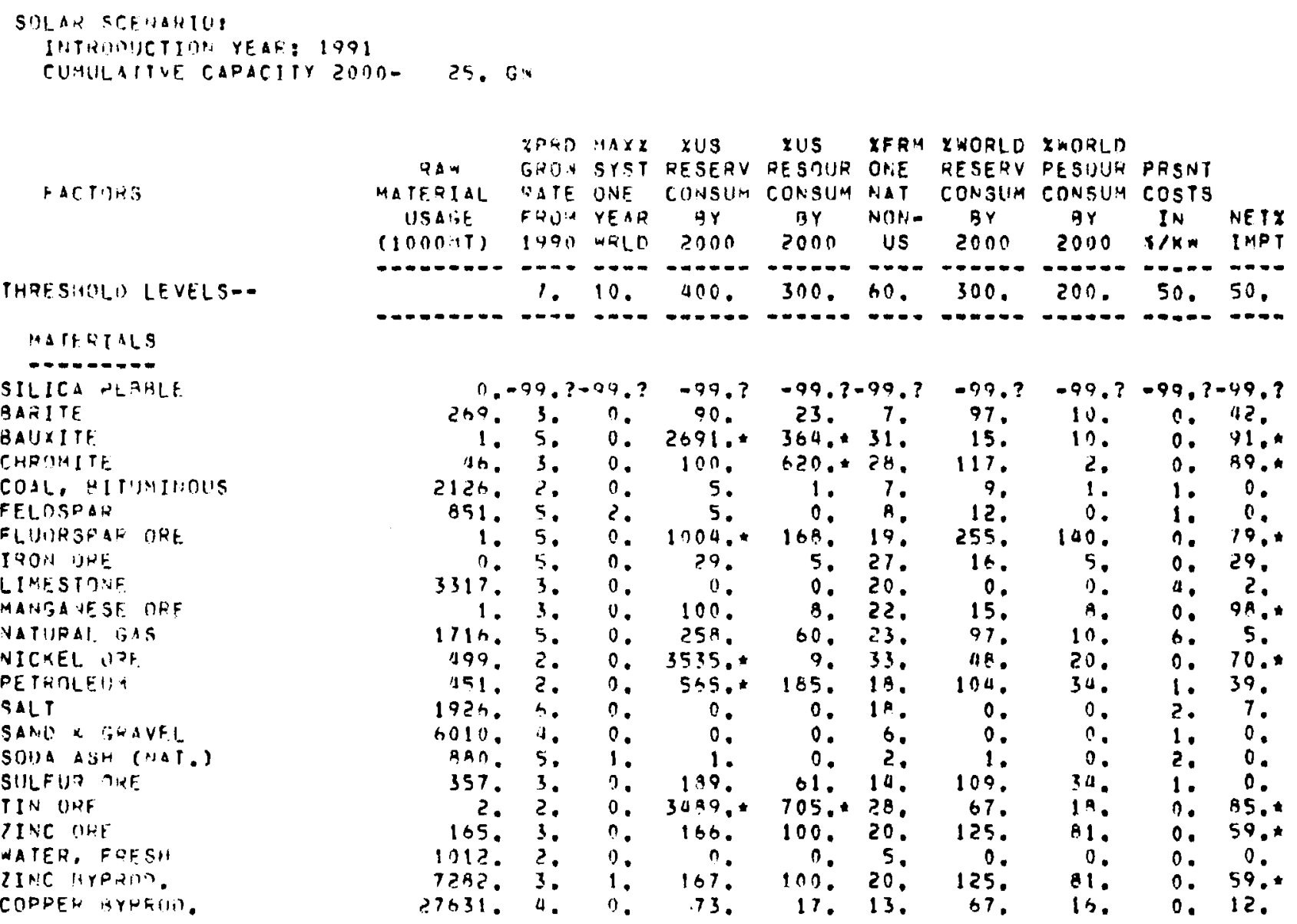


Tellurium

and the following "B" materials:

Baseline and Sensitivity Cases

$\begin{array}{ll}\text { Cadmium } & \text { Bauxite } \\ \text { Petroleum coke } & \text { Chromite } \\ \text { Ferromanganese } & \text { Fluorspar ore } \\ \text { Tin } & \text { Manganese ore } \\ \text { Zinc } & \text { Tin ore } \\ \text { Fluorspar } & \text { Zinc ore } \\ \text { Sodium sulfide } & \text { Zinc byproducts } \\ & \text { Nickel ore } \\ & \text { Petroleum }\end{array}$

"A" Material Discussions

Cobalt and Cobalt Sulfate may present both availability and cost constraints if the cadmium selenide photoelectrochemical cell is deployed on a large scale. Cobalt usage in this cell (266710 MT) would require a 15\% production growth rate between 1990 and 1991, would consume 43\% of world cobalt production in one year at a cost of $\$ .47 /$ watt. Cobalt sulfate usage (1450 658 MT) would require a 1075\% production growth rate between 1990 and 2000 , would consume $99 \%$ of world cobalt sulfate production in one year, and would cost $\$ .94 /$ watt. In sensitivity case 1 (7\% cell conversion efficiency), the cobalt and cobalt sulfate availability and cost problems were even more severe.

Figure 27 shows the relationship between the present cost of cobalt and the thickness of the cobalt sulfide counter electrode. Two separate cases are shown; in one case the electrodeposition process efficiency is $80 \%$ and in the second case, the process efficiency is assumed to be $100 \%$ (i.e., a 11 of the cobalt lost during electrodeposition is recycled). In both cases the cell conversion efficiency is assumed to be $10 \%$. From this figure, it is apparent that cobalt will provide a cost constraint to the large scale deployment of the cadmium selenide photoelectrochemical cell even at 100 microns and assuming $100 \%$ recycling of the cobalt. 


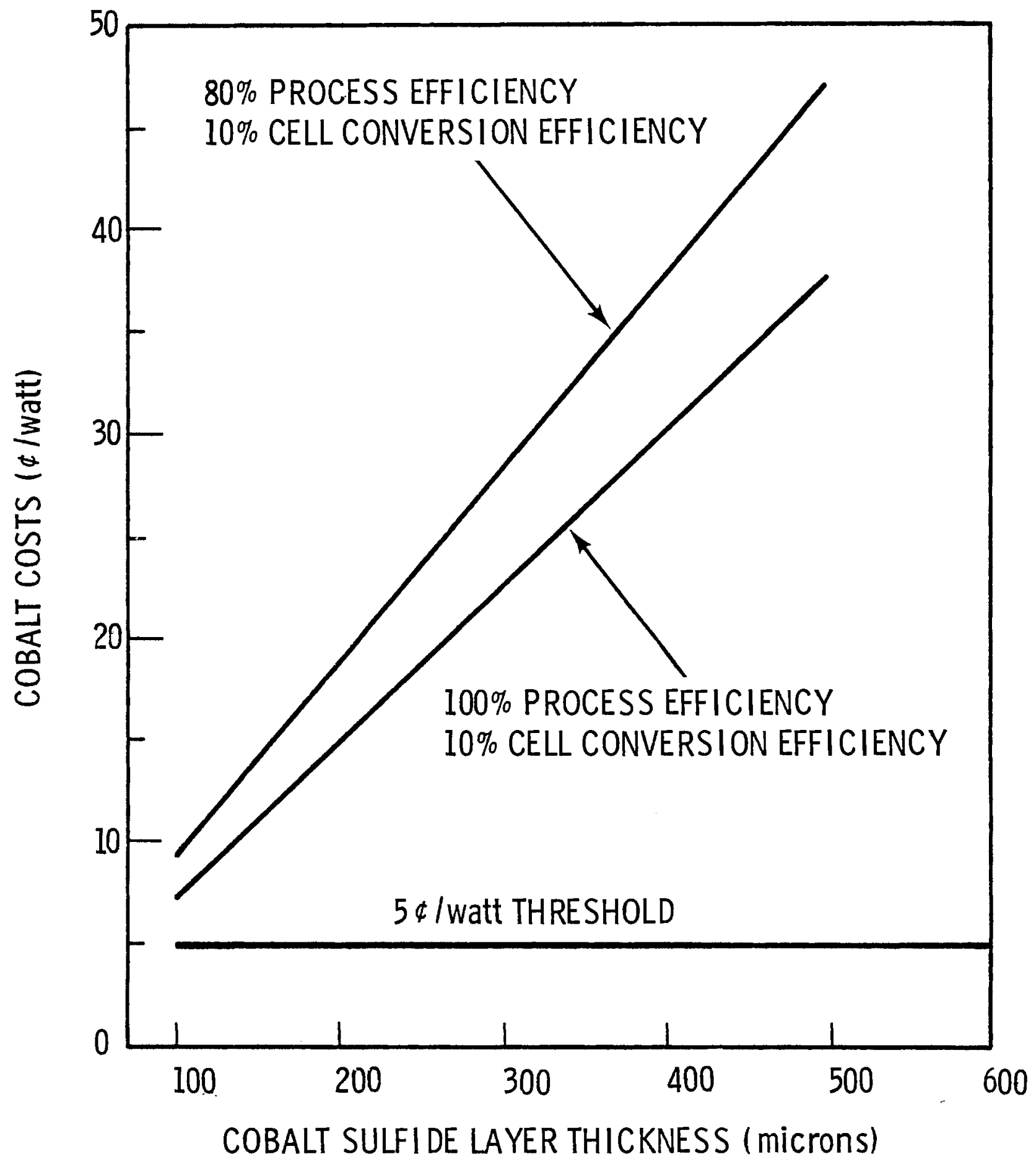

FIGURE 27. Cobalt Present Cost versus the Thickness of the Colbalt Sulfide Counter Electrode 
Current domestic production of cobalt sulfate is about 860 MT/year most of which is used as an animal feed supplement and in water treatment. A major U.S. cobalt sulfate manufacturer states that production could be doubled if a profitable future market were to develop and if sufficient quantities of cobalt were available to produce it.

Domestic mine production of cobalt ceased in 1971, and only one U.S. company currently produces extra fine cobalt for cutting tools. In 1979, the U.S. imported $98 \%$ of the cobalt consumed in the U.S. from Zaire. With the political unrest in many of the African countries, the U.S. cannot be assured of adequate cobalt supplies from this source in the future. However, another future source of cobalt to be developed in the next few years is manganese deep sea nodules. These nodules conta in four major metals: nickel, copper, manganese and cobalt. This source would significantly lessen the future uncertainty as to the availability of cobalt. Initial research on these nodules estimates their cobalt content at $2.5 \times 10^{9}$ MT. All of the economic and technical factors involved in the recovery of the nodules and the ir contained metals have been solved. However, several institutional factors still remain. It is expected that these issues should be resolved within the next few years and that comercial mining will begin in the early 1980s.

If institutional and legal issues delay the mining and processing of the deep sea nodules, an alternative is to have the cell fabricators enter into long term contracts with the cobalt sulfate producers. These contracts would, in turn, encourage the cobalt sulfate producers to enter into contracts with cobalt producing nations such as Zaire. During 1978 the supply of cobalt to the U.S. was severely reduced and many producers of cobalt products were forced to fill only a portion of their customer's orders. However, one large U.S. cobalt sulfate producer had entered into long term contracts with Zaire and Finland and was able to fill 100\% of their customer's orders.

In the second sensitivity case, graphite ${ }^{(a)}$ was substituted for the cobalt in the counter electrode. Analys is of the CMAP screening results

(a) The graphite screening data is based on all manufactured graphite. Price data is estimated for substrate grade manufactured graphite. 
indicate that there should be no availability constraints associated with the use of graphite in the counter electrode. However, research should be directed towards estimating the purity and cost of graphite for this cell.

Indium-tin Oxide (ITO) is used in the transparent conducting layer of the cadmium selenide photoelectrochemical ce11. This cell would require 451/MT of ITO between 1991 and 2000 and would consume $77 \%$ of the world's ITO production in one year, if efficiency were increased to $100 \%, 180$ MT of ITO would be required between 1991 and 2000, and would consume $42 \%$ of world IT0 production in one year. To make 451 MT of ITO would require 361 MT of indium between 1991 and 2000 and $12 \%$ indium production growth rate between 1990 and 1991 . At current prices, ITO and indium should not present major cost constraints to this cell.

The thickness of the ITO transparent conducting layer is 0.1 microns. It is unlikely that the thickness of this layer could be reduced sufficiently to avert potential availability problems. Increasing the sputtering process efficiency from $40 \%$ to $100 \%$ would reduce the IT0 requirements to 180 MT between 1991 and 2000 and this cell would consume $42 \%$ of the world's ITO production in one year. However, in sensitivity Case 2, tin oxide was substituted for the ITO and no availability or cost constraints were identified.

Glass, soda-lime is used as a top and bottom encapsulant in the cadmium selenide photoelectrochemical cel1. The baseline characterization of this cell would require 9,231,250 MT of soda lime glass between 1991 and 2000 at a cost to photovoltaics of $\$ .13 /$ watt. The assumed thickness for each glass layer in the baseline case was .25 inches (or a total of .5 incies for both glass layer).

In sensitivity Case 2, the thickness of each glass encapsulant layer was reduced to .125 inches (or a total of .25 inches for both layers). At $\$ .06 /$ watt soda lime glass would still present cost constraint to the large scale deployment of the cadmium selenide photoelectrochemical cell.

The relationship between total encapsulant layer thickness and the present cost of soda lime glass in cent/watt is presented in Figure 28 . The $\$ .05 /$ watt reference line represents the threshold level set for this screening criteria 


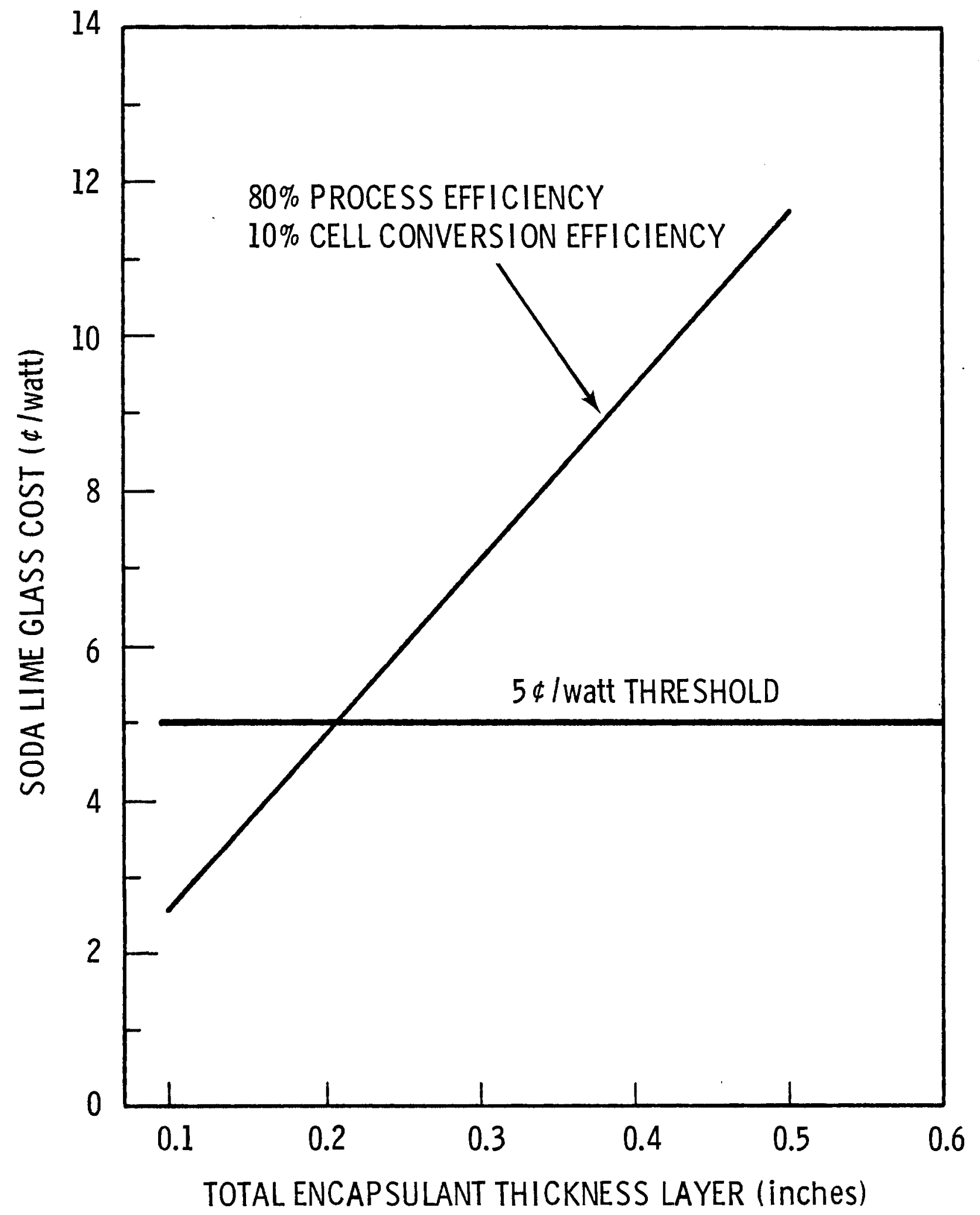

FIGURE 28. Total Encapsulant Layer Thickness and Soda Lime Glass Present Costs 
in CMAP. In order for the present costs of the soda lime glass to fall below th is threshold level, the total thickness of the two glass encapsulant layers would have to be reduced to .2 inches, or .1 inches per layer. Therefore, we recommend that work be directed towards reducing the total thickness of these two layers to less than .2 inches. If this proves to be technically infeasible an alternative would be to enter into long term contracts with soda lime glass manufacturers. These contracts would assure glass producer's of a viable future photovoltaic's market. These contracts may encourage glass manufacturers to grant price discounts (beyond normal quantity discounts) to cell fabricators.

Selenium is classified as an "A" material in the baseline cadmium selenide PEC cell. The cell would require a cumulative 5150 MT, and in the year 2000 i.t would require 930 MT or $21 \%$ of the world selenium production. If the cell efficiency were decreased from $10 \%$ to $7 \%$ (a sensitivity case), the cell requirement is increased to 7360 MT and $28 \%$ of world production. Clearly, these levels of selenium use in photovoltaic cells will require advance planning to assure adequate availability and reasonable material cost. A rapid increase in PV cell demand could lead to precipitous price rise. At current prices, the selenium cost is only $\$ .008$ per watt for the $10 \%$ efficiency baseline cell which has a 3 micron layer of CdSe vapor deposited at $35 \%$ efficiency. If the brush technique is substituted for vapor deposition, the layer thickness and process efficiency increase to 50 microns and $80 \%$, respectively. One year selenium use increases to $66 \%$ of world consumption, selenium production must grow at a maximum rate of $22 \%$ per year, and the selenium cost becomes $\$ .06$ per watt which is a significant fraction of the DOE module cost goals of $\$ .15$ to $\$ .40 /$ watt.

A perspective of the selenium supply problems for the CdSe PEC cell can be gained from Figures 29 and 30 . Selenium consumption in CdSe layers is plotted as a function of process (evaporation and brush technique), probable range of process efficiencies and probable cdSe layer thicknesses. Two obvious conclusions can be drawn from Figures 29 and 30: 1) in all probable thicknesses and process efficiencies the brush technique imposes severe supply problems compared to the evaporation technique, and 2) with the evaporation process and 


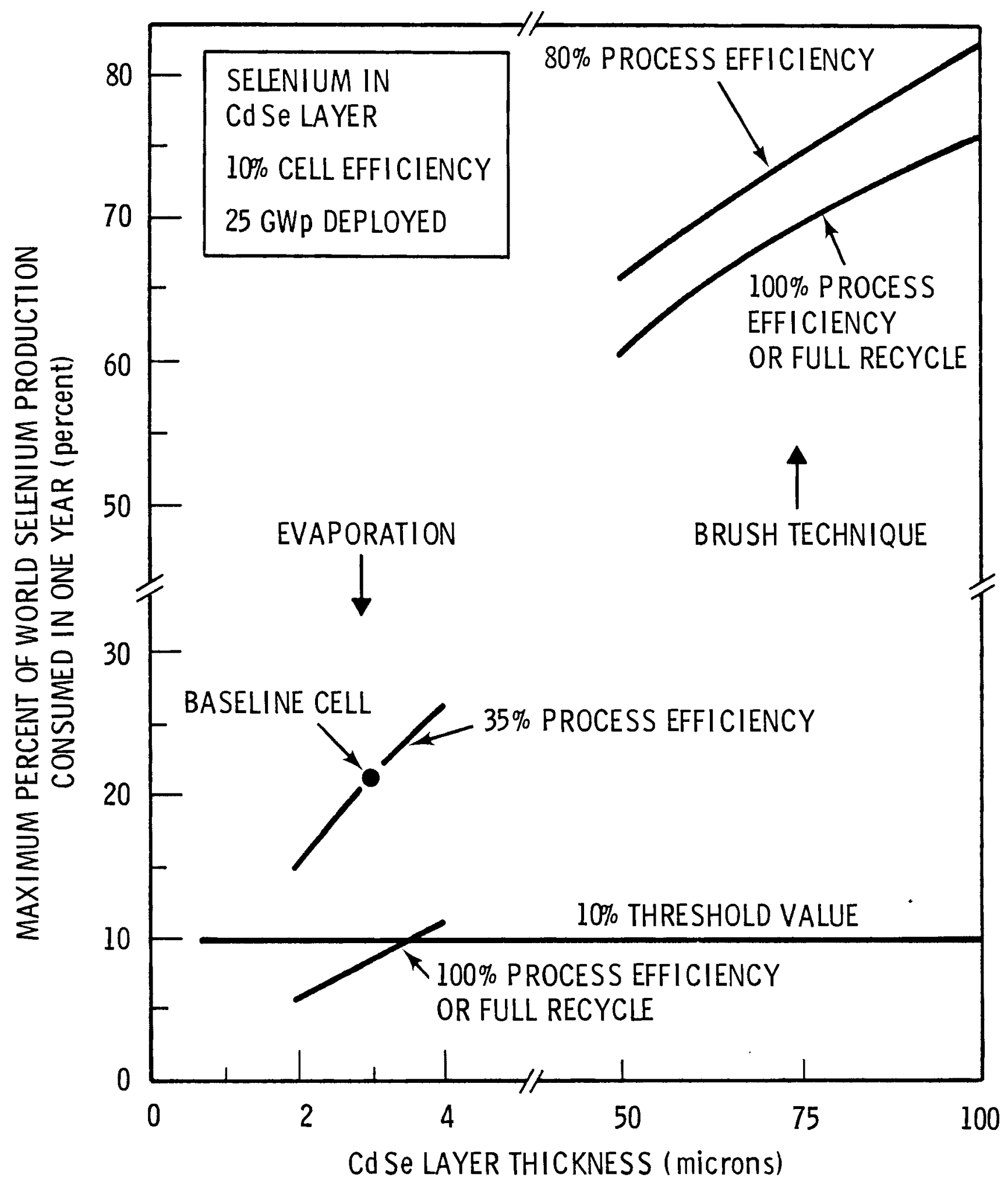

FIGURE 29. Selenium Requirement as a Function of Process, Process Efficiency (a), and CdSe Layer Thickness 


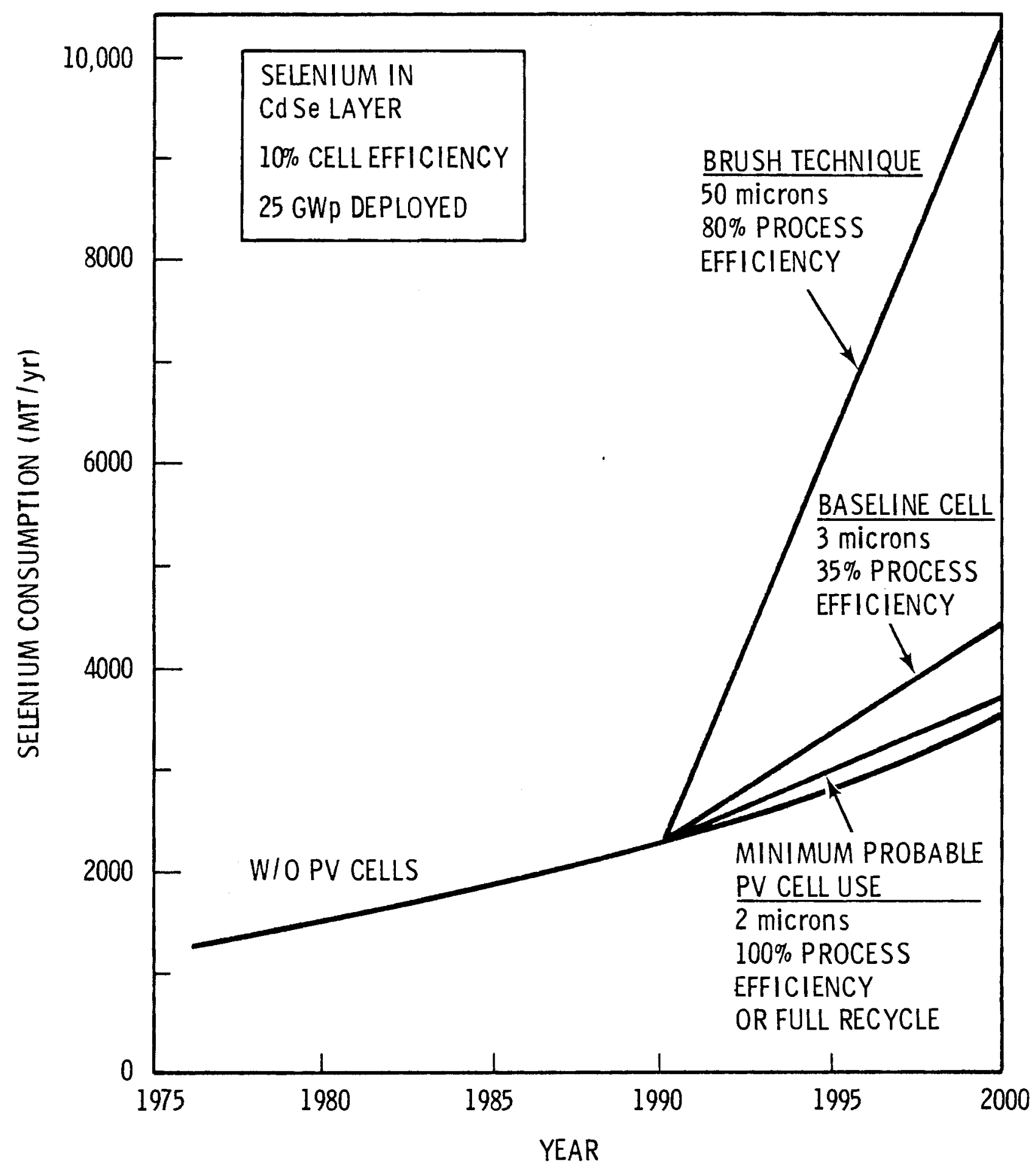

FIGURE 30. Projected Market for Selenium as a Function of Process, Process Efficiency and CdSe Layer Thickness 
full recycle of wasted selenium not deposited usefully on the cell layer, the selenium supply problem essentially vanishes.

Use of the evaporation process and full recycle of wasted selenium appear to be most attractive for CaSe layers; if not, then selenium supply problems would be incurred. The supply of selenium and recomendations for ameliarating selenium supply problems are discussed in the section covering copper indium selenide cells and will not be repeated here.

When $\mathrm{CdSe}_{0.65^{T e_{0}}} 0.35$ is substituted for CdSe (the final sensitivity case), the selenium usage and attendant supply problems remain the same, albeit reduced in magnitude, as illustrated in Figures 31 and 32 which are parallel to Figures 29 and 30 respectively. However, tellurium supply for $\mathrm{CdSe}_{0.65}$ Te 0.35 layers is more problematical.

Tellurium is an " $A$ " material since a total of 2735 MT and a maximum one year share of $59 \%$ of world consumption of tellurium would be required to deploy $25 \mathrm{GW}_{\mathrm{p}}$ of PEC cells with a 3 micron thick $\mathrm{CdSe}_{0.65} \mathrm{Te}_{0.35}$ layer. Also a maximum yearly worldwide tellurium production growth rate of $17 \%$ would be needed. If such a deployment scenario is to be met, some advance planning will be required to assure adequate tellurium supplies. Like selenium, tellurium is a byproduct of copper refining. Sharp price increases could result from sudden, unplanned, increases in PV cell use. At current prices, selenium and tellurium each cost only $\$ .005 /$ watt for the $10 \%$ efficient baseline cell with 3 micron $\mathrm{CdSe}_{0.65} \mathrm{Te}_{0.35}$ layer deposited at $35 \%$ efficiency. If the brush technique were substituted for evaporation the most likely layer thickness and process efficiency increase to 50 microns and $80 \%$, respectively. One year tellurium and selenium uses increase to $91 \%$ and $54 \%$, respectively of wor $1 d$ consumption. The combined cost of selenium and tellurium becomes $\$ .07 /$ watt (about 3.5 cents each), a significant portion of the DOE cost goals of 15 to 40 cents per watt.

Figures 33 and 34 illustrate the relationships between tellurium consumption, process, process efficiency, and $\mathrm{CdSe}_{0.65} \mathrm{Te}_{0.35}$ layer thickness. Again, it is immediately clear that the brush technique would introduce severe supply problems for tellurium; production rates would have to be increased over 


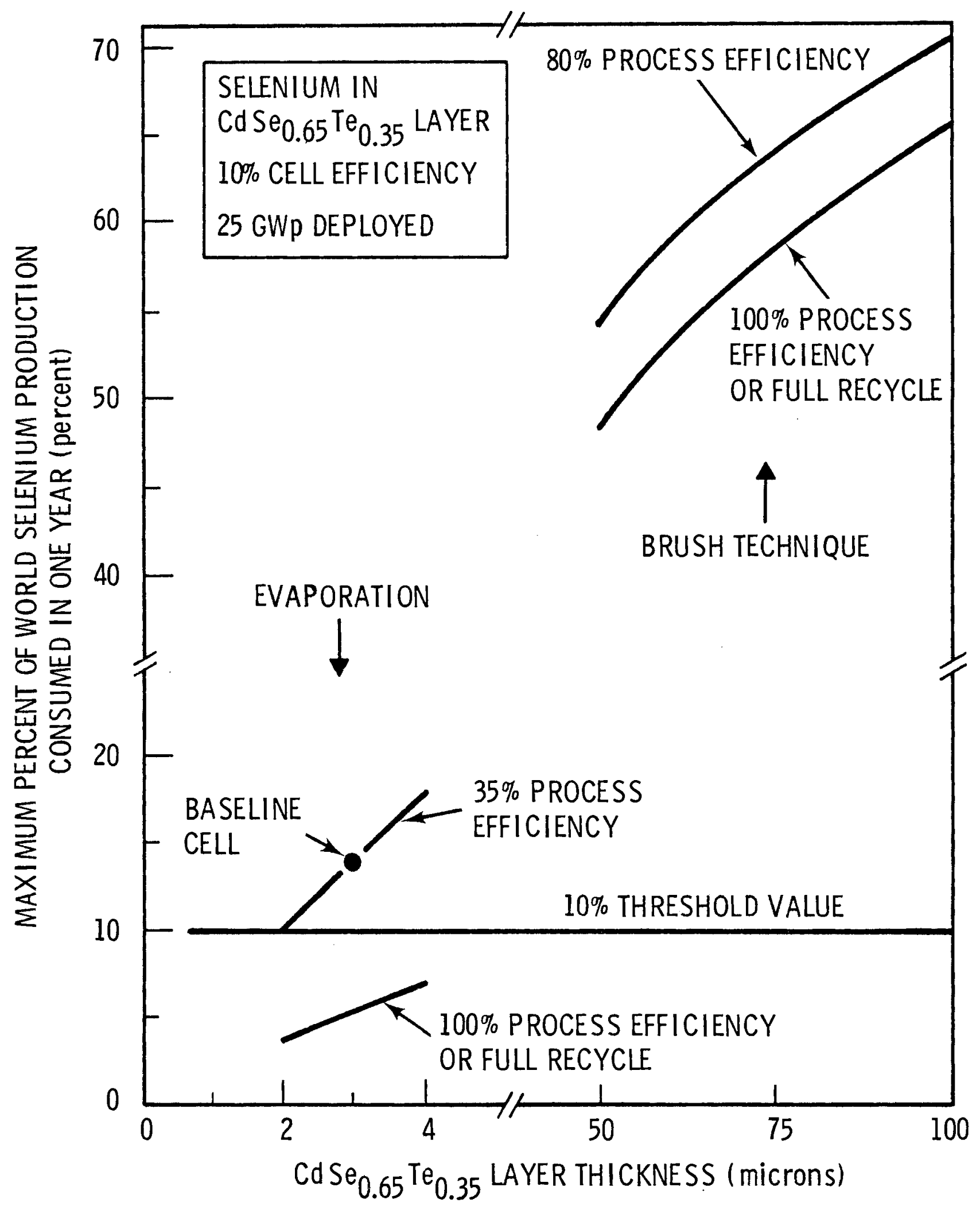

FIGURE 31. Selenium Requirement as a Function of Process, Process Efficiency $(\mathrm{e})$, and $\mathrm{CdSe}_{0.65^{T e_{0}}} 0.35$ Layer Thickness 


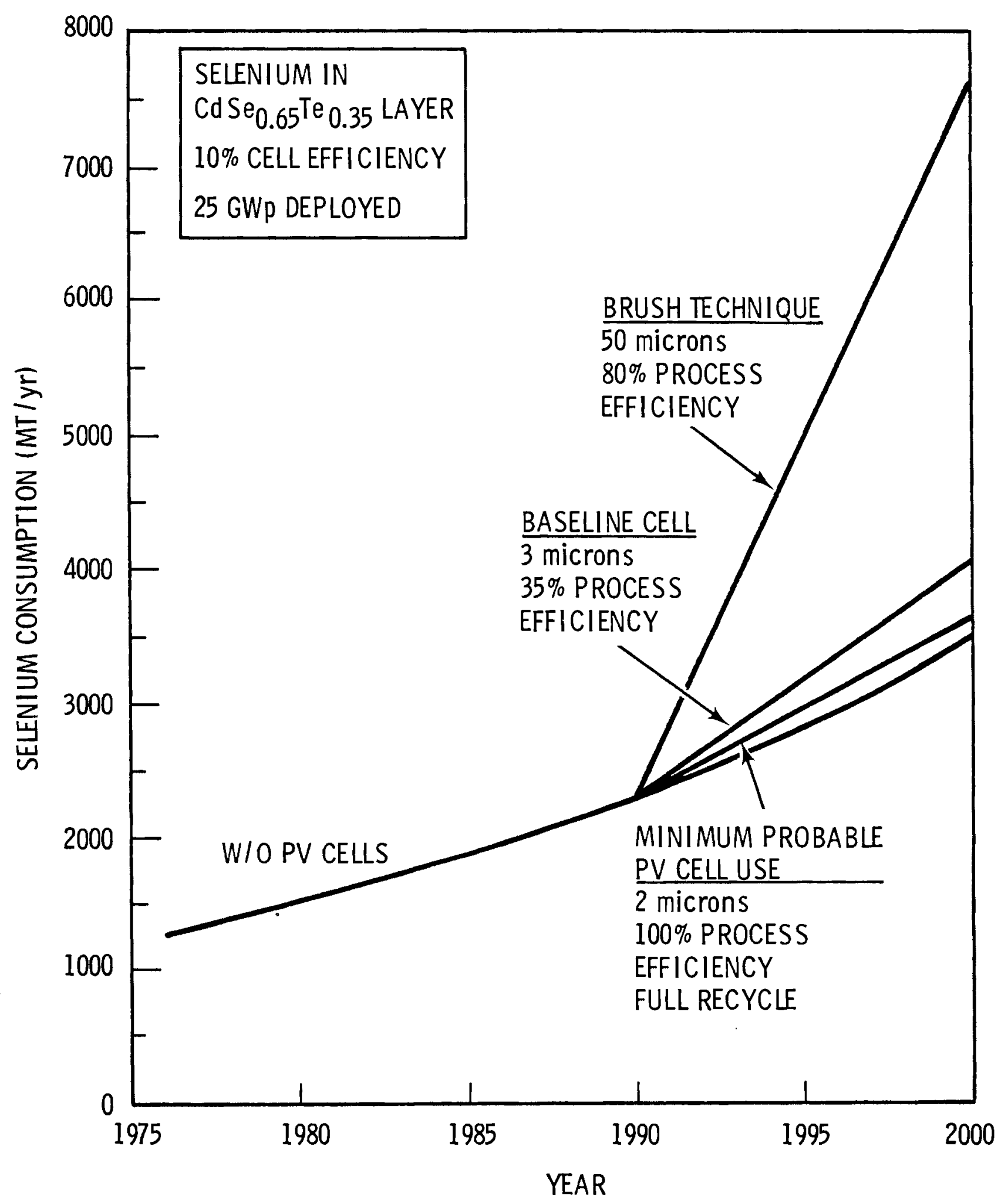

FIGURE 32. Projected Market for Selenium as a Function of Process, Process Efficiency ${ }^{(e)}$, and CdSe $0.65^{T e_{0}} 0.35$ Layer Thickness 


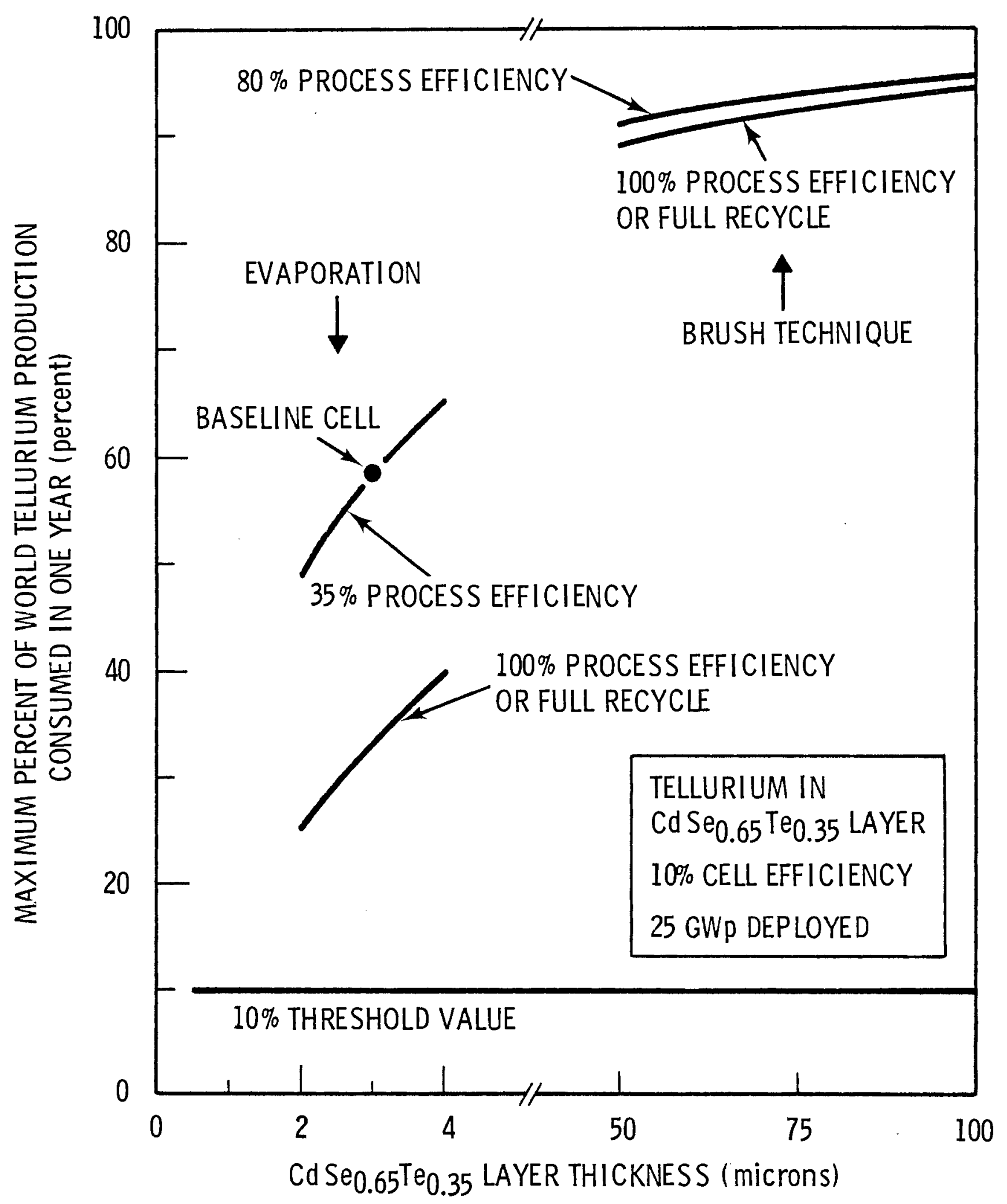

FIGURE 33. Tellurium Requirement as a Function of Process, Process Efficiency $(\mathrm{e})$, and $\mathrm{CdSe}_{0.65} \mathrm{Te}_{0.35}$ Layer Thickness 


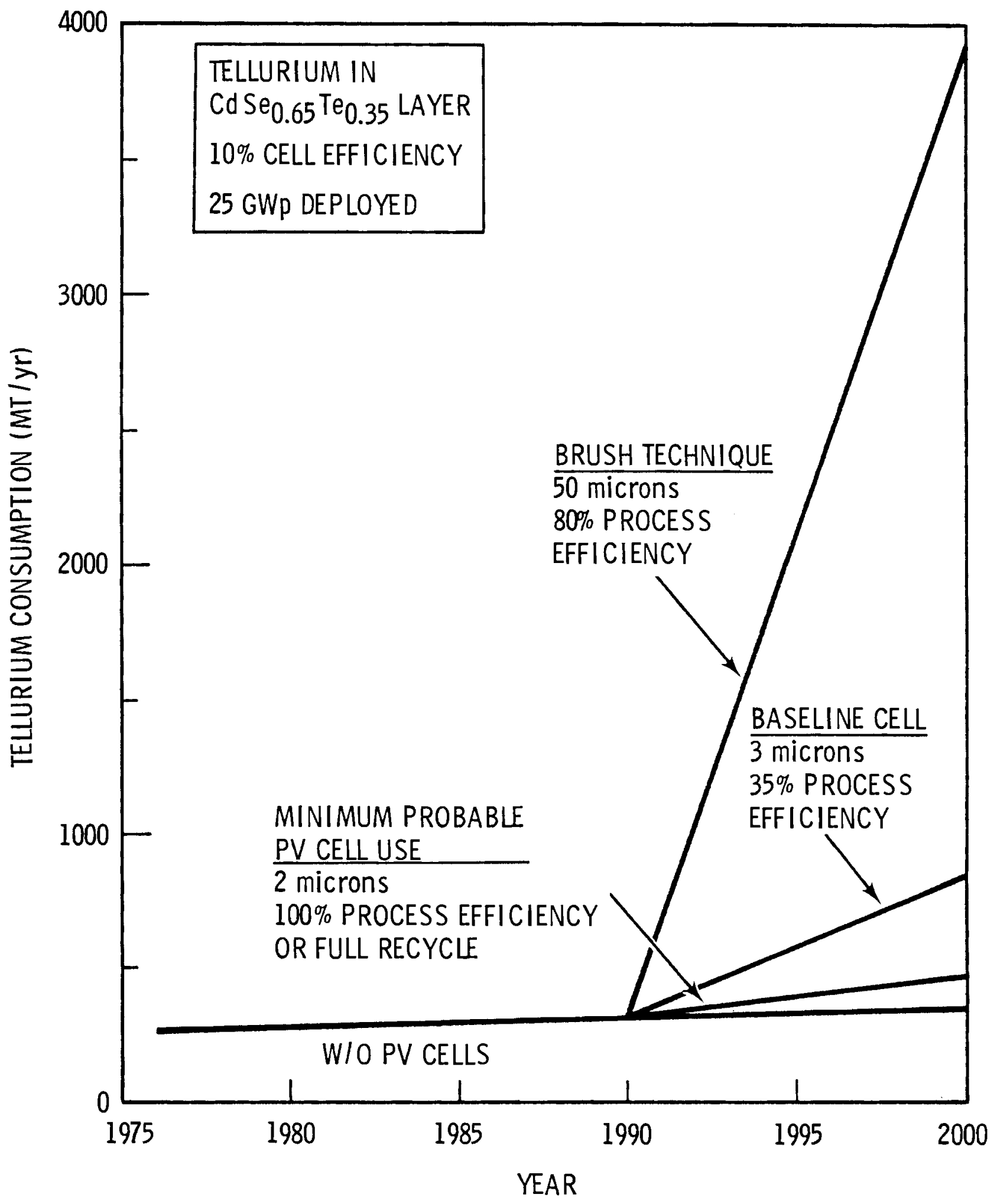

FIGURE 34. Projected Market for Tellerium as a Function of Process, Process Efficiency (e), and $\mathrm{CdSe}_{0.65} \mathrm{Te}_{0.35}$ Layer Thickness 
10 times (see Figure 34) in order to meet tellurium demand for PV cells in the year 2000. It is unlikely that such a demand could be met without significant price increases which would push the selenium cost of 3.5 cents/watt to an untenable level. Therefore, the evaporation process should be favored over the brush technique from the perspective of material supply and cost.

Tellurium consumption would be minimized in the evaporation process by recycling all material not deposited usefully on the cell. With recycle, tellurium requirements are reduced to 960 MT total and about 173 MT or $33 \%$ of world comsumption in the year 2000 . Thus, even with $100 \%$ recycling, significant tellurium supply problems could result. It would seem preferable to minimize supply problems by using the tellurium free cdSe layer in this cell. If not, tellurium supply problems will have to be addressed at an early date to assure adequate supply. A discussion of tellurium availability is contained in the section concerning cadmium telluride cells and will not be repeated here.

In view of the many options available with the photoelectrochemical cell, the following recommendations are made:

- Minimize the CdSe layer thickness, thus favoring processes such as evaporation over the brush technique.

- Recycle all Se (and Cd) waste from cell fabrication.

- Lacking recycle, increase the deposition process efficiency.

- Favor CdSe layers over $\mathrm{CdSe}_{0.65} \mathrm{Te}_{0.35}$ layers.

- If $\mathrm{CdSe}_{0}{ }_{65}{ }^{\mathrm{Te}} \mathrm{e}_{35}$ is the preferred layer, tellurium supplies should be addressed. Actions might include comnunicating PV needs to tellurium suppliers years in advance, executing long term supply agreements, stockpiling tellurium, and improving the recovery of tellurium from anode slimes without incurring significant cost increases.

"B" Materials Discussions

The following "B" materials were reviewed and found not to constrain the deployment of the cadmium selenide photoelectrochemical solar cell. Generally, these materials are used in relatively small quantities and the cost to solar is low. Therefore, only severe future supply disruptions would significantly impact the cadmium selenide photoelectrochemical cell. The future availability 
and costs of these "B" materials should not present major obstacles to the rarge scale deployment of the cadmium selenide photoe?ectrochemical cells; however, these materials should be subject to periodic review.

Ferromanganese, manganese ore, tin, tin ore, zinc, zinc ore, fluorspar, fluorspar ore, bauxite, chromite and nickel ore are classified as "B" materials because of the U.S.'s dependence on foreign sources (ranging from $59 \%$ to 98\%, see Table 6). However, severe future supply disruptions are not anticipated for any of these materials, and therefore should not present major availability or cost problems in the future.

Cadmium, sodium sulfide, and petroleum coke are "B" materials since they are produced as byproducts of zinc, barium carbonate and petroleum respectively.

Petroleum is a "B" material since U.S. reserves are small. Imports, synfuel production and reserves to be developed should assure availability of petroleum for the very small solar requirements. 
THE POTENTIAL MATERIAL CONSTRAINTS FOR FIVE CELLS ANALYZED TOGETHER

There are interesting effects resulting from $25 \mathrm{GW}$ of $\mathrm{PV}$ on line by the year 2000 made up of a variety of cells. In this study the $25 \mathrm{GW}$ is composed of $5 \mathrm{GW}$ each of the five baseline cells being studied in this report. As we would expect, the pressure on specific materials markets would be significantly reduced as can be seen in the results (see Tables 13 through 16).

It could be argued that the market would more likely be made up using several cell designs rather than a single one since they will not be strictly identical in performance characteristics, etc. Spectral response characteristics of cells are different, application needs will vary, and solar insolation characteristics are site-specific. These are some of the factors arguing for plurality of approach. In any case, it was decided to balance off the analysis of cells individually with an analysis of five cells together making up $25 \mathrm{GW}$.

CMAP was designed with this problem in mind and it can accumulate the materials requirements from several PV cells; screen this accumulation using the stored data just as if it were analyzing an individual cell. One difficulty encountered with this process is that the $\$ / \mathrm{kW}$ computed is an average over all of the cells (25 GW each of 5 cells in this case). Normally the $\$ / \mathrm{kW}$ would be interpreted as a measure of the importance of the material in a specific cell. In the summary analysis, that is not what is being given. Rather, it is a measure of an "average importance". Fortunately, the importance to the single cell can be obtained by referring to the base cases for the individual cells (the $\$ / \mathrm{kW}$ is independent of the amount of $\mathrm{GW}$ installed).

\section{Discussion of the Screening Results of Mixed Scenario}

Cobalt and cobalt sulfate will still present availability and cost constraints to the deployment of photovoltaics. The development of the deep sea nodules may ease these problems. An alternative is to substitute graphite in the counterelectrode of the cadmium selenide photoelectrochemical cell.

Indium and indium-tin oxide are still "A" materials since their supply capacity will be receiving pressure. The recommended strategies are to reduce 
TABLE 13. Bulk Material Summary Report

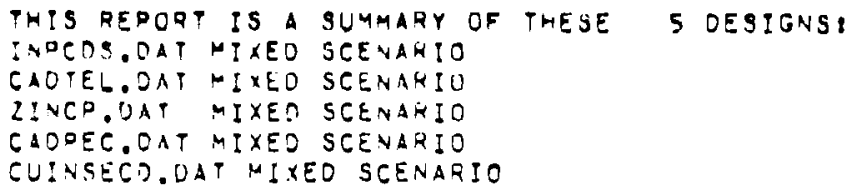

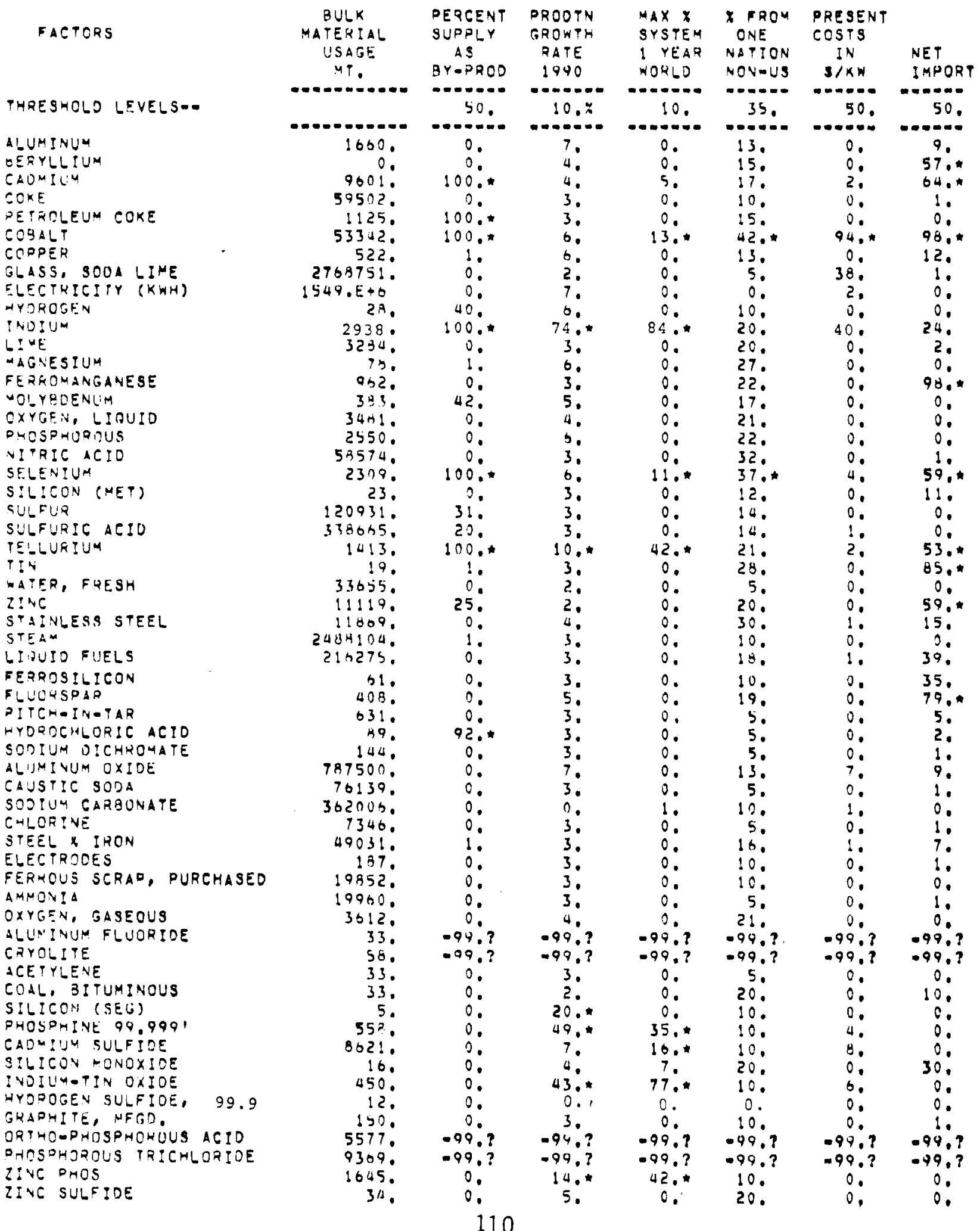


TABLE 13. (continued)

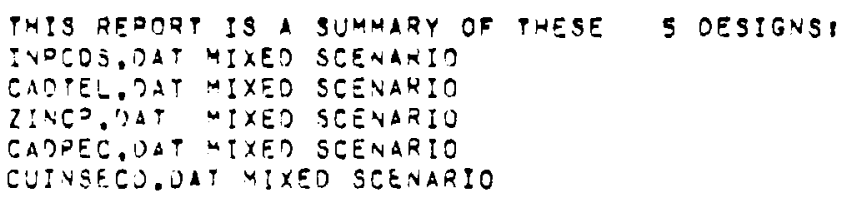

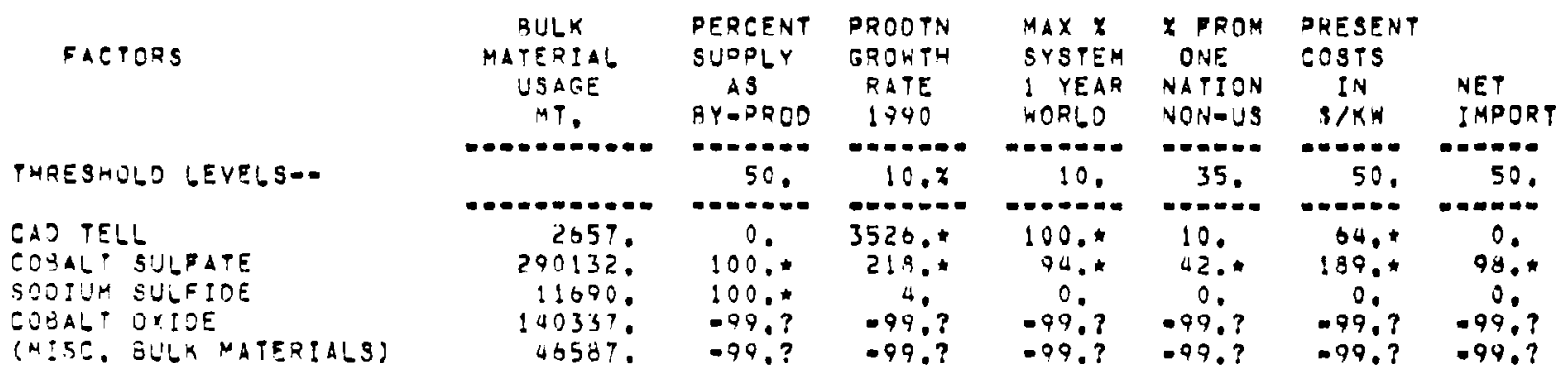


TABLE 14. "A" Materials (Baseline Cases)

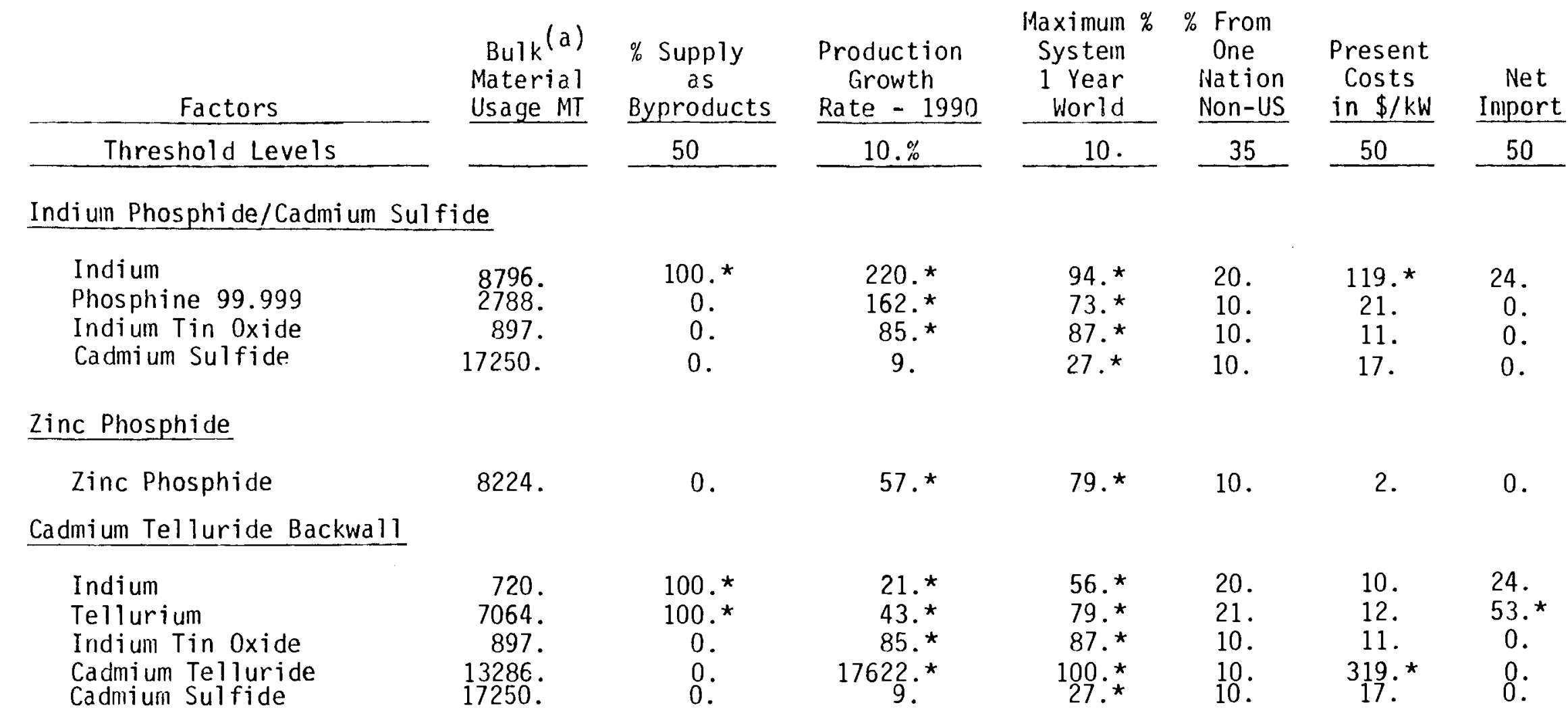

(a) Material required to produce $25 \mathrm{GW}(p)$. 
TABLE 14. "A" Materials (Baseline Cases)

\begin{tabular}{|c|c|c|c|c|c|c|c|}
\hline Factors & $\begin{array}{l}\text { Bulk(a) } \\
\text { Material } \\
\text { Usage MT } \\
\end{array}$ & $\begin{array}{c}\% \text { Supply } \\
\text { as } \\
\text { Byproducts }\end{array}$ & $\begin{array}{c}\text { Production } \\
\text { Growth } \\
\text { Rate - } 1990 \\
\end{array}$ & $\begin{array}{c}\text { Maximum } \% \\
\text { System } \\
1 \text { Year } \\
\text { World } \\
\end{array}$ & $\begin{array}{l}\% \text { From } \\
\text { One } \\
\text { ivation } \\
\text { Non-US } \\
\end{array}$ & $\begin{array}{c}\text { Present } \\
\text { Costs } \\
\text { in } \$ / \mathrm{kW} \\
\end{array}$ & $\begin{array}{c}\text { Net } \\
\text { Inıport }\end{array}$ \\
\hline Threshold Levels & & 50 & $10 \%$ & 10 & 35 & 50 & 50 \\
\hline
\end{tabular}

Copper-Indium Selenide/Cadmium Sulfide

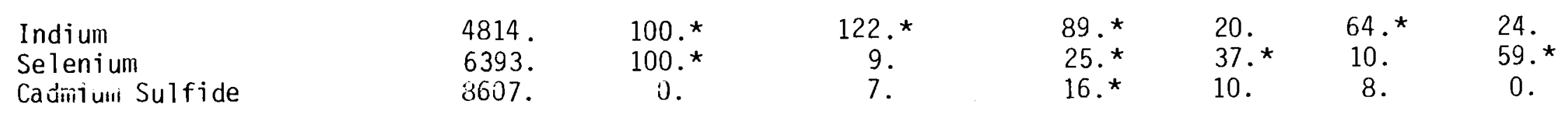

Cadmium Selenide Photoelectrochenical

Cobalt

Glass, Soda Lime

Indium

Selenium

Indium Tin Oxide

Cobalt Sulfate

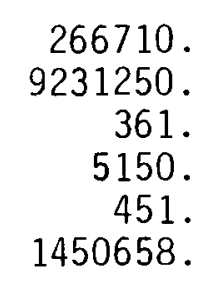

$15 . \star$
2.
12.
8.
$44 . \star$
$1075 . \star$

1075.*

$43 . *$
1.
$39 . *$
$21 . *$
77. *
99. *

$$
\text { 42.* }
$$$$
5 .
$$$$
20 \text {. }
$$$$
37
$$$$
10 \text {. }
$$$$
0 \text {. }
$$

0 .

(a) Waterial required to produce $25 \mathrm{GW}(\mathrm{p})$. 
TABLE 14. "A" Materials (Sensitivity Cases)

\begin{tabular}{|c|c|c|c|c|c|c|c|}
\hline Factors & $\begin{array}{l}\text { Bulk(a) } \\
\text { Material } \\
\text { Usage MT } \\
\end{array}$ & $\begin{array}{c}\% \text { Supply } \\
\text { as } \\
\text { Byproducts }\end{array}$ & $\begin{array}{l}\text { Production } \\
\text { Growth } \\
\text { Rate - } 1990 \\
\end{array}$ & $\begin{array}{l}\text { Maximum } \% \\
\text { System } \\
1 \text { Year } \\
\text { World } \\
\end{array}$ & $\begin{array}{l}\text { \% From } \\
\text { One } \\
\text { Nation } \\
\text { Non-US } \\
\end{array}$ & $\begin{array}{c}\text { Present } \\
\text { Costs } \\
\text { in } \$ / \mathrm{kW} \\
\end{array}$ & $\begin{array}{c}\text { Net } \\
\text { Import }\end{array}$ \\
\hline Threshold Levels & & 50 & $10 . \%$ & 10 & 35 & 50 & 50 \\
\hline
\end{tabular}

Indium Phosphide/Cadmium Sulfide

Case 1: 15\% Efficiency

\section{Indium}

Phosphine 99.999

Indium-Tin Oxide

Cadmi um Sulfide

Case 2: Tin Oxide, 10\% Efficiency

号

Indium

Phosphine 99.999

Cadmi um Sulfide

Cadmi um Telluride Backwall

$\begin{array}{rc}8079 . & 100 .{ }^{*} \\ 2788 . & 0 . \\ 17250 . & 0 .\end{array}$

Case 1: 15\% Efficienty

Indi um

Tellurium

Indium-Tin 0xide

Cadmi um Telluride

Cadmium Sulfide

Case 2: Tin 0xide, 10\% Efficiency

Tellurium
Cadmium Telluride
Cadmi um Sulfide

7064.
13286.
17250

7064.
13286.

17250 .

$100{ }^{*}$
0.
0.
0.

0 .

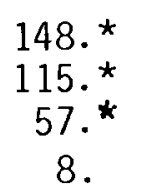

202. *

162.*

9.
91.*
$65 . *$
82. *

82.*

20.

93. *

73. *

$27 . *$

20.

10.

10.

10 .

79. *

14.

8.

11.

20. 109.*

10. 21 .

10.

17.

0 .

0 .

(a) Material required to produce $25 \mathrm{GW}_{(\mathrm{p})}$. 
TABLE 14. "A" Materials (Sensitivity Cases) (Cont'd)

\begin{tabular}{|c|c|c|c|c|c|c|c|}
\hline Factors & $\begin{array}{l}\text { Bulk (a) } \\
\text { Material } \\
\text { Usage MT } \\
\end{array}$ & $\begin{array}{c}\% \text { Supply } \\
\text { as } \\
\text { Byproducts }\end{array}$ & $\begin{array}{l}\text { Production } \\
\text { Growth } \\
\text { Rate }-1990 \\
\end{array}$ & $\begin{array}{l}\text { Maximum \% } \\
\text { System } \\
1 \text { Year } \\
\text { World } \\
\end{array}$ & $\begin{array}{l}\text { From } \\
\text { One } \\
\text { Nation } \\
\text { Non-US } \\
\end{array}$ & $\begin{array}{c}\text { Present } \\
\text { Costs } \\
\text { in } \$ / \mathrm{kW}\end{array}$ & $\begin{array}{c}\text { Net } \\
\text { Import } \\
\end{array}$ \\
\hline Threshold Levels & & 50 & $10 . \%$ & 10 & 35 & 50 & 50 \\
\hline
\end{tabular}

Zinc Phosphide

Case 1: 15\% Efficiency

Zinc Phosphide

5483.

0 .

39 . *

$71 . *$

10.

2.

0 .

Cadmium Selenide Photoelectrochemical

Case 1: $7 \%$ Efficiency

$\stackrel{\oplus}{\omega}$

\begin{tabular}{|c|c|c|c|}
\hline Cobalt & 381014 . & $100 *^{\star}$ & 20. \\
\hline Class, Soda lime & 13187500 . & 0 & 3 \\
\hline Indi um & 515. & $100 *^{*}$ & 16 \\
\hline Selenium & 7357. & $100 . *$ & 10 \\
\hline idium-Tin 0xide & 644 . & 0 . & $61 . *$ \\
\hline Cobalt Sulfate & 2072368 . & 0 . & 1535. \\
\hline
\end{tabular}

Case 2: Substitute graphite counter electrode, cadmium-selenide-telluride active layer, tin oxide transparent conducting layer, thinner glass encapsulant, 0.125 inches thick, $10 \%$ efficiency.

Selenium

Tellurium

Glass, Soda lime

2735 .

4550000 .

$100 . *$

0 .
$14 . *$

$59 . *$
$52 . *$
2.
$48 . *$
$28 . *$
$83 . *$
42. *

5.

20.

$37 . *$

10.
672.*

179. *

7.

12.

8.

1349.*

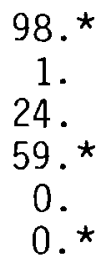

24.

59 *

0 . *

(a) Material required to produce $25 \mathrm{GW}(p)$. 


\section{TABLE 15. "B" Bulk Materials (Baseline Cases)}

\begin{tabular}{|c|c|c|c|c|c|}
\hline 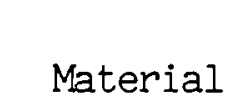 & $\begin{array}{c}\text { Indium Phos/ } \\
\text { Cad Sul }\end{array}$ & $\begin{array}{l}\text { Cadmium } \\
\text { Telluride }\end{array}$ & $\begin{array}{c}\text { Zinc } \\
\text { Phosphide }\end{array}$ & $\begin{array}{l}\text { Cadmium } \\
\text { Selenide }\end{array}$ & $\mathrm{Cu}, \mathrm{In}, \mathrm{Se}$ \\
\hline
\end{tabular}

Beryllium

Cadmium

Petroleum Coke

Ferromanganese

Tin

Zine

Fluorspar

Sodium Sulfide

Hydrochloric Acid

Silicon (SEG)

Silicon Monoxide

$\begin{array}{ll}\text { B } & \\ \text { B } & \text { B } \\ \text { B } & \text { B } \\ \text { B } & \text { B } \\ \text { B } & \text { B } \\ \text { B } & \text { B } \\ \text { B } & \text { B }\end{array}$

B
B
B
B
B
B

$B$
$B$
$B$
$B$
$B$
$B$

$\mathrm{B}$
$\mathrm{B}$
$\mathrm{B}$
$\mathrm{B}$

B
B
B
B
B
B
B

B

B

B

B

B

B

B

B

"B" Raw Materials (Baseline Cases)

\begin{tabular}{|c|c|c|c|c|c|}
\hline Material & $\begin{array}{l}\text { Indium Phos/ } \\
\text { Cad Sul } \\
\end{array}$ & $\begin{array}{l}\text { Cadmium } \\
\text { Telluride } \\
\end{array}$ & $\begin{array}{c}\text { Zinc } \\
\text { Phosphide } \\
\end{array}$ & $\begin{array}{l}\text { Cadmium } \\
\text { Selenide }\end{array}$ & $\begin{array}{l}\text { Cu, In, Se } \\
\text { /Cad Sul }\end{array}$ \\
\hline Bauxite & B & B & B & B & B \\
\hline Chromite & B & B & & B & B \\
\hline Fluorspar Ore & B & B & B & B & B \\
\hline Manganese Ore & B & B & B & B & B \\
\hline Tin Ore & B & B & & B & \\
\hline Zinc Ore & B & B & B & B & B \\
\hline Zine Byproducts & $B$ & B & & B & B \\
\hline Bertrandite & B & & & & \\
\hline Nickel Ore & & & & B & B \\
\hline Petroleum & B & B & B & B & B \\
\hline
\end{tabular}


TABLE 16. Mixed Scenario "A" Bulk Materials

\begin{tabular}{|c|c|c|c|c|c|c|c|}
\hline Factors & $\begin{array}{l}\text { Bulk } \\
\text { Material } \\
\text { Usage MT } \\
\end{array}$ & $\begin{array}{l}\begin{array}{l}\% \text { Supply } \\
\text { as } \\
\text { Byproducts }\end{array} \\
\end{array}$ & $\begin{array}{l}\text { Production } \\
\text { Growth } \\
\text { Rate - } 1990 \\
\end{array}$ & $\begin{array}{l}\text { Maximum \% } \\
\text { System } \\
1 \text { Year } \\
\text { World } \\
\end{array}$ & $\begin{array}{l}\% \text { From } \\
\text { One } \\
\text { Nation } \\
\text { Non-US } \\
\end{array}$ & $\begin{array}{l}\text { Present } \\
\text { Costs } \\
\text { in } \$ / k W \\
\end{array}$ & $\begin{array}{c}\text { Net } \\
\text { Inport } \\
\end{array}$ \\
\hline Threshold Levels & & 50 & $10 . \%$ & 10 & 35 & 50 & 50 \\
\hline $\begin{array}{l}\text { Cobalt } \\
\text { Indium } \\
\text { Selenium } \\
\text { Tellurium } \\
\text { Phosphine } 99.999 \\
\text { Indium Tin 0xide }\end{array}$ & $\begin{array}{r}53342 . \\
2938 . \\
2309 . \\
1413 . \\
558 . \\
450 .\end{array}$ & $\begin{array}{l}100 . * \\
100 . * \\
100 . * \\
100 . * \\
0 . \\
0 .\end{array}$ & $\begin{array}{c}6 . \\
74 . * \\
6 . \\
10 .^{*} \\
49 . * \\
43 . *\end{array}$ & $\begin{array}{l}13 . \star \\
84 . * \\
11 . * \\
42 . * \\
35 . * \\
77 . \star\end{array}$ & $\begin{array}{l}42 . * \\
20 . \\
37 . \star \\
21 . \\
10 . \\
10 .\end{array}$ & $\begin{array}{l}94 . * \\
40 . * \\
4 . \\
2 . \\
4 . \\
6 .\end{array}$ & $\begin{array}{l}98 . * \\
24 . \\
59 . * \\
53 . * \\
0 . \\
0 .\end{array}$ \\
\hline $\begin{array}{l}\text { Zinc Phosphide } \\
\text { Cadmium Telluride } \\
\text { Cobalt Sulfate } \\
\text { Cadmium Sulfide }\end{array}$ & $\begin{array}{r}1645 . \\
2657 . \\
290132 . \\
8621 .\end{array}$ & $\begin{array}{c}0 . \\
0 . \\
100 . * \\
0 .\end{array}$ & $\begin{array}{c}14 . \star \\
3526 . \star \\
218 . \star \\
7 .\end{array}$ & $\begin{array}{r}42 .{ }^{\star} \\
100 .^{\star} \\
94 . \star \\
16 . *\end{array}$ & $\begin{array}{l}10 . \\
10 . \\
42 . * \\
10 .\end{array}$ & $\begin{array}{c}0 . \\
64 . * \\
189 . * \\
8 .\end{array}$ & $\begin{array}{l}0 . \\
0 . \\
98 . * \\
0 .\end{array}$ \\
\hline
\end{tabular}

(1) This cost is an average of all the cells considered and therefore must be interpreted with care. For instance, if only $20 \%$ of the cells use a given material, then the $\$ / K w$ would actually be five times as high for those cells (i.e., the $20 \%$ ). 
layer thicknesses wherever possible, to substitute tin oxide for indium-t in oxide and to recycle the lost indium.

Selenium and tellurium are still "A" materials because their usage in photovoltaics will represent a large portion of each materials annual production. The discussions of these materials under the cadmium telluride and cadmium selenide photoelectrochemical cell still apply at 5 GW of cells online.

Phosphine $99.999 \%$ is still an "A" material because of the large portion of phosphine production used by photovoltaics. Since phosphine is currently produced in small quantities, achieving a $49 \%$ production growth rate should be rather easy.

Cadmium sulfide continues to be classified as an "A" material because photovoltaics will consume $16 \%$ of the wor'd's cadmium sulfide production in one year. Reduction in the thickness of the cadmium sulfide layers should alleviate this problem.

Zinc phosphide is currently produced in insufficient quantities to meet the needs of photovoltaics and is still classified as an "A" material. However, zinc phosphide production facilities located at the cell fabrication site should alleviate these problems.

Beryllium, ferromanganese, fluorspar, tin, and zinc, are "B" materials since large quantities of these materials are imported. However, these materials are used in small quantities by photovoltaics and will not present availability or cost problems.

Cadmium, petroleum coke, hydrochloric acid and sodium sulfide are "B" materials since they are produced as byproducts.

Silicon (SEG) is a "B" material since its usage in photovoltaics will require a $20 \%$ world production growth rate. Since silicon (SEG) is currently produced in sma11 quantities; a $20 \%$ production growth rate should be easy to attain. 
The mixed scenario (Table 16) has almost all of the problem materials identified in the individual baseline cases (at 25 GW online) with 10 "A" materials. Although the severity of each material problem is reduced in the mixed scenario, the number of problem materials that photovoltaics has to be concerned with increases. 



\section{FABRICATION PROCESS EFFICIENCY AND MATERIAL RECOVERY DETAILS}

Processes described in this section include planar reactive deposition, the related processes of screen printing, brush technique and painting and the close spaced vapor transparent process. Process efficiency numbers assume an $80 \%$ packing density of cells on the substrate. All other deposition processes have already been discussed (R. L. Watts et al. 1979)

Screen Printing, Brush Technique, Painting

Screen printing, the brush technique and painting are similar from a process efficiency point of view. Process efficiencies are near $80 \%$ since all material (material suspended in organic binder and flux) not deposited on the substrate is returned to the storage vessel and reused. To obtain the final layer composition once the paste has been deposited, the organic binder is vaporized or sublimed off by heat treatment. Layers deposited by screen printing and related techniques are usually thicker than layers of the same material deposited by other processes. Layers at least 20 to $25 \mathrm{~m}$ thick are needed to obtain wel1-defined edges. Losses, usually very smal1, occur during the cleaning of equipment. Material recovery is probably not important for this process because of its high efficiency.

Planar Reactive Deposition

In the planar reactive deposition (PRD) process, In is evaporated from a Knudsen cell and reacted with $\mathrm{PH}_{3}$ at the substrate to form InP. The process efficiencies for In usage and $P$ usage are therefore different. Process efficiencies also depend strongly on the relative areas of the substrate and substrate holder. Inefficient experimental PRD systems have process efficiencies near $1 \%$ for In and $5 \%$ for $P$, while production systems optimized for materials usage are estimated to have efficiencies near $40 \%$ for In and 25 to $35 \%$ for $P$. Materials losses occur on chamber walls, on unused portions of the substrate holder and as a result of In left in the crucible. Materials usage efficiency can be increased by depositing on larger substrates and closely packing substrates. Prospects for material recovery appear good. By strategic placement of shielding, much of the In is recoverable from chamber walls and substrate 
holder. $\mathrm{PH}_{3}$ is recoverable through the use of cold traps in the pumping line. If recycling is economically sensible, overall materials usage efficiency can be increased for both In and $P$. The economics of recycling repurification and reuse of In and $\mathrm{PH}_{3}$ have not been examined. Close-Spaced Vapor Transport (CSVT) Process

The CSVT process materials usage efficiency depends to a large extent on substrate size and packing density. Research CSVT systems have process efficiencies near $40 \%$ and production systems optimized for materials usage efficiency are expected to have efficiencies in the range of 50 to $60 \%$. Material usage efficiency can be increased by using larger substrates or using close packing density of substrates. Material is lost through deposition on chamber walls and on unused portions of the substrate holder. Material not deposited on the substrate is recoverable by collecting it on shielding strategically located in the reactor and on the substrate holder. Prospects for material recovery thus appear excellent. If recycling is economically feasible, overall materials usage efficiency can be increased beyong 65 or 75\%. The economics of material recovery and purification have not been examined.

Plasma Deposition Process

The plasma deposition process is similar to the glow discharge decomposition process previously discussed for silicon disposition from silane, $\mathrm{SiH}_{4}$. For production deposition of carbon from acetylene, $\mathrm{C}_{2} \mathrm{H}_{2}$, the plasma deposition process efficiency is expected to be $35 \%$. 


\section{REFERENCES}

"Domestic Policy Review of Solar Energy". U.S. Department of Energy, TID28835, Washington, D.C., 1978.

U.S. Bureau of Mines. 1975. Mineral Facts and Problems. U.S. Government Printing Office, Washington, D.C.

U.S. Geological Survey. 1973. Professional Paper 820. U.S. Government Printing Office, Washington, D.C.

Watts, R. L., et al. 1980. The Evaluation of Critical Materials for Five Advanced Design Photovoltaic Cells with an Assessment of Indium and Gallium. PNL-3319, Pacific Northwest Laboratory, Richland, WA.

Watts, R. L., et a1. 1979. Quarterly Progress Report on the Evaluation of Critical Materials for Photovoltaic Cel1s. PNL-3234, Pacific Northwest Laboratory, Richland, WA. 


\section{APPENDIX A \\ ADDITIONS TO THE CMAP DATA BASES}

The following are the additions made to the various CMAP data bases. The earlier version of this data base is included in Appendix A of Watts, R. L., et a1. 1980. The Evaluation of Critical Materials for Five Advanced Design Photovoltaic Cells With an Assessment of Indium and Gallium. PNL-3319, Pacific Northwest Laboratory, Richland, Washington. 
Bulk Material: Zinc Phosphide

Bulk Materials

Zinc

Phosphorous

Amount (MT)
.7600
.2400

Bulk Material: Zinc Sulfide

Bulk Materials

Zine

Sulfuric Acid

HJydrogen Sulfide 99.9

Amount (MT)

.7008

1.0066

.3498

Bulk Material: Cadmium Tellurdie

Bulk Materials

Cadmium

Tellurium

Amount (MT)

.4682

.5317

Bulk Material: Cobalt Sulfate

Raw Materials

Water

Bulk Materials

Sulfuric Acid

Water

Cobalt Oxide

Amount (MT)

.6915

Amount (MT)

.6325

.1160

.4837

Bulk Material: Cobalt Oxide

Bulk Materials

Nitric Acid

Cobalt

Amount (MT)

.4120

.3801

Bulk Material: Sodium Sulfide

Raw Materials

Barite

Coal

Sodium Carbonate

Amount (MT)

4.6012

1.1142

1.2581

Bulk Material: Tin Oxide

Bulk Material

Tin

Amount (MT)

.788

Bulk Material: Beryllium

Raw Materials

Bertrandite

Bulk Materials

Sulfuric Acid

Ammonia

Water

Magnesium

Amount (MT)

7.3429

12.0919

8.3987

4.4422

2.6977

Percent

5.00

95.00

Aluminum 


\section{BUIK MATERTAL DATA SUMMARY}

\begin{tabular}{|c|c|c|c|c|c|c|c|c|}
\hline $\begin{array}{l}\text { Material } \\
\text { Name }\end{array}$ & $\begin{array}{l}\text { \& Supplied } \\
\text { As } \\
\text { By Product }\end{array}$ & $\begin{array}{c}\text { World } \\
\text { Consumption } \\
1976 \\
\text { MI } \\
\end{array}$ & $\begin{array}{l}\text { World } \\
\text { Consumption } \\
2000 \\
\text { MT } \\
\end{array}$ & $\begin{array}{l}\text { \& From } \\
\text { Irargest Non } \\
\text { US Country }\end{array}$ & $\begin{array}{r}\text { Price } \\
\text { \$/MT }\end{array}$ & $\begin{array}{c}\text { Net } \\
\text { Percent } \\
\text { Imported }\end{array}$ & $\begin{array}{l}\text { U.S. } \\
\text { Consumption } \\
1976 \\
\text { MT } \\
\end{array}$ & $\begin{array}{c}\text { U.S. } \\
\text { Consumption } \\
2000 \\
\mathrm{MT} \\
\end{array}$ \\
\hline Zinc Phosphide & 0. & 167. & 406 & 10. & $\$ 7387$ & 0 . & 100. & 203. \\
\hline Zinc Sulfide & 0 . & 453. & 1390. & 20 . & $\$ 11,025$ & 0 . & 272 . & 697. \\
\hline Cadmium Telluride & 0. & 1.04 & 1.67 & 10 . & $\$ 600,000$ & 0 & .520 & .830 \\
\hline Cobalt Sulfate & 0. & 1440 . & 3610 . & 42 . & $\$ 16,272$ & 98. & 862. & 1940. \\
\hline Sodium Sulfide & 100 . & 545,000 & $1,330,000$ & 0 . & $\$ 400$ & 0 . & 327,000 & 665,000 \\
\hline Tin Oxide & 0 . & 1728 . & 2779 & 30 . & 20,200 & 40. & 500 . & 634.9 \\
\hline $\begin{array}{l}\text { Hydrogen Sulfide } \\
99.9\end{array}$ & 0. & 1100 & 2820 . & 10 . & 2866 & 0 . & 550 & 1410 \\
\hline Beryllium & 0 . & 174 . & 435.8 & 15. & 176,400 . & 57. & 46. & 112.6 \\
\hline
\end{tabular}


HAW MATERIAI, DATA SUMHURY

$01 / 24 / 80$

MATERIAL

$\begin{array}{ccccccc}\text { WORLD } & \text { WORLD } & \text { PRICE } & \text { RAW } & \text { RAW } & \chi & \chi \text { RESERVES } \\ \text { CONSUMP } & \text { CONSUNP } & \text { S/MT } & \text { RESERVRS } & \text { RESOURCES } & \text { LARGFST } & \text { TOP } 3\end{array}$

WORLD

COUNTRY COUNTRIES

WORLD
MT

NTT

MT MT

MT

-ח-

Bertrandite 1160. 2905. 26460. 2.54+06 7.38+06

17

43

\begin{tabular}{l} 
NET \\
PERCENT \\
IMPORTED \\
\hline
\end{tabular}

U.S. U.S

CONSIUMP CONSUIMP RESERVES RESOURCPS

1976

U.S.

U.S.

57

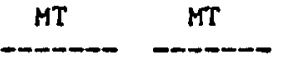

MT

MT 


\section{DISTRIBUTION}

No. of

Copies

OFFSITE

27 DOE Technical Information Center

A. A. Churm

DOE Patent Division

9800 South Cass Avenue

Argonne, Illinois 60439

2 Stephen R. Nagy

Solar Energy Research Institute

1617 Cole Boulevard

Golden, Colorado 80401

Satyen Deb

Solar Energy Research Institute

1617 Cole Boulevard

Golden, Colorado 80401

Kim Mitchell

Solar Energy Research Institute

1617 Cole Boulevard

Golden, Colorado 80401 .

David Benson

Solar Energy Research Institute

1617 Cole Boulevard

Golden, Colorado 80401

J. Richard Burke

Solar Energy Research Institute

1617 Cole Boulevard

Golden, Colorado 80401

Bryon Jackson

Solar Energy Research Institute

1617 Cole Boulevard

Golden, Colorado 80401

31 Stephen R. Nagy

Solar Energy Research Institute PV Analysis \& Evaluation Branch 1617 Cole Boulevard

Golden, Colorado 80401
No. of

Copies

OFFSITE

Will iam Wallace

Solar Energy Research Institute 1617 Cole Boulevard

Golden, Colorado 80401

Solar Energy Research Institute Subcontracts Branch

Contract Number DS-9-8137-1

1617 Cole Boulevard

Golden, Colorado 80401

Ron R. Teeter

Battelle Columbus Laboratory

505 King Avenue

Columbus, Ohio 43201

William Jamieson

Battelle Columbus Laboratory

505 King Avenue

Columbus, Ohio 43201

Stephen Day

DuPont Corporation

Photo-Products Division

Willmington, Delaware 19898

Robert Ferber

Jet Propulsion Laboratory

4800 Dak Grove Drive

Building 506

Pasadena, California 91103

K. W. Koliwad

Jet Propulsion Laboratory

Building 506

4800 Oak Grove Drive

Pasadena, California 91103

J. R. Loebenstein

Department of Interior

Bureau of Mines

Washington, D.C. 20585 
PNL -3710

UC-63

No. of

Copies

\section{OFFSITE}

Paul Moskowitz

Building 475

Brookhaven National Laboratories

Upton, New York 11973

Richard Stirn

Jet Propulsion Laboratory

4800 Oak Grove Drive

Mail Stop 512103

Pasadena, Cal ifornia 91103

Dr. Alan Postlewaite

Department of Energy

MS 5G033 Forrestal Building

Washington, D.C. 20545

Allen White

Northeast Solar Energy Center

70 Memorial Drive

Cambridge, Massachusetts 02142

G. Reid Bowlby

Noranda Sales Corp., Ltd.

P. 0. Box 45

Commerce Court West

Toronto, Ont., Canada M5L 1B6

Casa Moret

Commercial Development

Ethyl Corp.

Ethyl Tower

451 Florida

Baton Rouge, LA 70801

Reid Mickelson

Boeing Aerospace Company

P.0. Box $3999 \mathrm{~m} / \mathrm{s} 88-43$

Seattle, Washington 98166
No. of

Copies

ONSITE

DOE Richland Operations Office

H. E. Ransom

17 Pacific Northwest Laboratory

R. W. Watts

W. W. Pawlewicz

W. E. Gurwe 11

L. W. Long

S. A. Smith

C. H. Bloomster

D. E. Deonigi

Economics Library (3)

Technical Information (5)

Publishing Coordination (2) 